Historic, Archive Document

Do not assume content reflects current scientific knowledge, policies, or practices. 


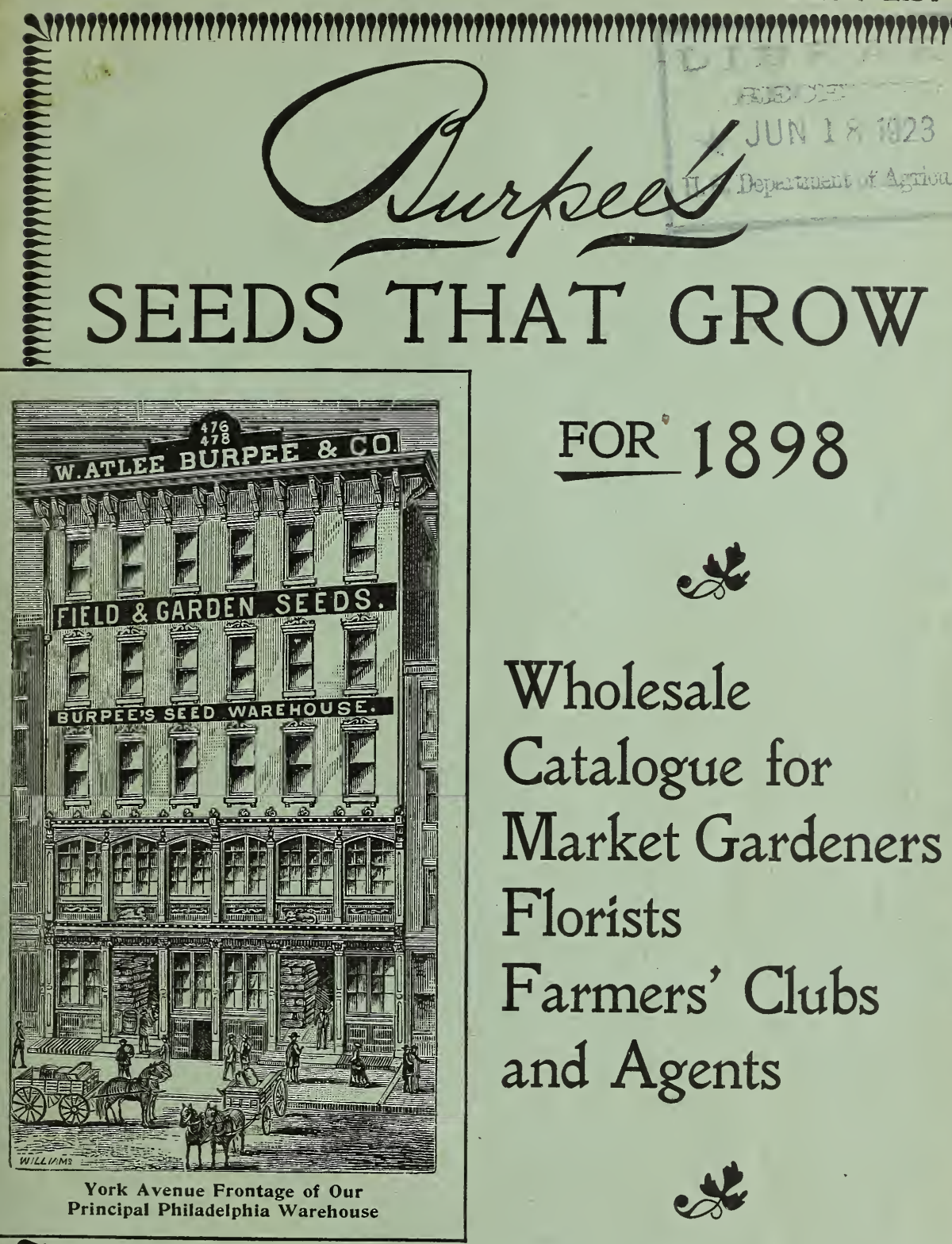

FOR 1898

Wholesale

Catalogue for

Market Gardeners

Florists

Farmers' Clubs

and Agents

W. Atlee Burpee \& Co.

$\begin{gathered}\text { Offices and } \\ \text { Seed Warehouse }\end{gathered}$
$\begin{aligned} & \text { Nos. } 475 \text { and } 477 \text { N. Fifth St. } \\ & \text { Nos. } 476 \text { and } 478 \text { York Ave. }\end{aligned}$
PHILADELPHIA

Seed Gardens at FORDHOOK FARM, Doylestown, $\mathrm{Pa}$. 


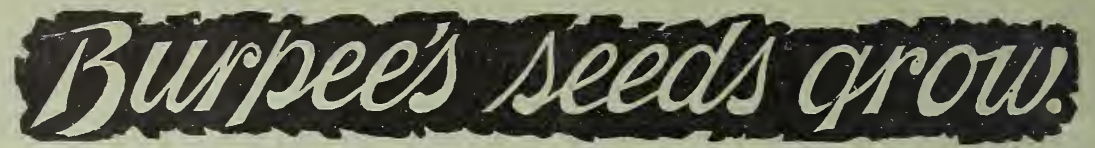

At our famous FordHook FARM, in Bucks County, thirty-two miles from Philadelphia, we conduct, each year, the most extensive Trial Grounds in America. We travel, also, among our growers throughout America and Europe, personally inspecting the crops growing on contract.

We buy but few seeds in the open market,-although we could purchase at prices lower than we pay for our own crops, which are grown from selected stocks and carefully "rogued." Briefly,-both in the seeds grown by ourselves and by our contract growers, - we seek not the cheapest but the BEST.

Our business was originally established and has been conducted for many years on the lines of supplying only the BEST SEEDS that grow direct to market gardeners and private planters. We have sought the trade of intelligent buyers, who could appreciate quality in seeds and were willing to pay a fair price for the best it is possible to produce. By keeping quality always our first aim, and at the same time being content with a small margin of profit, we have succeeded in building up what is now acknowledged to be the largest mail trade in the United States.

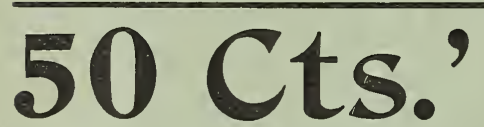

\section{Worth of Seeds EXTRA} will be allowed on each ONE DOLLAR sent for Seeds in Retail PACKETS.

The retail prices "per packet" given in this catalogue are the same as in BURPEE'S FARM ANNUAL for 1898 , and are subject to a discount of thirty=three and one=third per cent. This same discount applies to our popular twenty-five cent collections of "SEEDS FOR THE MILLION" (as advertised on page 40), and allows a handsome profit to those who get up clubs for BURPEE'S SEEDS.

\section{"LESS 33\% $\frac{\mathrm{T}}{3}$ PER CENT. ON SEEDS IN PACKETS."}

After making out your order from this wholesale catalogue, figure up the total amount of seeds in retail packets-write statement as above-and deduct one-third from the total amount of seeds in retail packets. This discount does not apply to Trade Packets of Flower Seeds, which, like all the prices of seeds by weight or measure, are net,-subject to no discount.

\section{SEEDS BV MAIL, Please remember that prices in this catalogue do NOT} at these prices are ordered to be sent by mail, $8 \mathrm{cts}$. per lb., or $15 \mathrm{cts}$. per quart, extra must be remitted in addition to the price of the seed, to cover cost of postage.

Every year some purchasers order seeds at freight and express prices to be sent by mail. It is impossible to open accounts for small balances, and when seeds are ordered to be mailed at bulk prices, without an accompanying remittance to cover cost of postage, we must reduce the quantity to correspond with remittance.

\section{BURPEE'S SEEDS are the lowest=priced GOOD SEEDS.}

Estimates by MAII. While the prices quoted, both by the pound and bushel, are very low Estinates by for the quality, yet some Market Gardeners, Farmers' Clubs, and Canners require a large quantity of seed, and on the entire order we can frequently make a better price than we could afford on smaller orders. Therefore, before being induced by lower prices to place your order elsewhere, please write to us, giving a list of quantities and varieties required, when we will send an estimate by return mail.

HOW TO ORDER. Please be careful to sign your name, post-office, county, and State on each and every letter sent us. Cash should accompany the order. Money can be sent safely either by post-office order, bank draft, express order, or the cash by registered letter. We accept clean postage stamps the same as cash.

Every postmaster is obliged by law to register a letter on payment of eight cents, in addition to postage, and then you will receive our receipt for the letter by return mail. We are responsible for the safe receipt of remittance by any of the above methods. The efficiency of the Post-Office Department is such, however, that a letter is seldom lost.

C. O. D. Orders of $\$ 25.00$ or less will be sent collect on delivery, by express, if $\$ 2.00$ is sent with C. O. D. the order as a guaranty of good faith. There is little need for C. O. D. shipments, however, as even where we are not known personally you can ascertain our responsibility by consulting the Mercantile Agencies at any bank. Goods can NOT be sent C. O. D. by freight, and, of course, on heavy orders it is cheaper to ship by freight.

PLEASE WRITE each item of your order on a separate line, and carry out the prices. Also please keep a copy of your order, with which to "check off" the seeds when received, to be sure that you receive just what you ordered. We seldom make mistakes, but when we do, want to be notified immediately, so that they can be corrected. Kindly write any questions, requiring answers, separately from the order.

Letters reach us safely if addressed simply-BURPEE, Philadelphia.

W. ATLEE BuRPEE \& CO., PhiladelPhia, Pa. 


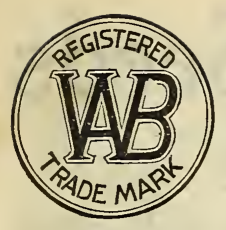

\section{To Market Gardeners and Florists.}

The relations of the Planter to his trusted Seedsman are more intimate than those of the buyer and seller in any other line of business. With other goods the buyer can judge largely of quality by the sample, BUT with SEEDS the purchase is altogether a matter of confidence.

It is impossible to distinguish by examination the difference between the seed of Cauliflower, Cabbage, or Turnip, much less to tell the relative value of the different samples. As an illustration, the plumpest, finest-looking Cabbage seed is the English grown, and it costs less than half the price of the American seed. Then, too, the brightest and best-looking Tomato seed may be saved without any selection by canning establishments at little expense. And we could mention many other instances to show that you must trust some one implicitly in your purchase of seeds.

\section{WHY NOT BE SURE?}

Good crops can be raised only from good seeds.

Burpee's Seeds are the very best seeds that grow, and they cost no more, if ordered by mail direct from Philadelphia, than many largely advertised "cheap" seeds which in most cases would be dear at any price. Your local merchant may be a perfectly honorable, straightforward man, but he cannot know seeds, nor the value of them, and must take the "say-so" of the house from which he buys. As explained on the next page, Burpee's Seeds cost too much for the dealer to handle, who has his eye mainly on an immediate and large profit.

\section{YOU TAKE NO RISK}

in ordering Burpee's Seeds direct by mail, and you have the great advantage of being able to select just what you require from this Complete Catalogue of all the Best Seeds. It is, of course, impossible for any local merchant to carry a full line, while it is equally impossible for any other seedsmen to supply our unequaled new exclusive introductions of 1898, as, with the exception of BURPEE's PINK CUPID, these have not been offered to the trade. Every one who would keep abreast of the times in Horticultural Progress will want some of our ExcLusive NoveLties in Vegetables or Flowers.

\section{LOW PRICES Again for 1898. By reducing the cost of our} year, we were able to offer prices lower than ever before. Again we have harvested abundant crops and maintain these reduced prices, notwithstanding the general advance in farm products and the evident return of prosperity for agriculture, "the basis of all wealth." Better seeds cannot be had at any price, while nowhere High=Grade TESTED SEEDS of equal quality can be bought for less money.

It is easy to order Seeds by MAIL. All you have to do, is to make out a list of the seeds wanted, attach the prices to each, deducting one=third from the total of seeds in retail packets, and remit by money order, draft, or registered letter We assume all risk, - that is, we guarantee that the seed will arrive promptly and in good condition.

We guarantee, further, that the seed shall be first-class, true to name and of strong vitality, in so far, that should any prove otherwise we will refund the price paid. Further than this we cannot warrant, but this is a satisfaction given by few other seedsmen, and must convince even those who have never dealt with us of the confidence we have in our ability to supply only the Best Seeds that grow"Tried and True." If you have not received a copy already, you are requested to write at once for BURPEE'S FARM ANNUAL FOR I898, pronounced "the leading American Seed Catalogue."

CITY WAREHOUSE:

475 and 477 North Fifth St.,

476 and 478 York Avenue.

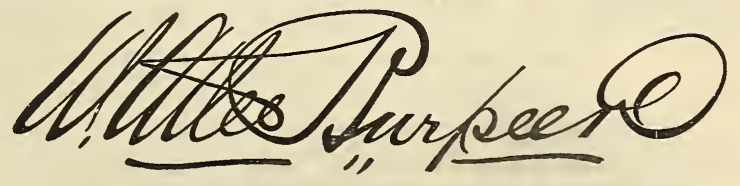

PHILADELPHIA, PA. 


\section{Burpee's Genuine Seeds are sold only in sealed packages.}

Seeds of the best quality cost very much more to produce than do seeds of the ordinary commercial grade. And yet many merchants, having little or no knowledge of the value of High=Class Seeds, purchase their supplies wherever they can be obtained the cheapest. Again, there are stores in every village that handle only boxes of seeds, left on commission. We receive letters like the following:

\footnotetext{
"Will you please send me a box of your Vegetable, also a box of your Flower Seeds on Commission? I have been handling _—'s Vegetable and _—'s

Flower Sceds, but my customers tell me that your seeds are much better."
}

In reply to such inquiries we write that we never send seeds on commission. We sell outright only. Because our seeds cost so much more to produce than the average grades handled generally in the trade, there are comparatively few merchants who are willing to pay the prices charged by us,-they say the margin of profit is too small. An examination of the prices quoted will show, however, that by dealing direct with the planter we are able to sell BURPEE'S SEEDS practically at the same prices as the so-called " cheap seeds,"-BUT we are not able to quote wholesale prices nearly so low as many of our competitors, who at retail may charge the same as we do.

It has been brought to our notice that some merchants will buy a bill of seeds from us, obtain copies of our catalogues and show cards, and then purchase a portion of their supplies from other seedsmen, who, growing "cheap seeds," can sell at much lower prices. In many cases planters who purchased from their local merchants, thinking that they were obtaining BURPEE'S SEEDS, got only a few of our seeds (perhaps in packets), and often the seeds bought by weight or measure were of inferior quality, falsely sold on our reputation, but for which we were not in any way responsible.

This deception was brought so prominently to our attention the past year that we debated seriously whether we should not decline altogether to sell BURPEE'S SEEDS at wholesale, and announce in 'THE FARM ANNUAL FOR 1898 that BURPEE'S SEEDS could be obtained ouly direct from Philadelphia. Further consideration, however, showed us that this would hardly be fair to the honorable mercliants who have been handling our seeds exclusively for years, and in whom we could place confidence. Therefore we decided upou the plan announced below:

\section{Hereafter we will sell Burpee's Seeds ONLY in sealed packages.}

Packets and ounces, in the Spangler Water-tight Bags, are sealed as heretofore, and bear, plainly printed, either our Name or Registered Trade=mark Monogram, protected by United States Letters Patent. Quarter pounds, pounds, pints, and quarts, done up in paper bags or cartons, will have pasted across the top a green label, worded as follows :

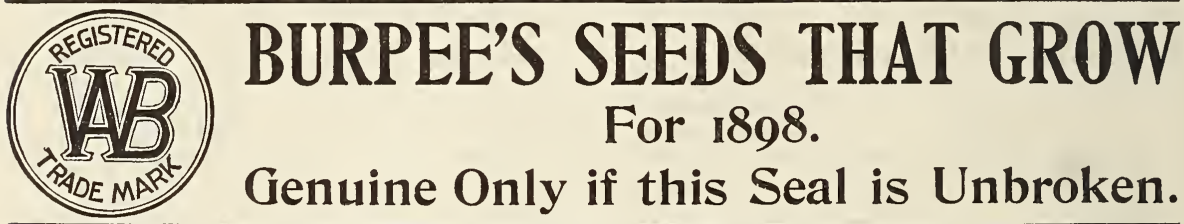

Seeds in Bulk, - that is, Peas, Beans, etc., by the peck or bushel, and large quantities of small seeds in bags, will have each sack sealed with our Trade Mark on a leaden seal.

This plan will be a protection to honest merchants from competition with other seeds claimed to be BURPEE'S SEEDS, and at the same time will be a guarantee to the purchaser.

Our Only Salesman is our annual Catalogue. We employ no travelers. While we are glad to have responsible parties get up clubs, we must caution both merchants and planters to trust no one not personally knoun to them.

Burpee's Farm Annual, The Leading American Seed Catalogue,

Shopping by Thil is both pleasant and profitable. From this Complete Catalogue of the Bist Shopping by 1 all SeEDs That Grow you can select your requirements, iu the quiet of your own home, and have your order filled as promptly as if you could call in person at our city warehouse.

Please read How To ORDER on second page cover, and rcmember that our prices include bags and boxes (where necessary), and delivery to any railroad or steaner in Philadelphia, but the purchaser pays transportation charges upon receipt.

NO ORDER IS TOO SMALL FOR US TO FILL. We bring this fact out prominently, because many planters finding that they needed a few packets, forgotten in their general order, have written us that they bought these from the commission "Box Seeds" at the village store, and the results have been unsatisfactory.

We accept postage stamps the same as cash, while silver wrapped in paper may be sent safely in a letter, so that you can order even one or two packets by mail. If at any time you do not recall our full address, please remiemiber that letters reach us addressed simply-

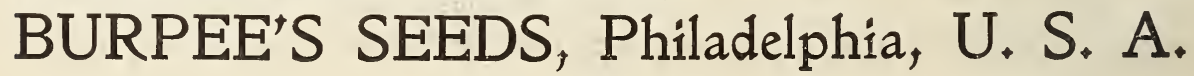




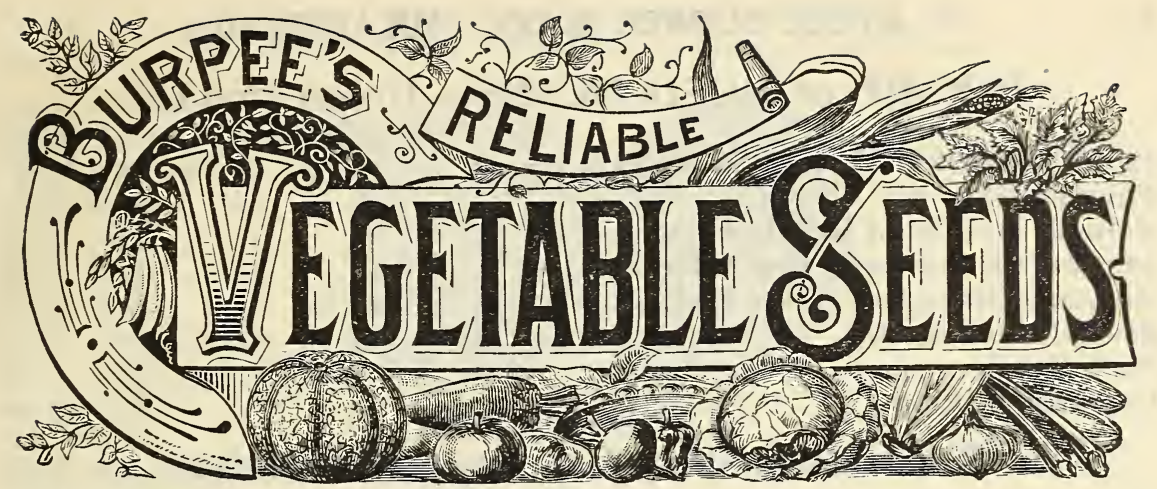

In the following pages we offer not only all the good STANDARD Vegetables, but also many choice NOVELTIES and SPECIALTIES. Varieties marked with our TRADE=MARK MONOGRAM were intro= duced first by us. We devote special care to the selection of stock seed and the "roguing" of our crops, so that we know positively that BURPEE'S SEEDS GROW, and are the BEST SEEDS that Grow. Every variety is tested each year at ForDHOOK FARM. We know that it is impossible to procure better seeds than those sold by us.

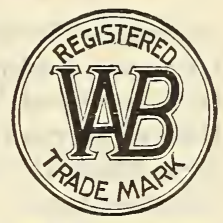
Seeds by Weight. Please remember that the prices quoted herein are net for Seeds by Weight. seeds by weight or measure, but that all vegetable seeds at prices " per packet" are subject to a discount of thirty=three and one=third per cent. See second page cover.

\section{Burpee Seeds are "Tried and True."}

The great development of the seed industry in America is nowhere better exemplified than on the large seed farm of IV. Atlee Burpee \& Co., at ForDHook,-located among the Bucks County hills in Pennsylvania, - a name now as familiar among seed growers and buyers as a household word. "Tried and True" is the motto carried out at Fordhook.

'Too much eredit cannot be given to Mr. W. ATLEe BurpeE, the head of the great Philadelphia firm, for the energy he has displayed and the capital he has expended in order to make the experiments carried on at this perfect model farm of the utmost value, not only to himself, but to the whole nation.-From The Florists' Exchange, New York, September 29, 1894.

\section{A YEAR'S WORK AT FORDHOOK FARM.}

This little book, written by E. J. WHEELOCK, lays before the reader, in an attractive manner, by the united efforts of pen and camera, an exact picture of our famous ForDHOOK FARM.

"Mr. Burpee would be only too glad if every one of the thousands upon thousands of the firm's customers from all over the globe could go to Doylestown and see ForDHOOK with their own eyes; but as this is a manifest impossibility with the larger proportion of them, this little book has been prepared as a sort of humble mirror which will reflect, at least, a feeble likeness of FORDHOOK and its doings to the uttermost parts of the earth, and make all peoples acquainted with the system and processes which have made this one of the greatest seed farms in the world, and the source of one of the most flourishing busin ess enterprises in the United States."-Extruct from the Author's Introduction to A YEAR's WORK AT FORDHOOK FARM.

Beautifully lliustrated. Mailed to any address for two 2 =cent stamps.

\section{ARTICHOKE.}

Large Green Globe. The standard, New Early Violet Campania. From Italy, .

\section{ASPARAGUS.}

Conover's Colossal. The standard, Barr's Mammoth. The Philadelphia favorite, Columbian Mammoth. Large white shoots, .

\begin{tabular}{|c|c|c|c|}
\hline Per Pkt. & Per Oz. & $1 / 4$ to. & Per fb. \\
\hline So IO & $\$ 020$ & $\$ 075$ & $\$ 250$ \\
\hline I 5 & 30 & I & 50 \\
\hline
\end{tabular}

350

ASPARAGUS ROOTS,-Conover's Colossal. One-year-old roots, 45 cts. per IOO; 80 cts. per IOO if by mail; $\$ 3.75$ per IOOO; two-year-old roots 45 cts. per IOO; $\$ 4.00$ per IOOO-sent by express at expense of purchaser.

BARR'S MAMMOTH and COLUMBIAN. Each: roots, one-year-old, 50 for $50 \mathrm{cts}$; $90 \mathrm{cts}$. per Ioo, by mail, postpaid. By express, at expense of purchaser, one-year old roots, 50 cts. per I00; 500 for $\$ 2.25$, or $\$ 4.00$ per Iooo. Two-year-old roots, by express, 60 cents per IOO; 500 for $\$ 2.75$, or $\$ 5.25$ per Ioog. 


\section{DWARF or BUSH BEANS,-Green Podded.}

Quart. 2 Quarts. 4 Quarts. Peck.

Bushel.

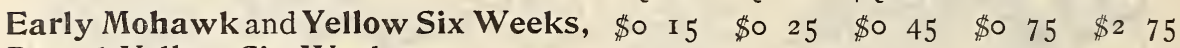

Round Yellow Six Weeks, . . . . . I $\quad \begin{array}{lllll}5 & 25 & 45 & 75 & 275\end{array}$

Refugee and China Red=Eye, each, . $\quad \begin{array}{llllll}\text { I } 5 & 25 & 45 & 75 & 275\end{array}$

Improved Extra Early Red Valentine, $\begin{array}{llllll}\text { I } 5 & 25 & 45 & 75 & 2 & 75\end{array}$

Burpee's Stringless Green Pod, . . $\quad 25 \quad 45 \quad 85 \quad$ I $50 \quad 550$

Blue=Podded Butter, . . . . . . $\quad 25 \quad 45 \quad 85$ I $50 \quad 550$

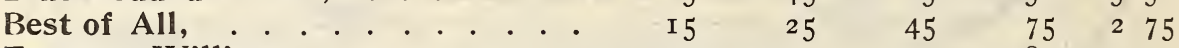

Emperor William, . . . . . . $\quad 20 \quad 30 \quad 50 \quad 8530$

BUSH BEANS,-Wax=Podded Varieties.

Burpee's Perfection Wax

Burpee's Saddle=Back Wax, . . . .

Golden=Eyed Wax,

Dwarf German Black Wax, ... .

New Prolific German Black Wax, .

Golden Wax,

Improved Rust=Proof Golden Wax, .

Keeney's Rustless Golden Wax, . .

Davis White Wax,

New Vineless Marrow, . . . . 20

Yosemite Mammoth Wax, . . . . 25

New Black=Eye Wax,

\section{Quart.} $\$ 0 \quad 25$

25
25
I 5
20
15
20
20
20
20
25
20

$\$ 0 \quad 40$
40
25
25
30
25
30
30
30
35
45
30

Peck.

Bushel.

$\$ 450$

$\begin{array}{rrrrrrr}40 & \$ 0 & 75 & \$ I & 25 & \$ 4 & 50 \\ 40 & & 75 & \text { I } & 25 & 4 & 50\end{array}$

$\begin{array}{lllll}25 & 45 & 75 & 275\end{array}$

$\begin{array}{lllll}25 & 45 & 75 & 2 & 75\end{array}$

$30 \quad 50 \quad 85 \quad 300$

$\begin{array}{lllll}25 & 45 & 75 & 2 & 75\end{array}$

$30 \quad 50 \quad 85 \quad 300$

$30 \quad 50 \quad 85 \quad 300$

$30 \quad 50 \quad 85 \quad 300$

3560 I $00 \quad 350$

$45 \quad 85$ I $50 \quad 575$

$30 \quad 50 \quad 90 \quad 325$

\section{BUSH BEANS,_Varieties for Shelled Beans.}

Goddard, or Boston Favorite,

White Marrowfat,

Prolific Tree Bean,

Burpee's Bush Lima,

Henderson's Bush Lima,

Thorburn, or Dreer's Bush Lima,

Jackson Wonder Dwarf Lima, .
Quart. $\quad 2$ Quarts. 4 Quarts. Peck.

Bushel.

$\$ 275$

275

300

550

400

450

400

\section{BEANS,-Pole or Climbing.}

Quart. 2 Quarts. 4 Quarts. Peck. Bushel.

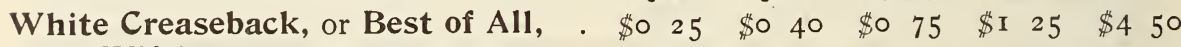

Lazy Wife's, . . . . . . . . . $\quad 25 \quad 45 \quad 75$ I $35 \quad 5$ ○

Burpee's Sunshine Wax, . . . . $30 \quad 50 \quad 90$ I $60 \quad 600$

Golden Cluster Wax, . . . . . . . $30 \quad 45 \quad 35$ I 35 co

Horticultural, or Cranberry, . . . $\quad 20 \quad 35 \quad 65$ I $10 \quad 400$

Southern Prolific, Kentucky Wonder, $\quad 20 \quad 40 \quad \begin{array}{llllll}75 & \text { I } & 25 & 4 & 50\end{array}$

Old Homestead (Improved Wonder), $\begin{array}{lllllll}25 & 45 & 80 & \text { I } & 35 & 5 & 00\end{array}$

White Dutch Case Knife, . . . . . $\quad 25 \quad 45 \quad 75 \quad$ I $35 \quad 500$

Horticultural Lima Pole Bean,. . . $\quad 25 \quad 40 \quad 65$ I $00 \quad 375$

Early Black Lima, . . . . . . . $25 \quad 45$

Willow Leaf Lima, . . . . . . . $\quad 25 \quad 45$

Small Lima, Carolina, or Sieva, . . $25 \quad 40$

Large White Lima, . . . . . . . . $\quad 25 \quad 45$

Challenger (Dreer's Improved Lima), $\quad 25$

Extra Early Jersey Lima, . . . . $\quad 25$

King of the Garden Lima, . . . . . 25

Ford's Mammoth Podded Lima, . . 25

85 I $50 \quad 5 \quad 50$

75 I $35 \quad 500$

70 I IO 400

$\begin{array}{lllll}75 & \text { I } 35 & 5 & 00\end{array}$

$\begin{array}{lllll}75 & \text { I } & 35 & 5 & 00\end{array}$

75 I $35 \quad 5$ ००

$80 \quad$ I $50 \quad 5 \quad 50$

$80 \quad$ I $50 \quad 550$

Each of the above, ro cents per packet, of two ounces. 


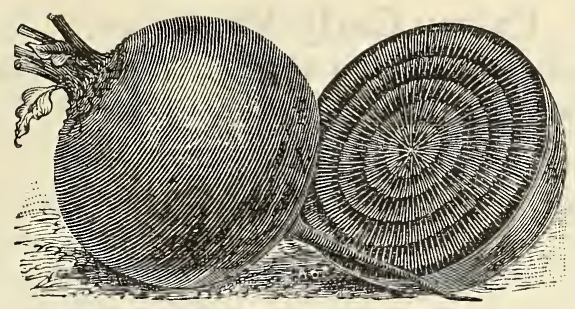

\section{GARDEN BEETS.}

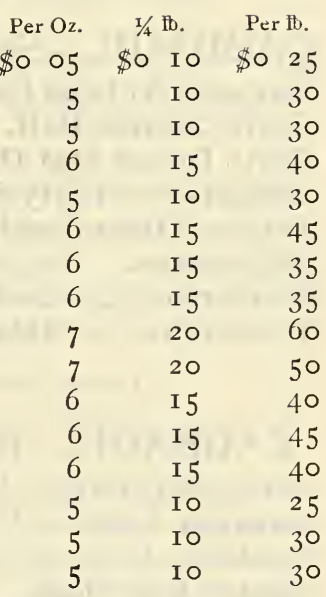

Early Blood=Red Turnip. The old stand-by, . . . . . \$० ०5 \$० I० \$० 25

Dewing's Improved Blood Turnip, . . . . . . . . . 5 io 30

Extra Early Egyptian. Flat bulbs; very early, . . . 5 5 $10 \quad 30$

Crosby's Egyptian. An improved strain, . . . . . . 6 I 6 I0

Bastian's Extra Early Red Turnip. A fine extra early, $\quad 5 \quad$ io 30

Burpee's Extra Early Turnip. Earlier and better, . . $6 \begin{array}{llll}5 & \text { I } 5 & 45\end{array}$

Edmand's Early Turnip. Quick-growing and fine, . . $\quad 6 \quad$ I $5 \quad 35$

Eclipse. One of the most popular round, early beets, . $\quad 6 \quad \begin{array}{lll}6 & \text { I } 5 & 35\end{array}$

True Dark Stinson. Extra early; very short tops, . . $7 \begin{array}{lll}7 & 20 & 60\end{array}$

Columbia. Very early and of finest quality, . . . . . $\quad 7 \quad 20 \quad 50$

Burpee's Improved Blood Turnip. A fine strain, . . $\quad 6 \quad 6$ I $5 \quad 40$

The Lentz. Popular for forcing, . . . . . . . . . . 6 I5 65

Bastian's Half Long, or Philadelphia Perfection, . . $\quad 6 \quad$ I 540

Long Smooth Blood=Red. For table and cattle, . . . $\quad 5 \quad$ io 25

Early Yellow Turnip. Rich yellow color, . . . . . $\quad 5 \quad$ Io 30

Swiss Chard, or Silver Beet (Large=Ribbed Silver), .

In regular size packets, each of the above, 5 cents per packet.

\section{SUGAR BEETS AND MANGEL WURZELS.}

Improved Wanzleben. The best for sugar, .

Red Top Sugar. Clean, handsome roots,. . .

Lane's Improved Imperial. For cattle feeding,

Per Oz. $\quad 1 / 4$ th. Pertb.

Danish Improved. Productive and nutritious,

Champion Yellow, or Orange Globe Mangel,

Red Globe Mangel. Smaller in size ; red skin,

Golden Giant Intermediate, or Leviathan, .

Golden Tankard, Yellow=Fleshed Mangel,

5 IO

22

20

22

\section{BORECOLE, or KALE.}

Dwarf German, or German Greens,

\begin{tabular}{|c|c|c|}
\hline $\begin{array}{ll}\text { Per Oz. } \\
\text { \$o } 07\end{array}$ & $\begin{array}{l}1 / 4 \mathrm{mb} . \\
\$ 0 \quad 20\end{array}$ & $\begin{array}{l}\text { Per Ib. } \\
\text { \$O } 55\end{array}$ \\
\hline 6 & I 5 & \\
\hline 7 & 25 & \\
\hline Io & 25 & \\
\hline
\end{tabular}

Tall Green Curled Scotch. Two and a half feet high,

Dwarf Purple Kale. Deep purple, curled leaves, . . .

Curled Mosbach. Crimped, light-green leaves,

In regular size packets, each of the above, 5 cents per packet.

\section{BROCCOLI.}

Purple Cape. Large brownish-purple head, . . \$0 10 \$0 20.\$060 \$2 $\$ 25$

\section{BRUSSELS SPROUTS.}

Perfection. Grows about two feet high, . . . $\quad \begin{array}{lllll}5 & \text { Io } & 25 & 85\end{array}$

Paris Market. A fine, new half-dwarf variety, $\quad 5 \quad$ io 30 I 00 


\section{CABBAGE,-Extra Early Varieties.}

Early Jersey Wakefield. The best first-early, . . . . \$O I5 Charleston, or Large Wakefield. About ten days later, Earliest Etampes. Extra early, oblong heads, . . . . Extra Early Express. The earliest of all cabbages, . . Early Winningstadt. Very hard, pointed heads, . . Early Dwarf York. Very early; small, heart-shaped, . . Large Early York. About ten days later ; larger in size,

\begin{tabular}{|c|c|c|}
\hline Per Oz. & $1 / 4 \mathrm{tb}$. & Per $\mathbb{\# b}$. \\
\hline$\$ \circ \quad$ I 5 & $\$ 040$ & $\$ I \quad 50$ \\
\hline I 5 & 40 & I 50 \\
\hline 7 & 25 & 75 \\
\hline IO & $3^{\circ}$ & I 00 \\
\hline IO & $3^{\circ}$ & I 00 \\
\hline 7 & 25 & \\
\hline 7 & 25 & \\
\hline
\end{tabular}

In regular size packets, each of the above, $\mathbf{5}$ cents per packet.

\section{CABBAGE,-Second=Early or Summer.}

Burpee's Allhead Early. Earliest flat-head. . . . . . Early Cannon Ball. Hard, round heads, of small size, Early Dwarf Flat Dutch. A first-class second-early, . Henderson's Early Summer. A favorite. Pkt. Io cts., Fottler's Drumhead, or Short=Stem Brunswick, . . All Seasons. Fine large head, quite early, . . . . . . Henderson's Succession. A good second-early cabbage, Vandergaw, or Midsummer. Similar to All Seasons, .

\begin{tabular}{|c|c|c|}
\hline Per Oz. & $1 / 4 \mathrm{fb}$. & Per $\mathrm{fb}$. \\
\hline \$O I 5 & $\$ 040$ & $\$ I \quad 50$ \\
\hline IO & 30 & I $O$ \\
\hline IO & 35 & I 2 \\
\hline IO & 35 & I 2 \\
\hline IO & 35 & I 2 \\
\hline IO & 35 & \\
\hline IO & 30 & I OC \\
\hline IO & 35 & I \\
\hline
\end{tabular}

Except where priced, each variety. is $\mathbf{5}$ cents per packet.

\section{CABBAGE,-for Autumn and Winter.}

Acme Flat Dutch. A quick-grozing strain of Flat Dutch, Autumn King, or World Beater, . . . . . . . . Lupton. Uniformly fine, solid heads, . . . . . . . . Danish Ball=Head. Hard; medium size. Pkt. Io cts., Danish Ball=Head. Grown in Denmark. Pkt. Io cts., Burpee's Surehead. Always sure to head. Pkt. Io cts., Burpee's Short=Stem Drumhead, . . . . . . . . . Burpee's Safe Crop. Fine for late winter, . . . . . . Stone $=$ Mason Marblehead. Of weak constitution, . . Filderkraut, or Pomeranian Pointed Heading, . . . Premium Flat Dutch. Well known and popular,... Burpee's Superior Large Late Flat Dutch, . . . . . Large Late Drumhead. For autumn and winter cabbage, Louisville Drumhead. Of dark bluish-green color, . . Marblehead Mammoth. Coarse heads; poor quality, .

\begin{tabular}{|c|c|c|c|}
\hline Per Oz. & $1 / 4 \mathrm{fb}$. & & $=r$ to. \\
\hline$\$ 0 \quad 10$ & $\$ 030$ & $\$ I$ & $O C$ \\
\hline I 5 & 40 & I & 5 \\
\hline I 5 & 40 & I & 5 \\
\hline 20 & 60 & 2 & \\
\hline 25 & 75 & 2 & 5 \\
\hline 5 & 40 & I & \\
\hline 20 & 60 & 2 & \\
\hline I 5 & 40 & I & \\
\hline IO & 30 & I & \\
\hline IO & 30 & I & \\
\hline 7 & 25 & & 9 \\
\hline IO & 30 & I & 0 \\
\hline 10 & 30 & I & \\
\hline IO & 35 & I & \\
\hline IO & 30 & & \\
\hline
\end{tabular}

\section{CABBAGE,-Savoy and Red Varieties. Per Oz. ${ }^{\mathrm{I} / \mathrm{tb}} \mathrm{tb} \quad$ Per th.}

Belleville Savoy. New; very solid small heads. Pkt. I o cts., \$o 25

Perfection Drumhead Savoy. Finest quality; hard, . Io

Early Blood=Red Erfurt. Small and hard, . . . . : Io

Large Red Drumhead, or Improved Red Dutch, . . I 5

Red Poland. Nere; hard heads, darkest red. Pkt. Io cts., 25

Mammoth Rock Red. Very large heads, . . . . . . I I

Hard=Heading Red. "Solid as a rock." Pkt. Io cts., 20

$\begin{array}{rrrr}\$ 0 & 30 & \$ I & 00 \\ 35 & \text { I } & 25 \\ 35 & \text { I } & 25 \\ & & \\ 40 & \text { I } & 50 \\ 60 & 2 & 00\end{array}$

Except where priced otherwise, each variety is $\mathbf{5}$ cents per packet.

Seeds by Weight. Please remember that the prices quoted herein are net for prices "per packet" are subject to a discount of thirty=three and one=third per cent. See second page cover. 


\section{GARDEN CARROTS.}

\begin{tabular}{|c|c|c|c|c|}
\hline $\begin{array}{l}\text { Oz. } \\
\text { o7 }\end{array}$ & $\begin{array}{l}1 / 4 \\
\$ 0\end{array}$ & 20 & & \\
\hline 6 & & I 5 & & 45 \\
\hline 6 & & I 5 & & 45 \\
\hline 6 & & I 5 & & 35 \\
\hline 6 & & I 5 & & 45 \\
\hline 6 & & I 5 & & 40 \\
\hline 7 & & 20 & & $5^{\circ}$ \\
\hline IO & & 35 & I & 25 \\
\hline 6 & & I 5 & & 40 \\
\hline 6 & & I 5 & & 35 \\
\hline 6 & & I 5 & & 45 \\
\hline
\end{tabular}

Golden Ball, or Earliest Short Horn for Forcing, .

Short Horn, or Early Scarlet Horn. Very popular, .

Oxheart, or Guerande. Smooth, handsome, and tender,

Half=Long Scarlet, Stump=rooted, . . . . . . . . .

Danvers Half=Long Orange. A great favorite, . .

Chantenay, or Model. One of the finest in quality,. .

New Meaux. A fine, coreless, long, stump-rooted, .

New Lonig Yellow, Stum p=rooted. Per pkt. Io cts., .

Saint Vallery, or New Intermediate. I 2 inches long,

Burpee's Improved Long Orange. A very fine strain,

Coreless Long Red. Grows I 2 to if 6 inches long,...

Each of the above, except where otherwise priced, 5 cents per packet.

\section{CARROTS FOR CATTLE FEEDING.}

Long Red Altringham. Long, bright-red roots, . .

Large White Vosges. Suitable for shallow soils,. . .

Improved Short White. The best and most productive, Large White and Large Yellow Belgian. Each,. .

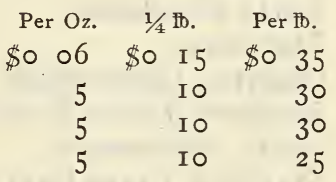

Per Pkt.

$\$ 0025 \quad \$ 2 \quad 75$

25200

20200

I0 90

$5 \quad 55$

I0 65

IO 60

550

Per Oz.

$\$ 020$

25

I 5

I 5

I 5

I 5
$1 / 4 \mathrm{Hb}$.

$\$ 950$

750

$700 \$ 2600$

$\begin{array}{llll}3 & 25 & \text { I } 2 & 00\end{array}$

I $60 \quad 6 \quad 25$

200

I 60

750

$\begin{array}{ll}7 & 50 \\ 6 & 00\end{array}$

I 50

550

1/4 tb. Per BD.

$\$ 070 \quad \$ 225$

75250

40 I 50

40 I 50

40 I 50

50 I 50

30 I 00

30 I 00

30 I 00

30 I 00

35 I 25

35 I 25

$25 \quad 80$

Celeriac, or Turnip=Rooted Celery. True Apple=Shaped,

Each of the above, 5 cents per packet.

CHICORY.

Large=Rooted, or Coffee,
Per Pkt. Per Oz. $\$ 007$
$1 / 4$ th.

Per Ib. $\$ 060$

\section{COLLARDS.}

Fine Georgia. Used in the South for "greens," 5

7

25

75

CORN SALAD, or VETTICOST.

Large Round=Leaved, Large=Seeded 


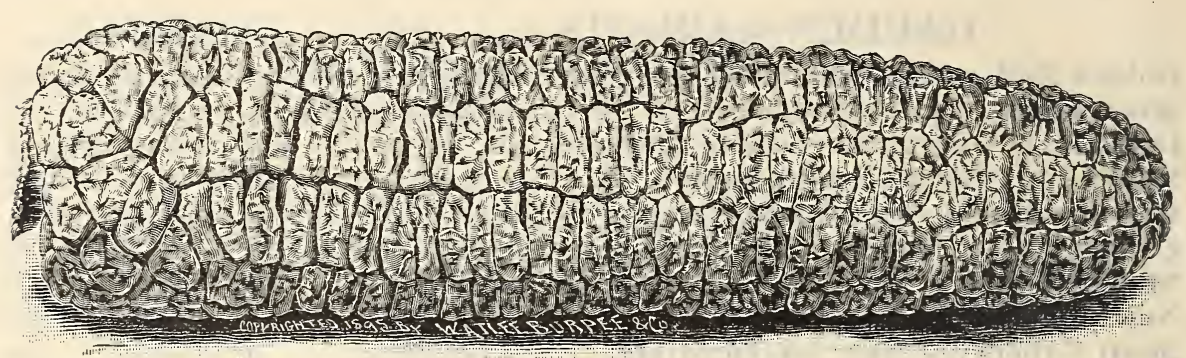

An Ear of EARLY FORDHOOK SWEET CORN. Engraved from a Photograph, reduced in size.

\section{SWEET CORN.}

First of All,

Early Fordhook, . . . . . . .

The Cory,

Country Gentleman,

Shaker's Large Early,

Early Minnesota, . . . . . . .

Stabler's Extra Early, . . . . . .

Stowell's Evergreen(2 bush.@\$2.00),

All Other Varieties, as named below,

\begin{tabular}{|c|c|c|c|c|}
\hline & \multirow{2}{*}{$\begin{array}{l}2 \text { Quarts. } \\
\$ 030\end{array}$} & \multirow{2}{*}{$\begin{array}{l}4 \text { Quarts. } \\
\$ \circ \quad 50\end{array}$} & Peck. & Bushel. \\
\hline \$O 20 & & & $\$ 085$ & $\$ 300$ \\
\hline 25 & 35 & 55 & 90 & 350 \\
\hline I 5 & 25 & 35 & 60 & 200 \\
\hline I 5 & 25 & 35 & 60 & 200 \\
\hline I 5 & 25 & 35 & $6_{5}$ & $2 \quad 25$ \\
\hline I 5 & 25 & 35 & 60 & 200 \\
\hline I 5 & 25 & 45 & 75 & 250 \\
\hline I 5 & 25 & 40 & 60 & 210 \\
\hline I 5 & 25 & 35 & 60 & 210 \\
\hline
\end{tabular}

Extra Early Adams,-Marblehead Early,_Crosby's Early Twelve= Rowed,-Perry's Hybrid,-Potter's Excelsior, or Squantum,-Amber Cream,-Ne Plus Uitra, or Shoe Peg,-Stabler's Pedigree,-Mammoth Late, and Egyptian.

Each variety of Sweet Corn, 10 cents per packet.

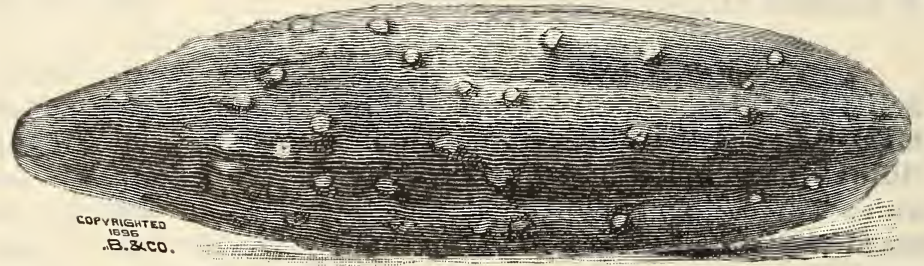

FORDHOOK PICKLING CUCUMBER. Engraved from a Pholograph.

\section{CUCUMBERS.}

Early Russian. Earliest of all ; small dark-green, . Improved Early White Spine, or Arlington, . . . Peerless White Spine. Straight ; full at both ends, . Hill's Forcing White Spine. A fine strain,. . . . . New Extra Early White Spine. Extremely early, . . Fordhook White Spine. The best strain, . . . . . . Fordhook Pickling. Best for pickling. Per pkt., Io cts., Evergreen, or Extra Long White Spine, . . . . Early Frame, or Early Short Green, . . . . . . . Early Green Cluster. A short, prickly, seedy variety, Extra Early Green Prolific, or Boston Pickling, . . Cool and Crisp. Very prolific; extra early, . . . . . Thorburn's Everbearing. Vines bear continuously, . Burpee's White Wonder. The best white Cucumber, New Giant White. Long and handsome, . . . . . .

\begin{tabular}{|c|c|c|c|}
\hline Per Oz. & $1 / 4$ & tb. & Per th. \\
\hline 3० ○6 & $\$ 0$ & I 5 & $\$ 040$ \\
\hline 6 & & I 5 & 35 \\
\hline 6 & & I 5 & 40 \\
\hline & 71 & I 5 & 45 \\
\hline 7 & f & 20 & 5 \\
\hline 7 & & 20 & 50 \\
\hline IO & & 25 & 9 \\
\hline 7 & & 20 & 5 \\
\hline 6 & & 15 & 3 \\
\hline 6 & & I 5 & 3 \\
\hline 6 & & I 5 & 4 \\
\hline 6 & & I 5 & 45 \\
\hline 7 & & 20 & 5 \\
\hline 7 & & 20 & \\
\hline 20 & & 101 & \\
\hline
\end{tabular}

Except where priced, each of the above is $\mathbf{5}$ cents per packet. 


\section{CUCUMBERS,-Continued.}

Per Oz. $\quad 1 / 4 \mathrm{tb}$. Per th.

The “Emerald." Per pkt., Io cts.

Burpee's Giant Pera. Superb long green,

Paris Pickling. Fine for pickling,

Japanese Climbing. Twelve inches long,

Nichol's Medium Green. Full at both ends,

Livingston's Evergreen. Better than preceding, . .

Improved Chicago Pickle. The true Westerfield strain,

Extra Long Green Prickly. I 2 to I 4 inches long, . .

London Long Green. A very fine strain, . . . . . .

Burpee's White Pearl. Small, smooth, white fruits,

Serpent, or Snake. A vegetable curiosity, . . . . .

West India Gherkin. Exclusively for pickling, . .

\$o 10

IO

IO

7

6

\section{CRESS.}

Fine Curled, or Pepper Grass,

Water Cress. Grows in shallow water,

\begin{tabular}{|c|c|c|c|c|}
\hline $\begin{array}{ll}\text { er pkt. } \\
0 & 05\end{array}$ & $\begin{array}{l}\text { Per Oz. } \\
\$ 0 \text { o }\end{array}$ & & $\begin{array}{l}\text { th. } \\
\text { I } 5\end{array}$ & \\
\hline & 25 & & 90 & \\
\hline
\end{tabular}

IO

35

I $\circ \circ$

375

\section{EGG PLANT.}

New York Improved Large Purple. The best, Early Long Purple. Oblong; hardier and earlier, Extra Early Dwarf Round Purple. Very small, The Pearl. Magnificent large fruits; white skin,

10

5

IO

IO

\section{ENDIVE.}

Green Curled. The hardiest variety

White Curled. The most attractive in appearance,

Broad=Leaved Batavian. Broad, thick leaves,

\section{GOURDS.}

Sugar Trough. Useful for household purposes, Io

Dipper. Makes excellent dippers,... .. . Io

Dish Cloth, or Luffa. Sponge-like porous lining, Io Japanese Nest Egg. White ; size of hens' eggs,

\section{HORSE RADISH.}

Small Roots. Per I00, $\$ 0.60 .0^{\circ}$

\section{KOHL RABI.}

Green or White. Good for stock feeding,

Early White Vienna. Best for the table,

Early Purple Vienna. Differs only in color,

\section{LEEK.}

Broad London Flag. Large, with broad leaves, Monstrous Carentan, or Scotch Champion, . 


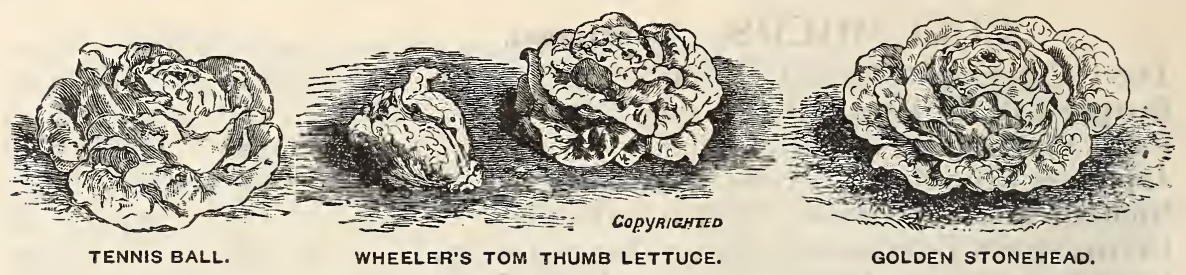

\section{LETTUCE,-for Forcing.}

White=Seeded Tennis Ball, or Boston Market,

Black=Seeded Tennis Ball. Extremely hardy, . . . .

Wheeler's Tom Thumb. Hard, little heads,

Per Oz. $\quad 1 / 4 \mathrm{tb} . \quad$ Per $\mathrm{tb}$.

Hittinger's Belmont Forcing, or New Hot=Bed, .

Big Boston. Larger; for forcing later, ...... . .

Black=Seeded Butter. Similar to Tennis Ball, but larger,

Yellow=Seeded Butter. Dense yellow heads; crisp, .

Philadel phia Speckled Dutch Butter. Fine for forcing,

Stonehead Golden Yellow. Handsome, solid heads, .

Grand Rapids. A famous cutting lettuce for forcing, .

\begin{tabular}{|c|c|c|c|}
\hline$\$ 007$ & $\$ 0$ & 25 & $\$ 0$ \\
\hline 7 & & 25 & -0 \\
\hline IO & & 35 & I \\
\hline 7 & & 25 & \\
\hline 7 & & 25 & \\
\hline 7 & & 25 & \\
\hline 7 & & 25 & \\
\hline 7 & & 25 & \\
\hline IO & & 30 & I \\
\hline 7 & & 25 & \\
\hline
\end{tabular}

Each Lettuce, named above, 5 cents per packet.

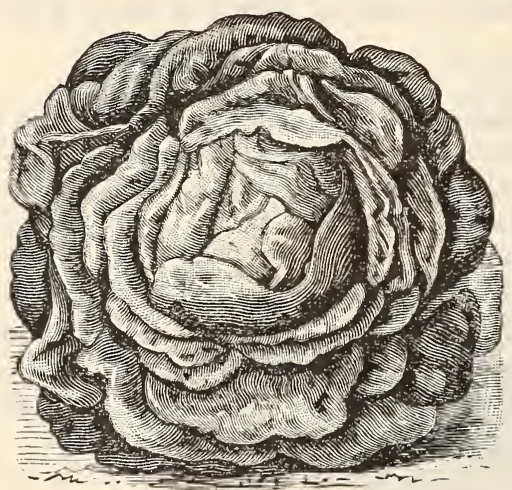

BURPEE'S HARD-HEAD LETTUCE.

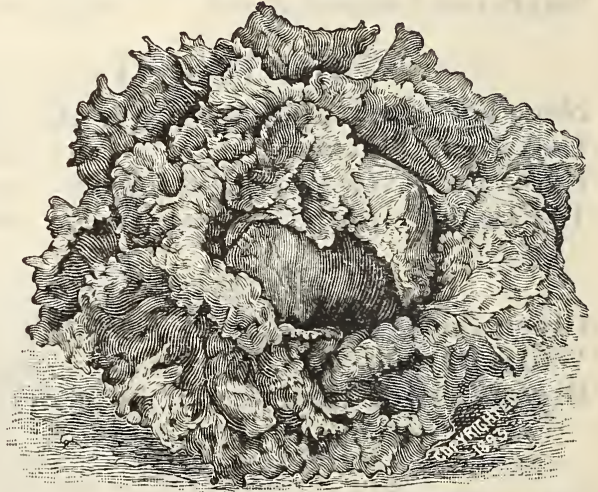

NEW ICEBERG LETTUCE.

\section{LETTUCE,--for the Open Ground.}

Early Curled Silesia. A leading early sort for cutting, Early Curled Simpson. Loose heads; early and tender, Black=Seeded Simpson. Large and lighter in color, . The Morse. A white-seeded Simpson, . . . . . . . Mignonette. Solid, dainty little heads, . . . . . . . Burpee's Silver Ball. Solid, silvery-white heads, . . Burpee's Hard Head. Very solid, . . . . . . . . Thick=Head Yellow. Grand Buttery heads, . . . . . Hanson. Very solid, crisp, large heads, . . . . . . . Onond aga. A cutting lettuce; outer leaves shaded brown, Blonde Blockhead, Hard heads of golden-yellow, . . Gold Nugget. Fine, golden-yellow heads ; of rich flavor, San Francisco Market, or The Deacon, . . . . . . California Cream Butter, or Royal, . . . . . . . . New Iceberg. Very hard, crisp heads, . . . . . . . Boston Curled. Of poor quality, but great beauty, . .

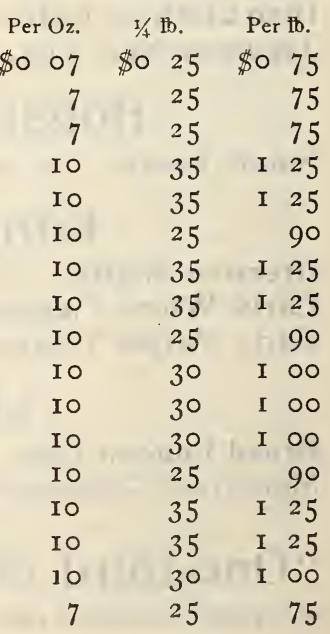




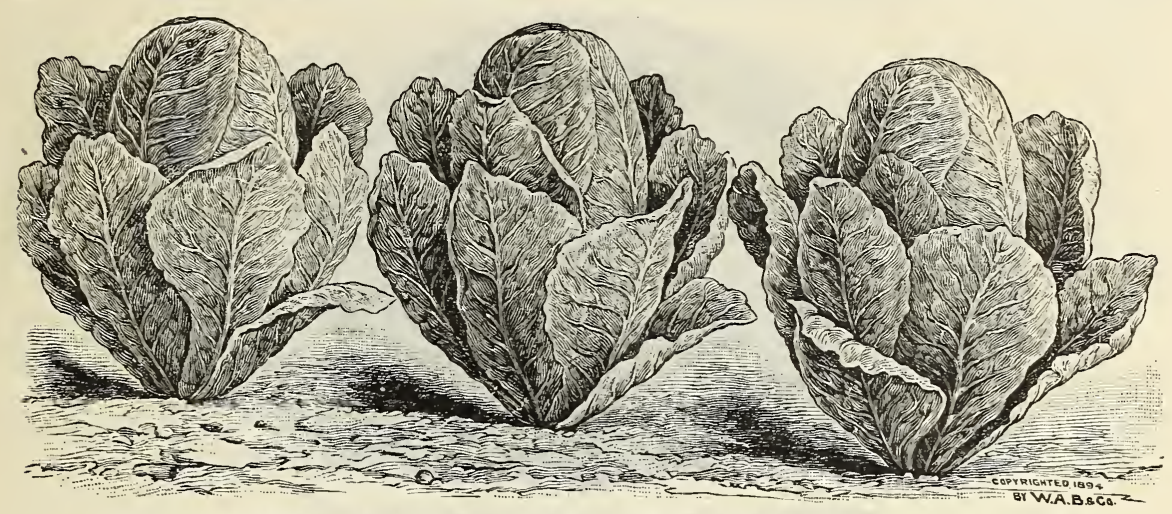

DWARF WHITE HEART COS LETTUCE. As Grown at Fordhook Farm. Engraved from a Photograph.

\section{LETTUCE,-Continued.}

Green Fringed. Most ornamental in growth, .

Early Prize=Head. Loose heads, tinged with brown, .

Denver Market. Large, solid heads ; fine quality, .

New York. Large, solid heads; very dark green in color, Philadelphia Early White Cabbage. Fine, handsome, Paris Self=Folding White Cos. Upright and crisp, . . Giant White Cos. Of large, upright growth ; fine, . .

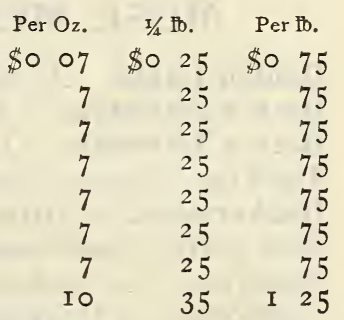

Each of the above, price 5 cents per packet.

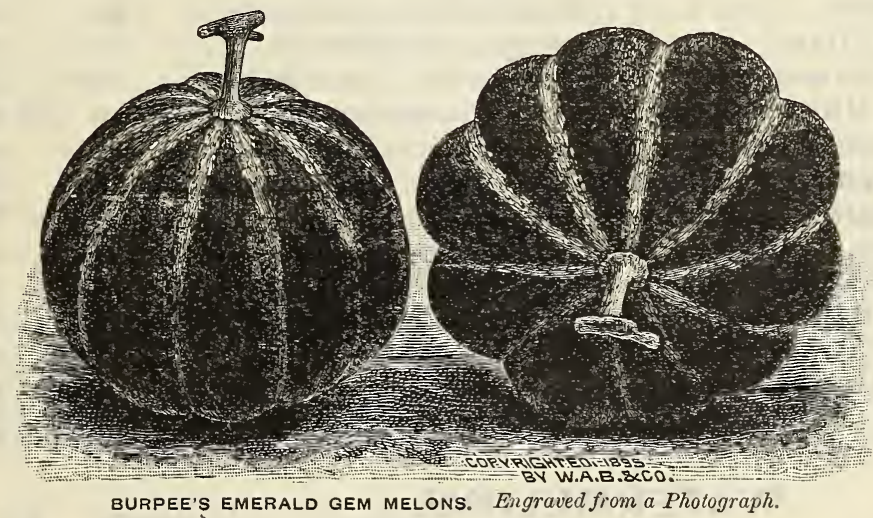

\section{MUSK MELONS, or Cantaloupes.}

Early Jenny Lind. Small, early; fine, light-green flesh, Burpee's Netted Gem. Small, round, extra early ; green, Burpee's Champion Market. Larger and later,. . . Emerald Gem (Burpee's). Green skin; salmon flesh, Cannon Ball. Round, netted; rich, light-green flesh, . Cosmopolitan. Netted, but not ribbed; green flesh, . Long Island Beauty. Large, early, green-fleshed, . Montreal Green Nutmeg. Of immense size ; green flesh, Burpee's Bayview. Oblong melons of large size, . . . Burpee's Melrose. Salmon flesh; delicious, . . . . . Grand Rapids. A large melon, salmon flesh; very early,
Per Oz. $\quad 1 / 4 \mathrm{tb}$. Per tb. $\$ 006$ \$० I5 \$० 45 6 I $5 \quad 50$ $\begin{array}{lll}7 & 25 & 75\end{array}$

$6 \quad$ I $5 \quad 45$

$720 \quad 60$

6 I $5 \quad 45$

6 I $5 \quad 50$

6 I $5 \quad 45$

6 I $5 \quad 40$

$\begin{array}{lll}7 & 25 & 75\end{array}$

6 I $5 \quad 45$

Each of the above Melons, price 5 cents per packet. 


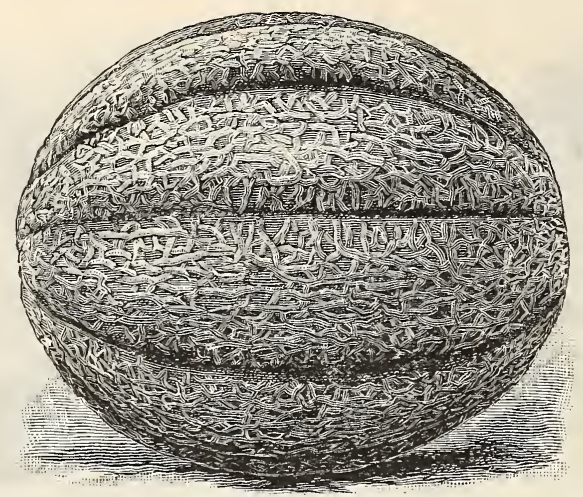

BURPEE'S GOLDEN EAGLE MELON. From a Photograph.

\section{MUSK MELONS, or Cantaloupes,-Continued.}

Golden Eagle. Novelty, I898. Per pkt. Io cts., . . . $\$ 035$

Beck's Columbus. Netted, buff skin; green flesh, . . 6

Beck's Triumph. Oval; medium size; sweet red flesh, Tip=Top. Smooth skin; sweet, juicy, salmon flesh, . . . Hackensack, or Turk's=Cap. Large; green flesh, . . . New Early Hackensack. Ten days earlier, . . . . . Superior. Round, densely netted; sweet light-green flesh, Perfection, or Princess. Nutmeg; salmon flesh, . . . New Superb. A handsome late melon; sweet, green flesh, Jersey Belle. Extra Early; beautiful deep-green flesh, . Reedland Giant. A long cantaloupe; green-fleshed, . . Prolific Nutmeg. Round, heavily netted; green flesh, . Osage, or Miller's Cream. Flesh of rich salmon; sweet, Green=fleshed Osage. Pea-green; of delicious flavor, . White Japan. Smooth, light skin; thick, musky flavor, The Banquet. Densely netted; salmon flesh . . . . . Delmonico. Oval shape, netted; orange-pink flesh,. . Perfected Delmonico. More uniform in shape, . . . . Acme, or Baltimore. Oblong, pointed ; light-green flesh, Banana. Grows 18 to 24 inches long; a curiosity, . . Boston Mango. Useless as fruit, but best for "Mangoes,"

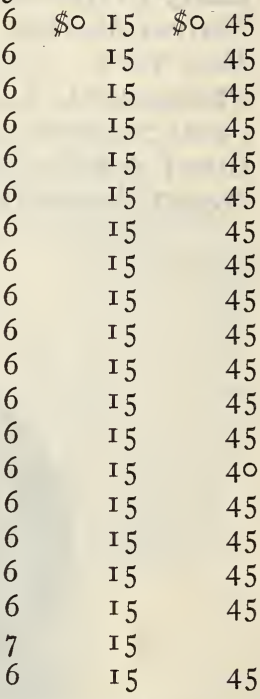

Except the Golden Eagle, each of the above, $\mathbf{5}$ cents per packet.

\section{WATERMELONS.}

Phinney's Early. An extra early; of medium size, . . Vick's Early. Extra early; oblong; skin varies in color, Fordhook Early. Earliest large melon. Per pkt. io cts., Dark Icing, or Ice Rind. Of round form ; sugary flavor, Cole's Early. Extra early, but thin skinned, . . . . . Sweet Heart. Light-green skin; rich, red flesh, . . . Burpee's Cubain Queen. The old favorite, . • . . McIver Sugar. Oblong, striped skin; fine for market, . Jordan's Gray Monarch, or Long White Icing, . . . Burpee's Mammoth Ironclad. Large, oblong, . . . . Delaware. Oblong, striped; sweet, red flesh,... . . The Dixie. A famous oblong, Southern melon, . . . .

\begin{tabular}{|c|c|c|}
\hline Per Oz. & $1 / 4 \mathrm{mb}$ & Per Ib. \\
\hline$\$ \circ \circ 6$ & $\$ 0 \quad$ I 5 & $\$ \circ \quad 35$ \\
\hline 6 & I 5 & 35 \\
\hline IO & 30 & I 00 \\
\hline 6 & I 5 & 35 \\
\hline 7 & 20 & \\
\hline 6 & I 5 & 45 \\
\hline 6 & I 5 & 3 \\
\hline 6 & I 5 & 4 \\
\hline 6 & I 5 & \\
\hline 6 & I 5 & \\
\hline 6 & I 5 & 7 \\
\hline 6 & I 5 & 35 \\
\hline
\end{tabular}

Except the FordHook EARLy, each of the above, 5 cents per packet. 


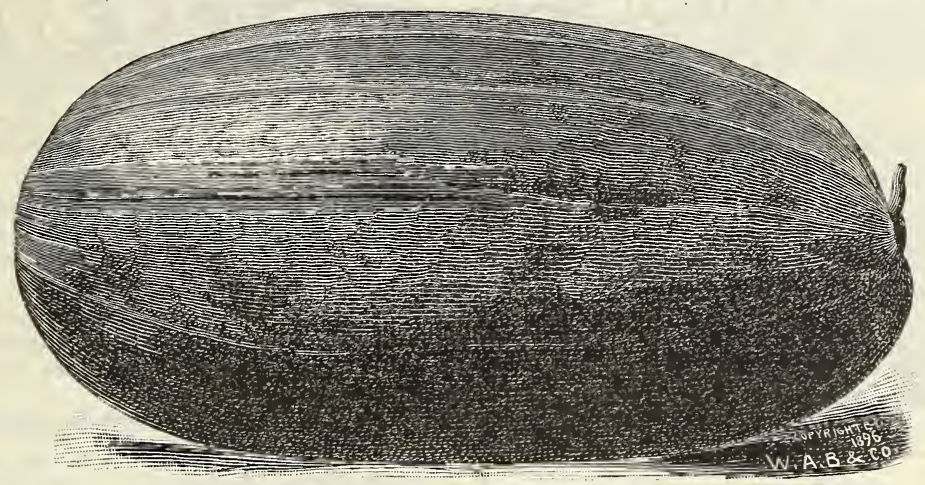

KLECKLEY SWEetS WATERMELON. From a Photograph.

\section{WATERMELONS,-Continued.}

Kleckley Sweets. Sweetest of all. Per pkt. Io cts., . Burpee's Hungarian Honey. Small; rich, red flesh, Burpee's White Gem. Small; white skin, . . . . . Duke Jones. A famous new Southern melon, . . . . Florida Favorite. An oblong melon, of fine flavor, . . Girardeau's New Favorite. An improved strain, . . Pride of Georgia. Round in shape ; skin striped, . . . Seminole. Similar to Jordan's Gray Monarch, . . . . Ice Cream, or Peerless. True zuhite-seeded; oblong, . Per Oz. $\quad 1 / 4 \mathrm{mb} . \quad$ Per $\mathrm{Db}$. \$O IO \$O $35 \quad \$$ I 25 $7 \quad 20 \quad 60$ $7 \quad 20 \quad 60$ 6 I $5 \quad 45$

Red=Seeded Vaucluse. Of elongated egg-shape ; superb, Kolb's Gem. The great market melon; carries well, . The Boss. Oblong melon; of small size, good flavor, . Kentucky Wonder. A popular market melon in the West, Striped Gypsy, or Georgia Rattlesnake, . . . . . . The Jones. A great favorite in the South; rich flavor, . Ruby=Gold. Flesh yellow and red; not recommended, . Colorado Preserving. The best for citron preserves, . Each of the above, except the KleCKLey Sweets, 5 cents per packet.

\section{MUSTARD.}

Black or Brown. Grown for salad, ....... \$o ०5 \$0 10 \$0 25 White. Better for salad, . . . . . . . . . 55 Io 25 New Chinese, or Southern Giant Curled, . . . . . $\quad 6 \quad 6 \quad$ I5 35

\section{NASTURTIUM.}

Tall Mixed. Seed-Pods useful for pickling, . . . . . 725

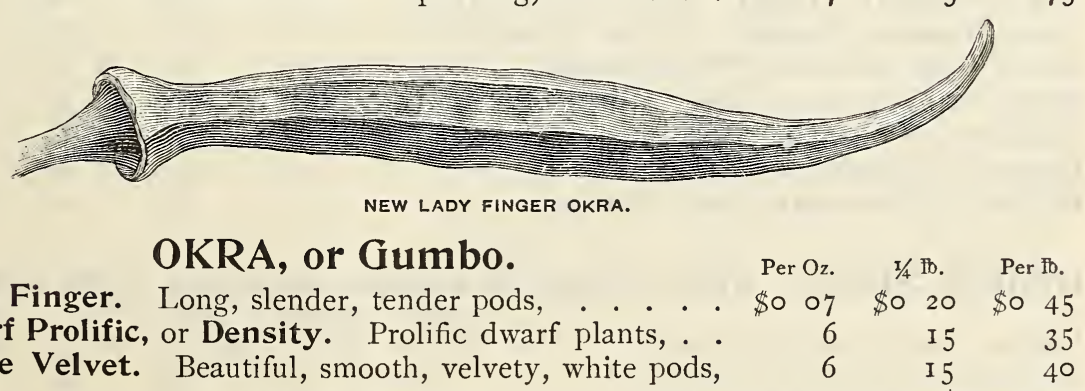

Lady Finger. Long, slender, tender pods, . \$० ०7 \$० $20 \quad \$ 0 \quad 45$

Dwarf Prolific, or Density. Prolific dwarf plants,. . $6 \begin{array}{lll}6 & \text { I } 5\end{array}$

White Velvet. Beautiful, smooth, velvety, white pods, 6 I $5 \quad 40$ All varieties of Mustard, Nasturtium, and Okra are 5 cents per packet. 

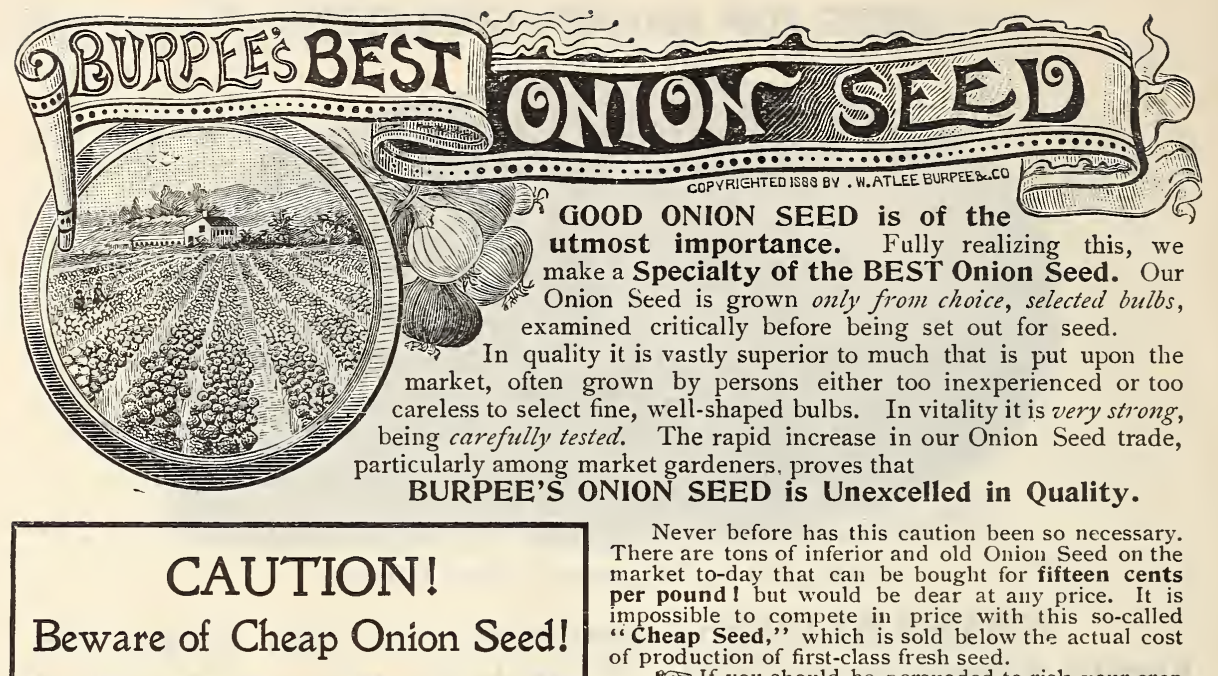

Never before has this caution been so necessary. There are tons of inferior and old Onion Seed on the market to-day that can be bought for fifteen cents per pound ! but would be dear at any price. It is impossible to compete in price with this so-called "Cheap Seed," which is sold below the actual cost of production of first-class fresh seed.

If you should be persuaded to risk your crop by planting this "Cheap Onion Seed," we ask, in your interest as well as our own, that you plant also an ounce or a pound of BURPEE'S ONION SEED alongside, in the same field, and Note the Difference in Crop !

\section{ONIONS-American Varieties.}

Yellow Danvers. The well-known favorite, . Best Yellow Globe Dan vers. Unsurpassed strain, Southport Large Yellow Globe. True globe, Yellow Strasburg, or Dutch. Flat ; dark yellow, American=Grown Yellow Prize=Taker, Extra Early Red. Extra early and long keeping, Large Red Wethersfield. The favorite red, . Large Red Globe. Larger, but later, White Silverskin, or White Portugal. Flat, Philadelphia Silverskin. For growing white sets, Large White Globe. True Southport strain, Extra Early White Pearl,or Bloomsdale Pearl,

\begin{tabular}{|c|c|c|c|c|c|c|}
\hline Per Oz. & $1 / 4$ & & Per 1 & & & $\begin{array}{l}\text { bs. } \\
\text { zore, } \\
\text { mb. }\end{array}$ \\
\hline$\$ 007$ & $\$ 0$ & I 5 & $\$ 0$ & 50 & $\$ 0$ & 45 \\
\hline 7 & & 20 & & 60 & & 55 \\
\hline 7 & & 20 & & 60 & & 55 \\
\hline 7 & & 20 & & 60 & & 55 \\
\hline IO & & 30 & I & ০০ & & 95 \\
\hline 7 & & 20 & & 60 & & 55 \\
\hline 7 & & 20 & & 60 & & 55 \\
\hline 7 & & 20 & & 60 & & 55 \\
\hline IO & & 35 & I & 40 & I & 35 \\
\hline IO & & 35 & I & 40 & I & 35 \\
\hline IO & & 35 & I & 40 & I & 35 \\
\hline 10 & & 35 & I & 40 & I & 35 \\
\hline
\end{tabular}

All Onions are 5 cents per packet.

NOTE.-Purchasers are entitled to the five=pound rate on orders of five pounds of one kind, either American or Italian Onions. Purchasers are entitled also to the five=pound rate when the total order amounts to five pounds, provided there is not less than one pound to a variety.

\section{ONIONS-Italian Varieties.}

Earliest White Queen,

Neapolitan Maggiajola, or Italian May Onion, Giant White Italian Tripoli. Large flat onions, Red Mammoth Tripoli. Similar, with red skin, Giant Rocca of Naples. Globe; brown-red, . Silver Ball, or Giant White Rocca, . . . . Burpee's Mammoth Silver King, Mammoth Pompeii. Reddish skin. ..... Burpee's Mammoth White Victoria, . Burpee's Mammoth Red Victoria, .

\begin{tabular}{|c|c|c|c|c|c|}
\hline Per Oz. & $\mathrm{x} / 4 \mathrm{tD}$. & $\mathrm{Pe}$ & $\mathrm{tb}$. & & tore, \\
\hline to IO & $\$ \circ 35$ & $\$ I$ & 30 & $\$ I$ & 20 \\
\hline 10 & 35 & I & IO & I & $O C$ \\
\hline 7 & 25 & & 85 & & 8 \\
\hline 7 & 25 & & 85 & & 8 \\
\hline 7 & 25 & & 80 & & 7 \\
\hline IO & 35 & I & 35 & I & $3 c$ \\
\hline IO & 35 & I & 35 & I & 3 \\
\hline IO & 30 & I & IO & I & 00 \\
\hline IO & 35 & I & 40 & I & 35 \\
\hline IO & 30 & I & IO & I & \\
\hline
\end{tabular}

ONION SETS. Prices subject to changes, according to the market.

Yellow, best Philadelphia sets, White, best Philadelphia sets, White Multiplier Onion Sets,

\begin{tabular}{|c|c|c|c|c|}
\hline Quart. & 2 Quarts. & ${ }_{4}$ Quarts. & Peck. & Bushel. \\
\hline$\$ 020$ & $\$ 030$ & $\$ 0 \quad 50$ & $\$ 075$ & $\$ 275$ \\
\hline 20 & 35 & 55 & 90 & 00 \\
\hline 25 & 40 & 75 & 25 & 40 \\
\hline
\end{tabular}




\section{Long-Keeping AUSTRALIAN BROWN ONION.}

The Most Valuable Variety Introduced in a Generation.

All efforts to introduce American Onions in Australia have failed, because Australian seedsmen claimed that they had an Onion better than any of ours. We fouud that the Onion grown almost exclusively in Australia, is the one which we offer now under the name of AUSTRALIAN BROWN. From the best stock that could be obtained in Australia splendid bulbs were grown and fine crops of seed harvested in 1896 and 1897 , which can be obtained only direct from us. Onions are grown extensively in Australia, and as practically every grower confines himself to this one variety, there is naturally great rivalry anong seedsmen to have the best seed of so important a crop. Just as in America improved strains of th olḋ Philadelphia Extra Early Pea have been given many different names, so in Australia this Onion has a like multiplicity of names. The two leadiug names are MARKET MoDEL and BRown GLOBE. $\Lambda$ s the onions, however, are not perfectly globular (being much earlier than any true globe-shaped onion), we call it simply AUSTRALIAN BROWN ONION.

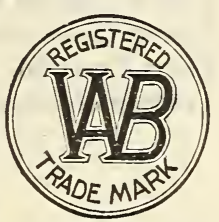

THE AUSTRALIAN BROWN ONION is of medium size, wonderfully hard and solid, and most attractive for market, both as to form and appearance. The illustration was engraved from a photograph, while the painting on last year's cover was made from nature, but failed adequately to show the handsome appearance of these beautiful onions. They are extremely early in ripening, and never make any stiff-necks or scallions. Every seed seems to produce a good-sized onion, and the bulb begins to form very quickly, when the plant is not orer three inches high. Planted with the Red Wethersfield, it proved to be nearly four weeks earlier and ripened off more uniformly. It has the reputation of keeping indefinitely, and we think from its firmness and hardness that it will keep in good condition longer than any other Onion known. The color of the skin is a clear amber-brown. So widely contrasted fiom any other Onion is this color that it will be noticed on market, and when once bought, purchasers will be most likely to return and call again for " those beautiful brown onions."

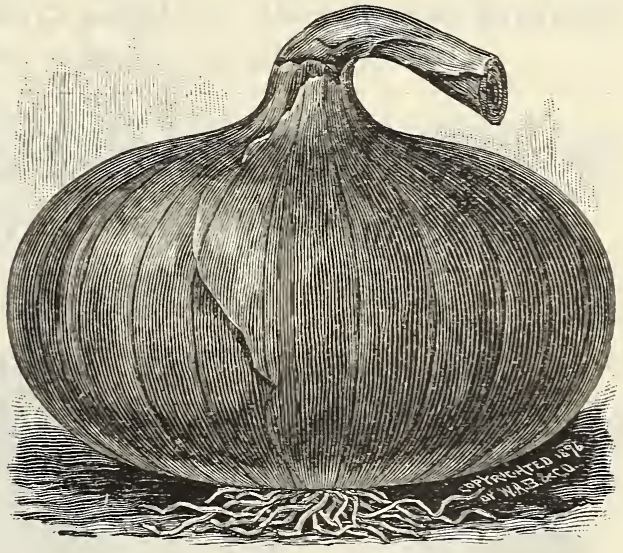

AUSTRALIAN BRCWN ONION. Per pkt. 10 cts.; oz. 15 cts.; $\frac{1}{4}$ tb 50 cts.; per $\mathrm{tb} \$ 1.80 ; 5$ Hbs. at $\$ 1.70$ per th. A Sample Letter. We hare received the strongest testimony from different sections as to the in packets and ounces. It has been so generally tested, howerer, that although we have space for but one sample report, we are sure of a large demand this season from the thousands who tried it last year, solely on our recommendation. Uulike other foreign varieties this is the best keeper of all onions, and beiug extra early it is a sure cropper even in the far north. We are confident that rou can make no mistake iu planting largely, either for home or distant markets, of THE AUSTRALIAN BROWN ONION.

Mr. Herman Blueher. Albuquerque, N. M., September 8, 1897, writes: "Yours of September 1st quoting onion seeds came duly to hand, price being satisfactory. Please send by mail four pounds of AUSTRALIAN BROWN ONION seed, and keep in reserve for me twelre pounds of the same AusTRALIAN BRowy OyIOY SEFD that I will want from you to be shipped with other seeds that I will order from rou next winter or spring. Please let me know if I can depend upon you keeping same for me, for I think it THE BEST ONION that I have ever seen or raised in my twenty years of gardening, and want to sow them exclusively for keeping."

\section{Early Onion,-}

\section{YELLOW CRACKER.}

We offer now an extra fine stock of the true " Early Cracker," which is undoubtedly the earliest of all yellow onions. A leading grower in Massachusetts says also : "It is the best of all yellow onions in quality, but needs to be harvested as soon as it dies down, and to be handled as carefully as an apple." It is flatter than any other onion,-hence the name Cracker. It has a very small top and is a sure cropper. It is an extra good keeper; in fact, keeps better and longer than any other variety known, excepting only The New Australian Brown. Per pkt. 5 cts.; oz. 10 cts. ; $\frac{1}{4}$ th 30 cts.; per tb $\$ 1.00$.

\section{Gigantic Onion,- "GIBRALTAR."}

Introduced by us in 1895 , we have nerer succeeded in getting sufficient seed of this fine yellow globe onion to offer in larger quantities than packets until the past season, and now we can sell it only in packets and ounces. Mr. T. GREINER, in a letter to the editor, published in Glearings is BeE Culture, of October 15, 1897, writes :

"In regard to that new onion which sour printer namied 'Garganus,' let me state that it is Burpee's Gibraltar, a most excellent variets for fancy trade, equal to the imported Spanish, nearly as large, as mild, and of a light-straw color; mus be sold promptly, as it does not seem to be a good keeper, especially in a wet season like this. I hope that next year we shall be able to procure seed at least by the ounce; for the past three years we could get it only by the packet, at rather high prices."

Per pkt. 10 cts.; per oz. 20 cts. 


\section{PARSLEY.}

Plain or Single. Plain leaves, excellent flavor, Fine Double Curled. Dwarf; crimped leaves, Extra Curled Dwarf, or Emerald. Beautiful, Extra Dark Moss Curled. Very dark green, . Fern=Leaved. Delicately cut leaves, . . . . Turnip=Rooted, or Hamburg. Grown for roots,

\begin{tabular}{|c|c|c|c|c|c|}
\hline Per Oz. & \multicolumn{2}{|c|}{$1 / 4 \mathrm{tb}$. } & Per $\#$. & $\begin{array}{l}5 \mathrm{fbs} \\
\text { mo } \\
\text { per }\end{array}$ & $\begin{array}{l}\text { s. or } \\
\text { ore, } \\
\text { r mb. }\end{array}$ \\
\hline$\$ 006$ & $\$ 0$ & I 5 & $\$ 035$ & $\$ 0$ & 30 \\
\hline 6 & & I 5 & 35 & & 30 \\
\hline 6 & & I 5 & 40 & & 35 \\
\hline 7 & & 20 & 55 & & 50 \\
\hline 6 & & I 5 & 40 & & 35 \\
\hline .6 & & I 5 & 40 & & 35 \\
\hline
\end{tabular}

5 IDs. or Per Oz. $\quad 1 / 4$ th. Per fb. \$० 06 \$० $15 \quad \$ \circ 35 \$ \$ \circ 30$ $6 \quad$ I $5 \quad 35 \quad 30$ $6 \quad$ I $5 \quad 35 \quad 30$

Early Short Round French. The earliest; small, Improved Guernsey, or Half Long. 'The best, Improved Long Smooth, or Hollow Crown, .

In regular size packets, each variety 5 cents per packet.

\section{New Extra Early Pea,-G RADUS. The Only First=Early Wrinkled Pea!}
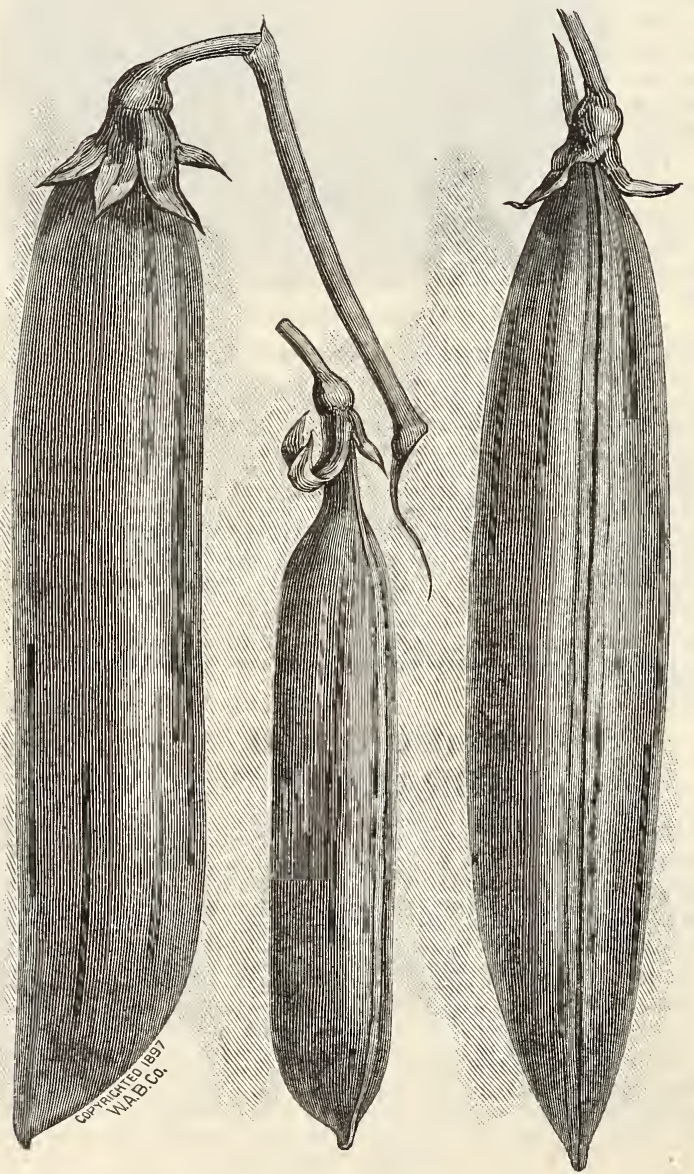

From three years' trials at ForDHook FARM, as well as from two years' extensive field culture, we can say truthfully that The GRADUS will yield an abundant supply of the most delicious, large, wrinkled peas much EARLIER than any other wrinkled variety, and only three or four days after the best stocks of the small round extra earlies.

It is the earliest large $=$ podded pea in cultivation, while the peas are of most superior quality, both in size and delicious flavor. They are quite equal to such well-known favorites as Telephone, Duke of Albany, or Burpee's Profusion.

The vine has heavy stems, with large, dark-green leaves, and grows three feet in height. It produces uniformly large pods, measuring four to four and one-half inches long, nearly round, and well filled with large, handsome peas. The peas remain edible-tender and sweetfor some time. The illustration herewith was engraved from a photograph of two pods of GRADUs, in contrast with one pod of Burpee's Best Extra Early (the best of the smallseeded, round, extra early peas) and shows a fair comparison,-all being exactly natural size.

Per pkt. 15 cts.; 2 pkts. for 25 cts.; pint 20 cts.; quart 35 ets.; 2 quarts 65 cts.; 4 quarts $\$ 1.10$; peck $\$ 2.00$; per bushel $\$ 7.50$.

GRADUS means a step, and this is, indeed, a long step in the right direction! A writer in England says: "It is the earliest of all peas,-earlier even than the small, round-seeded varieties, and has long, handsome, well-filled pods, each containing

The large pods are GRADUS PEAS in contrast with Burpee's Best Extra Early,-all natural size, from Photograph taken at FORDHOOK FARM. 


\section{PEAS,_Small, Round=Seeded Extra Earlies.}

"Burpee's Best" Extra Early.

Quart. 2 Quarts. 4 Quarts. Peck.

Bushel.

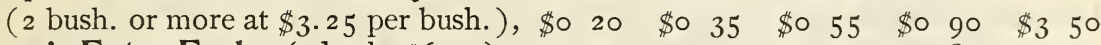

Burpee's Extra Early. (2 bush. \$6.00), $\quad \begin{array}{lllll}20 & 30 & 50 & 85 & 325\end{array}$

Dan O'Rourke, or First and Best, . $\quad \begin{array}{llllll}\text { I } 5 & 25 & 45 & 80 & 275\end{array}$

Alaska, or Laxton's Earliest of All, . $\quad \begin{array}{llllll}5 & 25 & 45 & 80 & 275\end{array}$

Tom Thumb,.......... . . $20 \quad 35 \quad 60$ I $10 \quad 400$

PEAS,_Extra Early Wrinkled.

New Extra Early Gradus. Pkt. I 5 cts. , 35

American Wonder, . . . . . . . . 20

Nott's Excelsior, . . . . . . . 20

William Hurst, . . . . . . . . 20

McLean's Little Gem, . . . . . . . 20

Extra Early Premium Gem, . . . 20

$\begin{array}{lllllll}65 & \text { I } & \text { I O } & 2 & \circ 0 & 7 & 50 \\ 35 & & 65 & \text { I } & \circ 0 & 3 & 75 \\ 35 & & 65 & \text { I } & \circ 0 & 3 & 75 \\ 35 & & 65 & \text { I } & \circ 0 & 3 & 75 \\ 35 & & 50 & & 90 & 3 & 25 \\ 35 & & 50 & & 90 & 3 & 25\end{array}$

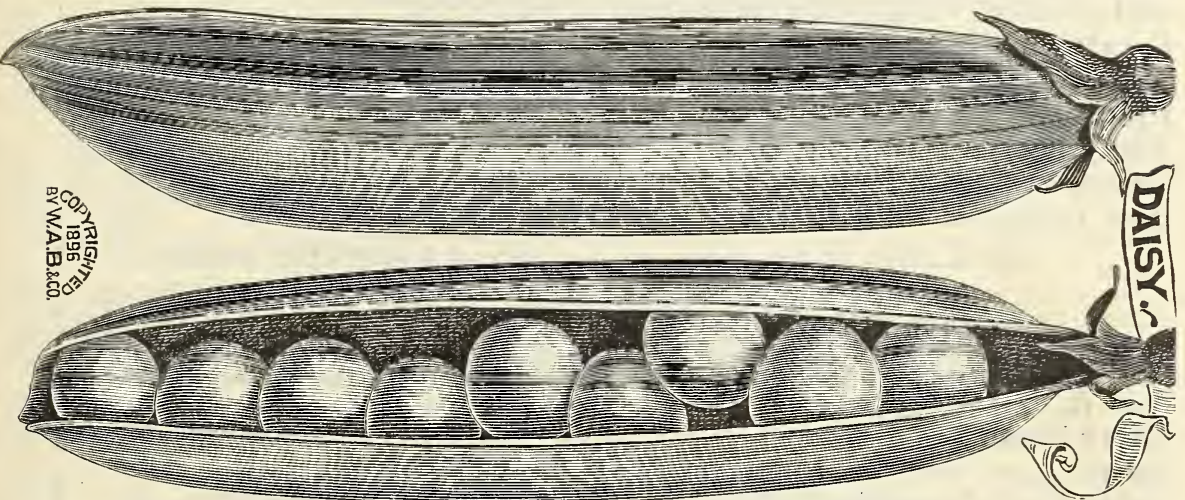

PEAS, - Main $=$ Crop Varieties .

Champion of England,

Yorkshire Hero,

Pride of the Market

Improved Pride of the Market, . . .

Improved Stratagem,

Laxton's Evolution,

Burpee's Quantity

Burpee's Quality, . . . . . . . .

Carter's Daisy,

Burpee's Profusion,

Everbearing and Abundance, each, .

Eckford's Echo and Renown, each,

Horsford's Market Garden,

Telephone (Long Island Wrinkled),

Duke of Albany,

Heroine,

Shropshire Hero,

Perfect. Per pkt. I 5 cts.

Dwarf Blue Imperial,

Royal Dwarf White Marrowfat,

Black=Eyed Marrowfat,

Dwarf Sugar and Tall Sugar, each,
Quart.

$\$ \circ \quad$ I 5

I 5

20

30

20

25

25

25

30

25

20

20

20

20

20

20

20

35

35

I 5

I 5

I 5

20
2 Quarts. 4 Quarts.

$\begin{array}{llllllll}\$ \circ & 25 & \$ \circ & 45 & \$ 0 & 80 & \$ 2 & 75\end{array}$

25

35

50

35

40

45

45

50

45

35

35

35

35

40

35

35

65

65

25

25

25

35

Peck. Bushel.

$45 \quad 80 \quad 275$

65 I $20 \quad 450$

90 I 60600

65 I I $5 \quad 4 \quad 50$

70 I $20 \quad 450$

$80 \times 35 \quad 500$

80 I $35 \quad 500$

90 I $60 \quad 600$

80

50

60

50

65

70

65

65

I IO

I 10

40

40

40

65
I 35

$$
90
$$

I $0 \circ$

90

I 00

I I 5

I 00

I 00

200

200

65

65

65

I 20

450

All Peas (except Gradus, Perfect, and St. Duthus) are Io cts. per pkt., of two ounces. 


\section{PEPPERS.}

Improved Large Bell, or Bull=Nose. Large, mild, . Burpee's Ruby King. Largest, mild peppers. Pkt. Io cts., Sweet Mountain, or Mammoth. Similar to Bull-Nose, Spanish Monstrous. Very large, thick-fleshed; red, . Long Red Cayenne. True Cayenne; hot and pungent, True Red Chili. Small, bright-red peppers; very hot, . Dwarf Early Red Squash. Thick-fleshed; early,. . Golden Dawn. Golden-yellow peppers; mild and sweet, Celestial. Small fruits; creamy; scarlet when ripe,. . Kaleidoscope. Of changing colors,-cream to scarlet, . The Mikado. Handsome, new variety. Per pkt. Io cts., Burpee's Golden King. Mild yellow. Pkt. Io cts., . Burpee's Golden Upright. Sweet yellow. Pkt. Io cts., Black Nubian. Long, mild, black peppers. Pkt. Io cts., Red Cluster. Small, thin, hot peppers. Pkt. Io cts., . Coral Gem Bouquet. Brilliant red; small, hot. Pkt. I octs., Tobasco. Extremely hot and fiery. Per pkt. io cts., . Procopp's Giant. Long, scarlet peppers. Pkt. Io cts., Fancy ScarletWrinkled. Turk's-cap shaped. Pkt. Io cts., Fancy Orange Wrinkled. Deep orange. Pkt. Io cts., New Fancy Wrinkled, Mixed. Per pkt. Io cts., . . .

\section{Per Oz.}

$\$ 020$

20

20

20

20

20

20

20

20

20

20

20

20

20

35

20

20

20

20
Per th. $\$ 060 \$ 200$ 60200 60200 60200 60200 60200 60200 60200 60200 60200 60200 60200 60200 $70 \quad 2 \quad 50$ I 25 75 75 75 75 Except where priced, each variety is $\mathbf{5}$ cents per packet.

\section{SEED POTATOES.}

In case of changes in the market, prices will be quoted by letter.

Early Beauty of Hebron,

Early Rose (True Stock), .

Extra Early Vermont, .

Early Ohio, .

Burpee's Superior

Carman No. I,

Rural New Yorker No. 2, .

Burpee's Empire State, .

White Star, .

White Elephant, or Late Beauty of Hebron,. . . .

Livingston's Banner,

World's Fair Premium,

\section{PUMPKINS.}

Small Sugar. Small orange-colored; sweet, . . . . Golden Marrow. Larger in size ; good keeper, . . . Cushaw, or Crookneck. Cream-colored, slightly striped, Large Cheese. Shape flat, like a cheese, . . . . . . Large Common Field. The common yellow pumpkin, . Calhoun. Creamy skin; fine salmon-yellow flesh,. . . Jonathan. Large crookneck, bottle-shaped, . . . . . Tennessee Sweet Potato, . . . . . . . . . . . . Japanese. Green-striped skin; rich orange flesh, . . . Banana Pumpkin. Also called Custard Squash, . . Burpee's Golden Oblong. Rich golden color ; fine flavor, Burpee's Quaker Pie. Cream color; excellent quality, Original Genuine Mammoth. Largest of all, . . . .

\begin{tabular}{|c|c|c|}
\hline Per Peck. & Per Bush. & Per bbl. \\
\hline$\$ 060$ & $\$ 160$ & $\$ 350$ \\
\hline 60 & I 60 & 350 \\
\hline 60 & I 60 & 35 \\
\hline 60 & I 60 & 35 \\
\hline 60 & I 60 & 35 \\
\hline 60 & I 60 & 35 \\
\hline 60 & I 60 & 35 \\
\hline 60 & I 60 & 35 \\
\hline 60 & I 60 & 35 \\
\hline 60 & I 60 & 35 \\
\hline 60 & I 60 & 35 \\
\hline 60 & I 60 & 3 \\
\hline
\end{tabular}

Per Oz. $\quad 1 / 4 \mathrm{tb} . \quad$ Per $\mathrm{mb}$.

\$० 06 \$० I 5 \$० 45

$7 \quad 20 \quad 60$

$7 \quad 20 \quad 50$

$6 \quad$ I $5 \quad 40$

5 IO 25

$6 \quad$ I $5 \quad 45$

$6 \quad$ I $5 \quad 45$

$7 \quad 20 \quad 50$

$7 \quad 20 \quad 60$

$7 \quad 20 \quad 60$

$\begin{array}{lll}7 & 25 & 75\end{array}$

$7 \quad 25 \quad 75$

IO 35 I 25

All of the above are 5 cents per packet. 


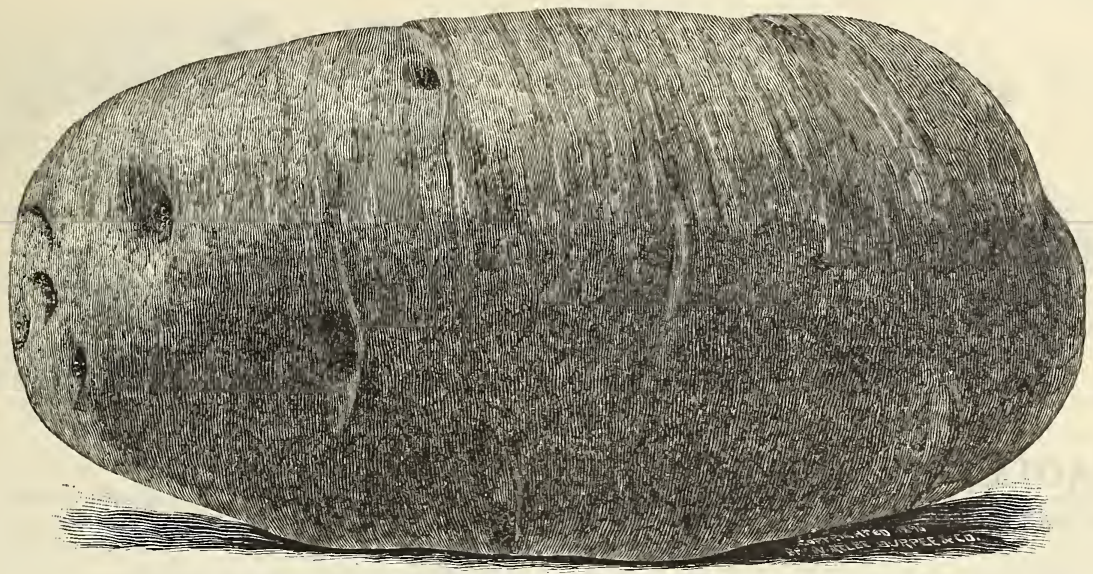

THE NEW EARLY THOROUGHBRED POTATO. Engraved from a Photograph.

\section{New Potato,-The Early THOROUGHBRED.}

The tubers are oblong in shape, smooth, and handsome ; of a light blush or pinkish color. In quality for the table, either baked or boiled, it is "simply perfection." The vine is a vigorous grower, sets its tubers compactly, and will mature AN IMMENSE CROP with very few smallsized Potatoes. It matures with the Early Rose.

Per peck 70 cts.; $\frac{1}{2}$ bushel $\$ 1.00$; per bushel of $60 \mathrm{tbs}$., $\$ 1.70$; per barrel of $165 \mathrm{lbs}$., $\$ 4.00$.

BURPEE'S EXTRA EARLY is from ten days to two weeks earlier while fully one week earlier than the Early Ohio and nearly twice as productive.

For description and illustration see page 73 of BURPEE'S FARM ANNUAL FOR 1898 Per peck 70 cts.; $\frac{1}{2}$ bushel $\$ 1.20$; per bushel of 60 tbs., $\$ 2.25$; per barrel of 165 tbs., $\$ 5.00$.

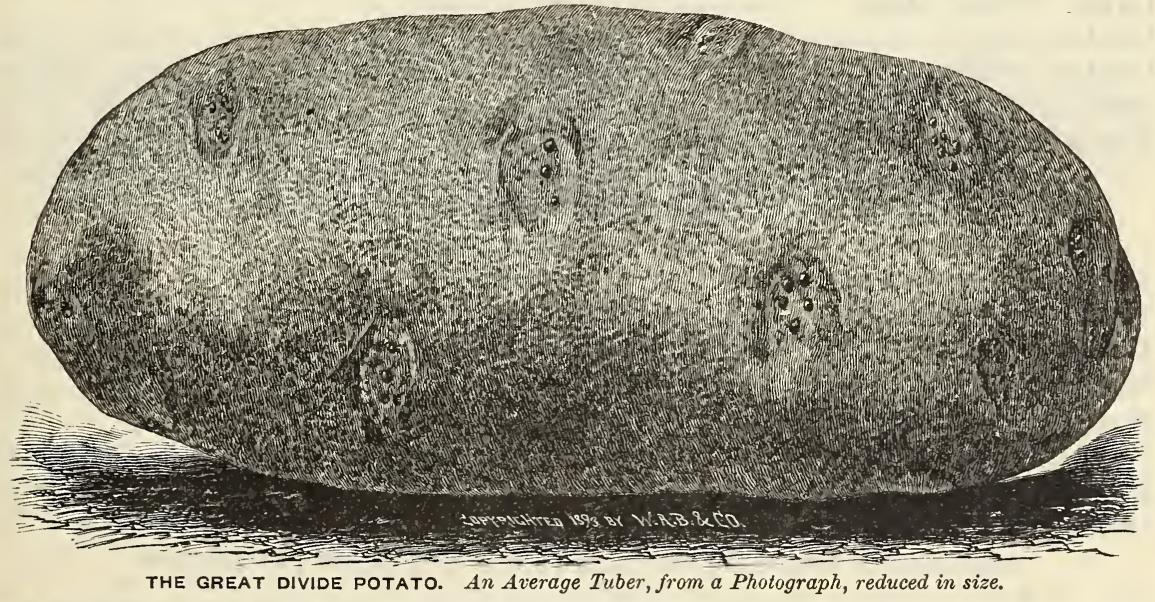

GREAT DIVIDE is the most robust=growing, heaviest=yielding, long. est=keeping, and best=shipping main=crop Potato. The vines are vigorous, stout, and erect; foliage plentiful, with dark-green leaves, withstanding drought, extreme heat, and attacks of insects better than any other variety ; perfectly free from disease, such as scab or blight. The tubers are of oblong, round form; eyes plentiful and on the surface, giving a handsome appearance, with almost no waste in paring. Skin very white, firm, and tough. Grows compactly in the hill, and, while the tubers are well under the ground, they are borne near the surface of the soil.

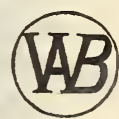
Size large to very large, with scarcely a small one. In season it is from medium to late. Its table qualities are unrivaled. The flesh is clear white, and when baked or boiled breaks open like a snowball,-white and floury. It cooks finely and very quickly, with a delicious nutty flavor.

Per peck 60 cts.; $\frac{1}{2}$ bushel $\$ 1.00$; per bushel of $60 \mathrm{tbs}$., $\$ 1.70$; per barrel of $165 \mathrm{tbs}$., $\$ 4.00$. 


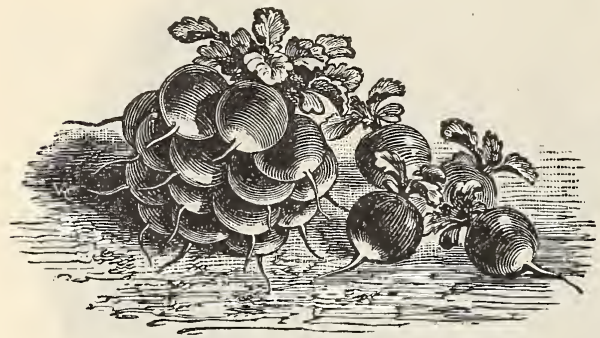

RUBY-PEARL RADISH.

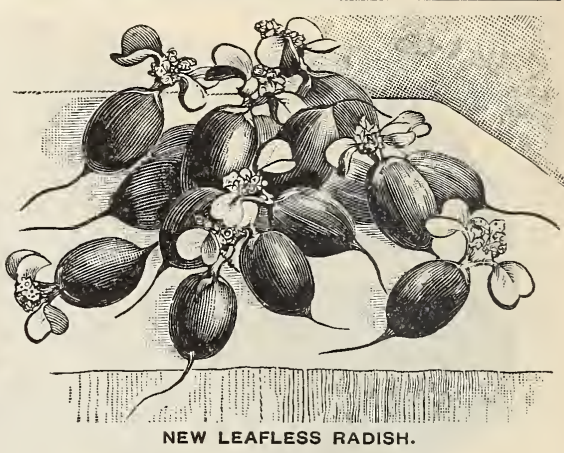

RADISH SEED. Our Radish Seed is all the best French=grown,-such as we have handled for twenty-two years. We could get seed much cheaper in England, and even in France, BUT, - the Best is none too good for our trade with the critical Market Gardeners. There are no better Seeds than BURPEE'S !

We supply 5 lbs. or more at $\mathbf{5}$ cts. per $\mathbf{l b}$. less than prices quoted below.

\section{RADISH,-Turnip=Shaped Varieties.}

Extra Early Scarlet Turnip. Small, round red, .

Early Round Dark Red. Very handsome; fine quality, Burpee's Earliest, or Improved Scarlet Button, . .

New Leafless. A remarkable novelty. Per pkt. io cts., Dark Red Ball. Deep scarlet turnip forcing radish, . . White=Tipped Scarlet Ball. Bright red, tipped white, Scarlet Turnip, White Tip. Also called Rosy Gem, . Ruby Pearl. Bright-red, tipped white. Per pkt. Io cts., Philadelphia White Box. Early, turnip-shaped, . . Large White Globe. Fine for spring and summer, . . Golden Globe. A favorite summer radish, . . . . . . Golden Dresden. White flesh; golden skin. Pkt. Io cts., Early White Turnip. Both skin and flesh white ; crisp., Early Turnip Varieties, Mixed. Above and others, .

\section{RADISH,-Olive=Shaped Varieties.}

\begin{tabular}{|c|c|c|c|c|}
\hline Per Oz. & $1 / 4$ & & & \\
\hline$\$ 0 \circ 6$ & $\$ I$ & I 5 & $\$ 0$ & 35 \\
\hline 6 & & I 5 & & 40 \\
\hline 7 & & 20 & t. & 60 \\
\hline 20 & & 75 & & \\
\hline 7 & & 20 & & 60 \\
\hline 7 & & 20 & & 60 \\
\hline 6 & & I 5 & . & 45 \\
\hline IO & & 30 & I & 00 \\
\hline 6 & & I 5 & & 40 \\
\hline 6 & & I 5 & & 4 \\
\hline 6 & & I 5 & & 3 \\
\hline IO & & 30 & I & or \\
\hline 6 & & I 5 & & 3 \\
\hline 6 & & I 5 & & 3 \\
\hline
\end{tabular}

French Breakfast. Olive-shaped ; red, tipped white, Scarlet Olive=Shaped. Quite early; olive-shaped, . . Early Oval Dark Red. Brilliant color; very early, . .

Earliest Carmine, Red Rocket, or Scarlet Globe, . .

New Bright Breakfast. Dark red, tipped white, . 


\section{RADISH,-_Long Varieties.}

Per Oz.

$1 / 4$ tb Per $\mathrm{fb}$.

Long Scarlet Short Top. The well-known favorite, . . \$o o6 \$० I 5 \$० 35

Long White Vienna, or Lady Finger Radish, . . . $6 \begin{array}{lll}6 & \text { I } 5 & 40\end{array}$

Long Cardinal, or New Long Brightest Scarlet, . . $\quad 6 \quad$ I $5 \quad 45$

Cincinnati Market. Fine strain of Long Scarlet, . . $\quad 7 \quad 20 \quad 50$

Chartiers, or Shepherd. Crimson, tipped with white, $6 \begin{array}{lll}6 & \text { I } 5\end{array}$

White Strasburg. A fine summer radish, of large size, $\quad 6 \quad$ i $5 \quad 45$

Half=Long Deep Scarlet. The New Orleans favorite, . $6 \quad$ I $5 \quad 45$

Wood's Early Frame. Similar to the Long Scarlet, . $\quad 6 \quad$ I $5 \quad 35$

Giant White Stuttgart. An immense white radish, . $\quad 6 \quad$ I $5 \quad 35$

Summer Radishes, Mixed. For use in family gardens, $\quad 6 \quad$ I $5 \quad 35$

Each variety named above is $\mathbf{5}$ cents per packet.

\section{RADISH,-Winter Varieties.}

Chinese Rose, or Scarlet China. Excellent,

California Mammoth White Winter. Immense size,

Round Black Spanish. The favorite winter Rettig, . .

Long Black Spanish Winter. Black skin; white flesh,

Long White Spanish Winter. White skin and flesh,

Osaka. New mammoth half-long white. Per pkt.

Io cts., . . . . . . . . . . . . . .

\begin{tabular}{|c|c|c|}
\hline Per Oz. & $\mathrm{I} / 4 \mathrm{tb}$. & Per $\mathrm{fb}$. \\
\hline & $\$ 0 \quad$ I 5 & $\$ \circ 45$ \\
\hline 7 & 20 & 50 \\
\hline 6 & I 5 & 4 \\
\hline 6 & I 5 & 35 \\
\hline 6 & I 5 & 3 \\
\hline 20 & 70 & \\
\hline 7 & 20 & \\
\hline
\end{tabular}

White Chinese, or Celestial. Best of all, . . . . 720

60

Each of the above, except Osaka, is 5 cents per packet.

\section{RHUBARB, or Pie Plant.}

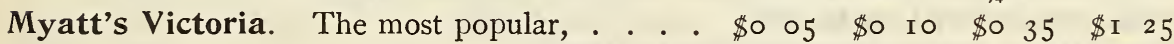

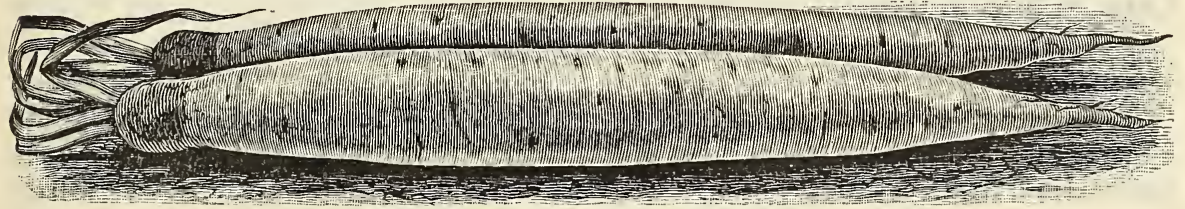

SANDWICH ISLAND MAMMOTH SALSIFY.

SALSIFY, or Vegetable Oyster.

Long White. The standard variety,

Sandwich Island Mammoth. The largest,

\section{SPINACH.}

New Victoria. Long standing; broad, dark leaves,

Thick=Leaved Round. Not equal to Victoria, Long=Standing, or Enkhuizen. For spring, . Long=Standing Prickly. A little later, . . . Prickly, or Winter. For fall sowing, . . . Norfolk Savoy=Leaved, or Bloomsdale Spin= ach,

New Zealand Spinach (Tetragonia Expansa),

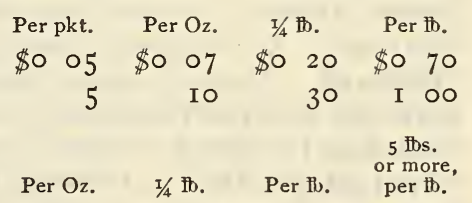

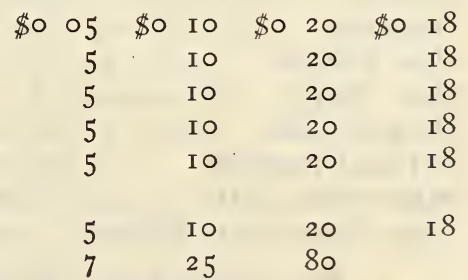

Each variety named above 5 cents per packet. 


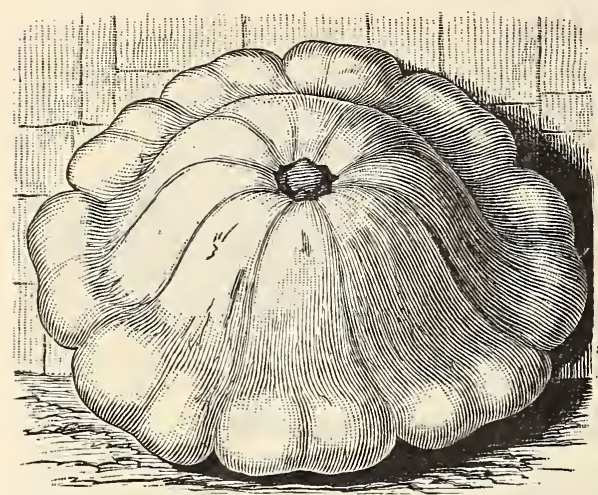

MAMMOTH WHITE BUSH SQUASH.

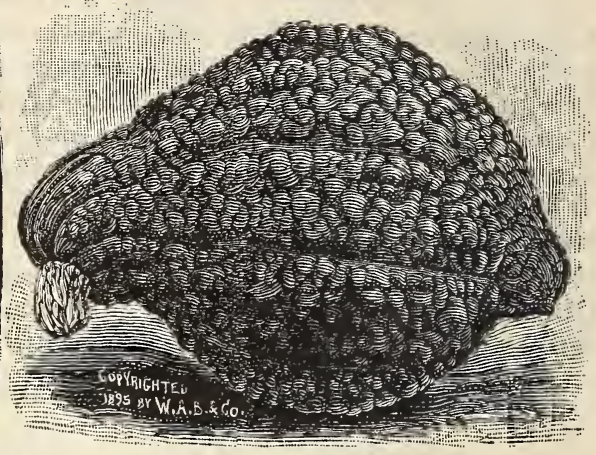

WARTED HUBBARD SQUASH.

\section{SQUASH,-Summer Varieties.}

Early White Bush, Scalloped. White Patty Pan

Early Yellow Bush, Scalloped. Deep-orange color, . New Mammoth White Bush, Scalloped, . . . . New Mammoth Yellow Bush, or Golden Custard, . . Golden Summer Crookneck. The small crook-necked, Strickler Summer. A running variety of Giant yellow, summer Crookneck, . . . . . . . . . Cocozelle Bush. Excellent to use young, fried, . . . Pineapple. Peculiar shape; white skin and flesh, . . New Giant Summer Crookneck. Eighteen inches long, White Summer Crookneck. Squashes are white, . . New Giant Yellow Summer Straightneck, . . . . . Long White Marrow. Per pkt. Io cents, . . . .

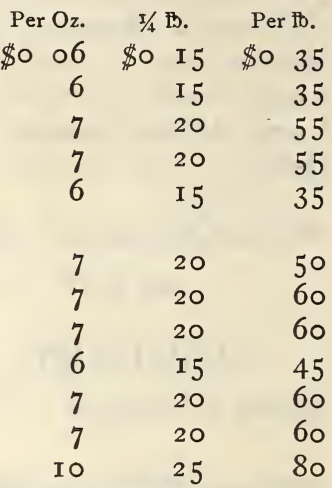
Except the last, each of the above is 5 cents per packet.

\section{SQUASH,_Fall and Winter Varieties.}

Fordhook. An all-the-year-round squash. Pkt. Io cts., Boston Marrow. A bright-orange squash for autumn use, Early Orange Marrow. Earlier and more productive, Brazil Sugar. The richest flavor in autumn, . . . . . Essex Hybrid. A good squash for fall and winter use, . Warren. An improved type of the Essex Hybrid, . . Hubbard. The well-known popular winter squash, . . Chicago Warted Hubbard. "An Ideal Hubbard," . New Red Hubbard. Bright, orange-red skin. Pkt. Io cts. Livingston's Pie, or Winter Luxury, . . . . . . . Faxon. Several colors; splendid flavor, . . . . . . Delicata. Small, oblong; fine flavor, . . . . . . . Pike's Peak. A most excellent winter squash, . . . . Der Wing. An ornamental, hard-shelled, little squash, Perfect Gem. Small, round, white squash for fall,, . . White Chestnut. "As dry as a boiled chestnut," . . Mammoth Chili. Large, round squashes, . . . . . . New Mammoth Whale. Immense. Per pkt. Io cts., Per Oz. $\quad \mathrm{I} / \mathrm{tb} . \quad$ Per $\mathrm{tb}$. $\$ 007 \quad \$ 020 \$ 060$ $\begin{array}{lll}6 & \text { I } & 35\end{array}$ 


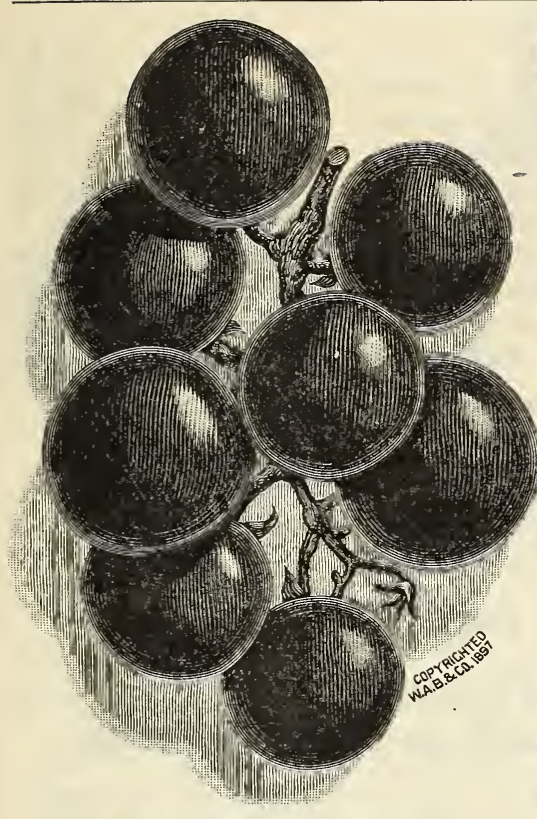

BURBANK PRESERVING TOMATO.

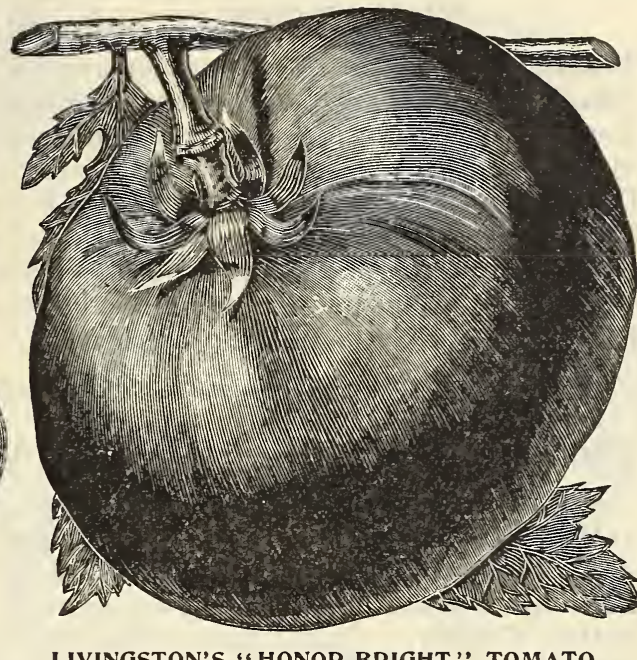

LIVINGSTON'S "HONOR BRIGHT" TOMATO.

"At first the fruit is light-green, then an attractive waxy white, then lemon, changing to rich bright red when ripe. The tomatoes are remarkable for their long-keeping qualities, and are specially recommended for shipping. Foliage greenish-yellow, but of vigorous growth."

Per pkt. Io cts.; oz. 20 cts.; $1 / 4$ th 60 cts.; per to $\$ 2.00$.

\section{Burpee's Seed of the Best TOMATOES.}

It is false economy to try to save on the first cost of Tomato Seed,-a little goes so far. And yet the country is almost "flooded" with cheap Tomato Seed, saved without any regard to selection, and sometimes even the refuse of canning establishments. Our Tomatoes are grown especially for seed, and largely by ourselves, in Bucks County, $\mathrm{Pa}$. This seed actually costs zus more than double the prices at which we are offered annually so-called "pure, cheap seed." "A word to the wise is sufficient."

Fordhook First. The earliest large tomato. Pkt. ro cts., Per Oz. $\quad$ I $/ 4 \mathrm{fb}$. Per $\mathrm{tb}$.

Fordhook Fancy. See $3 d$ page cover. Small pkt. 25 cts., New Imperial. Splendid fruits, color of Acme, . . . . Acme. The well-known standard bright-pink tomato, . . Beauty. Large, solid, smooth tomatoes; purplish-pink, Paragon. The well-known standard bright-red tomato, . Extra Early Advance. Very early; small, bright red, . Honor Bright. Description quoted above. Pkt. ro cts., Livingston's Perfection. Identical with Paragon, . Livingston's Favorite. Bright-red, smooth tomatoes, . Burpee's Climax. Smooth, solid, glossy pink, . . . . Essex Early Hybrid. Large, fine bright-pink fruits, . . Dwarf Champion. Dwarf, compact growth; pink fruit, Dwarf Aristocrat. Bushy growth; red fruits,.... Buckeye State. Large, solid, smooth; purple, ... Ignotum. Handsome, smooth, deep red, . . . . . . . Royal Red. Intense, bright red ; for canning, . . . . . Early Optimus. Handsome scarlet fruits ; quite early, . Volunteer. Bright red; moderately early; of fair size, . Stone. Large, solid; bright scarlet, . . . . . . . . . Chemin. Very prolific; distinctly apple-shaped, . . . . Trophy. Very large, solid, and generally smooth, . . . Thorburn's Long=Keeper. Bright red and early, . . . New Terra=Cotta. Skin of a pure terra-cotta color, .

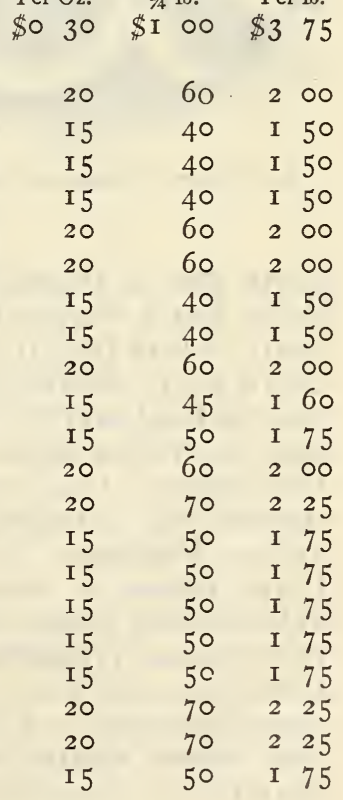

Except where otherwise priced, all Tomatoes are 5 cents per packet. 


\section{TOMATOES,-Continued.}

Trucker's Favorite. Best pink tomato. Pkt. Io cents, Matchless. Best of the standard red tomatoes. Pkt. Io cts., Turner Hybrid, or Mikado. Large red; potato-leaved, Mayflower. Bright red; splendid for forcing, . . . . Dwarf Golden Champion. Novelty. Per pkt. io cts. New Lemon=Blush. Flesh bright lemon-yellow, . . . Golden Queen. First-class, large, pure yellow tomato,. The Peach Tomato. Resembles the peach in form,. . Ponderosa, or No. 400. The largest of all. Pkt. Io cts.

Except where priced, each of the above Tomatoes, 5 cents per packet.

\begin{tabular}{|c|c|c|c|c|}
\hline Per Oz. & $3 / 4$ & th. & Per & \\
\hline$\$ 035$ & $\$ I$ & ০০ & $\$ 3$ & 75 \\
\hline 50 & I & 60 & 5 & \\
\hline 20 & & 70 & 2 & 25 \\
\hline 20 & & 70 & 2 & 2 \\
\hline$\cdot$ & & & & \\
\hline 20 & & 70 & 2 & 2 \\
\hline 20 & & 70 & 2 & 2 \\
\hline 20 & & 70 & 2 & 2 \\
\hline 30 & I & $\infty$ & 3 & 5 \\
\hline
\end{tabular}

\section{TOMATOES,-Small=Fruited Varieties.}

Red Pear=Shaped. The best for preserves, . . . . \$0 20

Yellow Plum=Shaped. Skin and flesh deep yellow, . .

Red Cherry. Little round fruits in clusters, . . . . .

Burbank Preserving. Small, sweetest red. Pkt. Io cts.

Yellow Cherry. Small, round, yellow fruits, . : . .

Strawberry, or Winter Cherry. Enclosed in husks, .

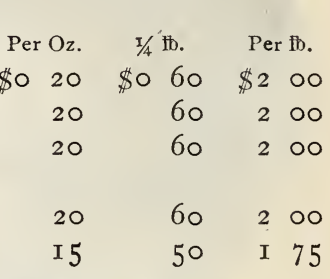

Except Burbank Preserving, each of the above 5 cents per packet.

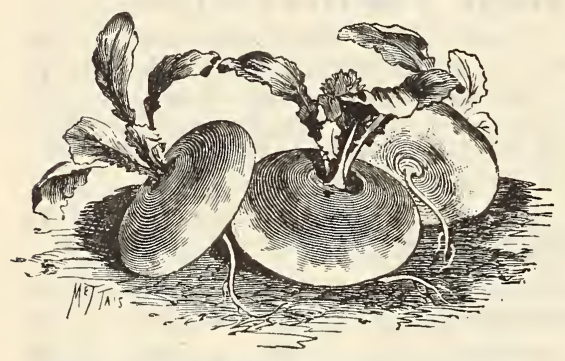

EXTRA EARLY PURPLE-TOP MILAN TURNIP.

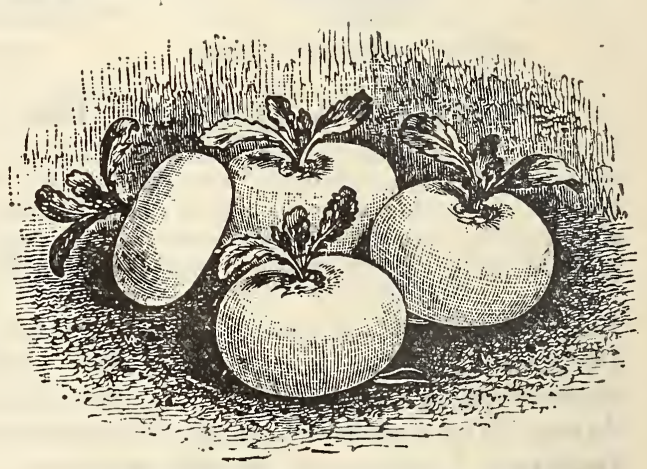

NEW EXTRA EARLY WHITE MILAN TURNIP.

\section{TURNIPS.}

Early Red, or Purple=Top Strap=Leaved,

Extra Early Purple='Top Milan, Strap=Leaved, . . .

Early White Flat Dutch Strap=Leaved, . . . . . .

Extra Early White Milan, .

Scarlet Kashmyr, or Cardinal Turnip, . . . . . .

Red Top White Globe. A fine table turnip, . . . . .

White Egg. Oval, with thin, white skin, . . . . . .

Golden Ball, or Orange Jelly. Tender, yellow flesh, .

Yellow Aberdeen. For both table and stock feeding, .

Large Yellow, or Amber Globe. Of large size, . . .

White Globe Strap=Leaved. Handsome white turnips,

Pomeranian White Globe. For stock feeding and table,

Half=Long Red Top. A new French variety, . . . .

Sweet German, or Long White French. For winter,

New White Winter. Oxheart-shaped. Per pkt. Io cts.,

Seven Top. For turnip greens,

\begin{tabular}{|c|c|c|}
\hline $\begin{array}{l}\text { Per Oz. } \\
\$ 006\end{array}$ & $\begin{array}{cc}\mathrm{I} / 4 \mathrm{fb} . \\
\$ 0 & \mathrm{I} 5\end{array}$ & $\begin{array}{l}\text { Per } \mathrm{tb} \text {. } \\
\$ 0 \quad 35\end{array}$ \\
\hline 7 & 20 & \\
\hline 6 & IO & \\
\hline 7 & 20 & \\
\hline 7 & 20 & \\
\hline 5 & IO & \\
\hline 6 & I 5 & \\
\hline 6 & I 5 & \\
\hline 5 & Io & 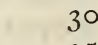 \\
\hline 6 & I 5 & \\
\hline 6 & IO & \\
\hline 5 & IO & 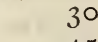 \\
\hline 6 & I 5 & \\
\hline 6 & I 5 & 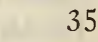 \\
\hline I 5 & & \\
\hline 6 & I 5 & \\
\hline
\end{tabular}

Each variety, except New WhIte Winter, 5 cents per packet. 


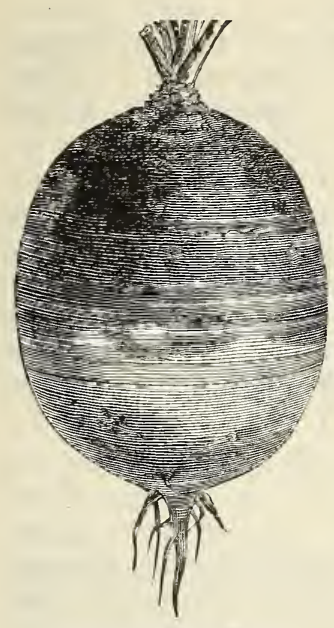

MONARCH RUTA BAGA.

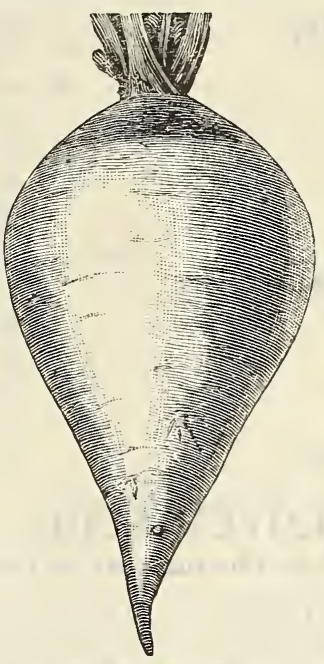

BURPEE'S BREADSTONE.

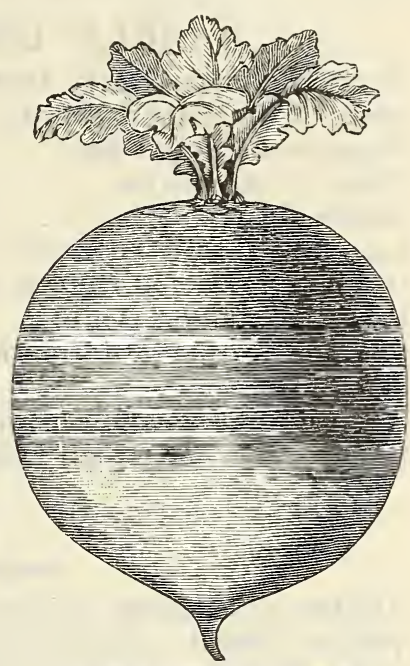

BURPEE'S IMPROVED PURPLE TOP.

\section{RUTA BAGAS, or SWEDES.}

Imperial Hardy. Purple top; yellow flesh, . . \$ం ० Burpee's Improved Purple-Top Yellow, . . . Monarch, or New Elephant. Oblong; yellow, Burpee's Breadstone. Of fine table quality, . Large White. Large, round; nutritious, sweet, Each variety, 5 cents per packet.

\section{TOBACCO.}

Connecticut Seed Leaf. Old and well known, Bradley Broad Leaf. One of the very best,. . Per Pkt. Per Oz. Cuban Seed Leaf. Very large leaves, . . . . Havana. One year from imported seed, . . . Lancaster County Broadleaf,

Bonanza. Very superior, . . . . . . . . Gold Finder. Very light-colored leaves, . . . General Grant. Matures even in Minnesota, . Six Other Varieties, each, .

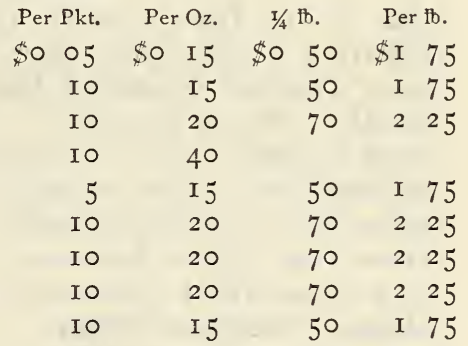

5 ftos. or more, \$० 22

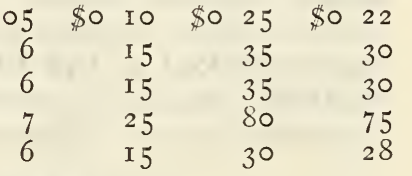

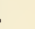




\section{FIELD CORN.}

Waterloo Extra Early Dent,

King of the Earlies Dent,

Mastodon Early Dent,

Pride of the North,

White Cap Dent,

Leaming Improved Dent,

Pedrick Perfected Golden Beauty

Burpee's Golden Beauty,

Chester County Mammoth,

Hickory King,

Early Canada Yellow Flint,

Sugar Corn For Green Fodder,

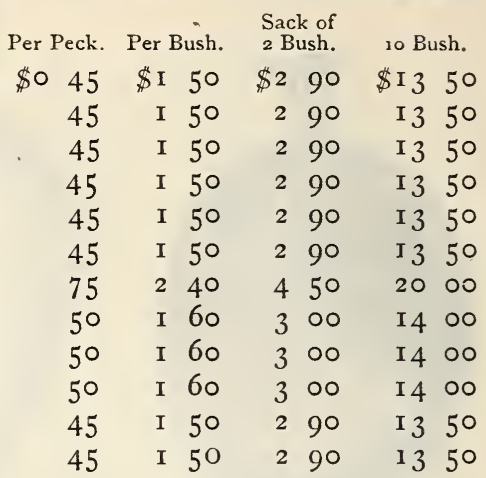

\section{CLOVER SEED.}

Subject to Fluctuations in Price.

Per $\mathrm{fb}$. $\$ 0$ I 5

Fluctuates. Fluctuates.

10

\section{EXTRA CLEAN GRASS SEEDS.}

Subject to Fluctuations in Price.

Herd, or Red Top (Agrostis vulgaris). (Sack of 50 lbs. \$3.75), Orchard (Dactylis glomerata),

Fancy Cleaned Kentucky Blue (Poa pratensis), .

Timothy (Phleum pratense), .

Sweet Vernal (Anthoxanthum odoratum), .

English Rye (Lolium perenne),

Italian Rye (Lolium Italicum),

Yellow Oat (Avena flavescens),

Hungarian Millet (Panicum Germanicum),

Golden, or German Millet, .

Per $\mathrm{tb}$. Per Bush.

$\$$ I IO

250

× 75

Fluctuates

$\$ 0 \quad 45$

I 50

I 75

I I 5

I I 5

East India, or Pearl Millet,

Crested Dogstail (Cynosurus cristalus),

Hard Fescue (Festuca durinscula), .

I 80

Meadow Fescue(Festuca pratensis),

Creeping Bent (Agrostis stolonifera), .

325

Johnson Grass (Sorghum halapense), .

275

Sheep's Fescue (Festuca ovina),...

I 80

Tall Meadow Oat (Avena elatior)

275

Wood Meadow (Poa nemoralis),.

Brom us Schroederi, or Rescue Grass, . . . . . . . . . . . 28

Hungarian Brome, or Awnless Brome (Bromus inermis), . . $\quad$ I8

240

30 


\begin{tabular}{|c|c|c|}
\hline Bush. & $\begin{array}{l}\text { Sack of } \\
2 \text { Bush. }\end{array}$ & $\begin{array}{c}\text { Per } \\
\text { ro Bush }\end{array}$ \\
\hline I 5 & $\$ 200$ & $\$ 9$ \\
\hline & I 70 & 8 \\
\hline & I 70 & 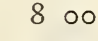 \\
\hline
\end{tabular}

MISCELLANEOUS.

Broom Corn, Improved Evergreen, .

Mammoth Russian Sunflower,

Silver Hull Buckwheat,

New Japanese Buckwheat,

Early Orange Sugar Cane,

Early Amber Sugar Cane,

Teosinte (Reana luxurians),

Soja Bean,

Dwarf Essex Rape,

Australian Salt Bush,

Kaffir Corn,
Per Qt. Per 4 Qts. Per Peck. Per Bush. Per $2 \mathrm{Bu}$.

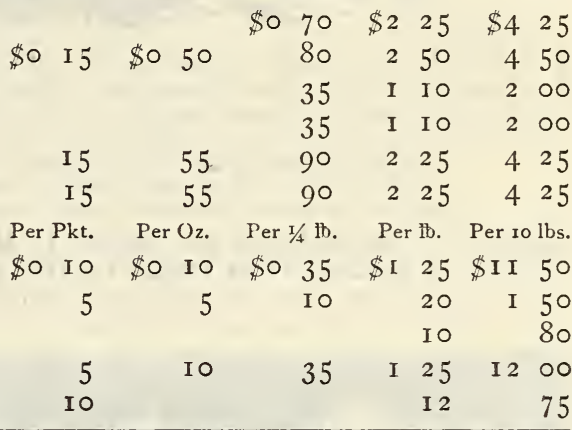

\section{Quantities of Seed Required in Garden and Field Culture.}

Quantity per acre.

Artichoke, I oz. to 500 plants, . . . 6 ozs. Asparagus, I oz. to 800 plants, . . . 2 lbs. Asparagus Roots, $4 \times 11 / 2$ feet, . about 8,000 . Beans, dwarf, I pint to Ioo ft. of drill, I I $/ 4$ bus. Beans, pole, I pint to Ioo hills, . . . . 1/2 "6 Beet, garden, I oz. to Ioo feet of drill, 4 lbs. Beet, Mangel, I oz. to Ioo feet of drill, 5 Broccoli, I oz. to 5,00o plants, . . . 2 Brussels Sprouts, I oz. to 5,000 plants, 2 Buckwheat, . . . . . . . $1 / 2$ bu. Cabbage, I oz. to 5,000 plants, . . . 2 ozs. Carrot, . . . . . . . . $2 \frac{1}{2}$ lbs. Cauliflower, I oz. to 5,000 plants, . . . $3 \frac{1}{2}$ ozs. Celery, I oz. to I5,000 plants, . . . . 2

Chicory,

Clover, Alsike and White Dutch, . . . I2

" Iucerne, . . . . . 20 to 30

" Crimson Trefoil, . . . . Io to I5

“ Large Red and Medium, . . I5

Collards, I oz. to 5,000 plants, . . . 2

Corn, pop (shelled), . . . . . 2 qts.

Corn, sweet, $1 / 4$ pint to Ioo hills, . . . I peck.

Cucumber, I oz. to Ioo hills, . . . I to 2 lbs.

Egg Plant, I oz. to 2,000 plants, . . 4 ozs.

Endive, $1 / 4 \mathrm{oz}$. to Ioo feet of drill,. . $4 \frac{1}{2} \mathrm{lbs}$.

Gourd, 2 ozs. to Ioo hills, . . . . .

Grass, Blue, Kentucky, . . . . . 35

"Hungarian and Millet, . . . . I

" Mixed Lawn, . . . . . 3 to 5

" Red Top,....... . . 42

" Timothy, . . . . . . . I5
Grass, Orchard, Perennial Rye, and

Quantity per acre.

Wood Meadow, . . . . about 3 bus. Horse Radish Roots, . . . . Io,000 to I5,000. Kale, I oz. to 5,000 plants, . . . . . 2 ozs. Kohl Rabi, $1 / 3$ oz. to Ioo feet of drill, 4 lbs. Leek, $1 / 3$ oz. to Ioo feet of drill, . . . 4 Lettuce, $1 / 4 \mathrm{oz}$. to Ioo feet of drill, . 3 Melon, Musk, I oz. to Ioo hills, . . . 2 IVater, 4 ozs. to Ioo hills, . . . 3 Nasturtium, 2 ozs. to Ioo feet of drill, I5 Okra, I oz. to Ioo feet of drill, . . . . IO Onion Seed, $\mathrm{I} / 3 \mathrm{Oz}$. to Ioo $\mathrm{ft}$. of drill, 4 to 5 " " ". for Sets, . . 50 to 60 " Sets, I quart to 40 feet of drill, 8 bus. Parsnip, I/2 oz. to Ioo feet of drill, . . 3 lbs. Parsley, $1 / 2$ oz. to Ioo feet of drill, . . 3 Peas, garden, I pt to Ioo ft. of drill, I to 3 bus. " field, . . . . . . . 2 to 3 Pepper, I oz. to I,500 plants, . . . 3 ozs. Pumpkin, I lb. to 200 hills, . . . 3 to 4 lbs. Radish, I oz. to Ioo feet of drill, Io to I2 Rape, Dwarf Essex, . . . . . 3 Salsify, I oz. to Ioo feet of drill, . . 8 Spinach, I oz. to Ioo feet of drill, . . , 8 Sunflower, . . . . . . . . 8 Squash, Summer, 4 ozs. to Ioo hills, . 3 bu. " IVinter, 8 ozs. to Ioo hills, 3 to 4 " Tomato, I oz. to 4,500 plants, . . . . 2 lbs. Tobacco, I oz. to 5,000 plants, . . . . 2 " Turnip, I oz. to 200 feet of drill, . I to 3 lbs. 


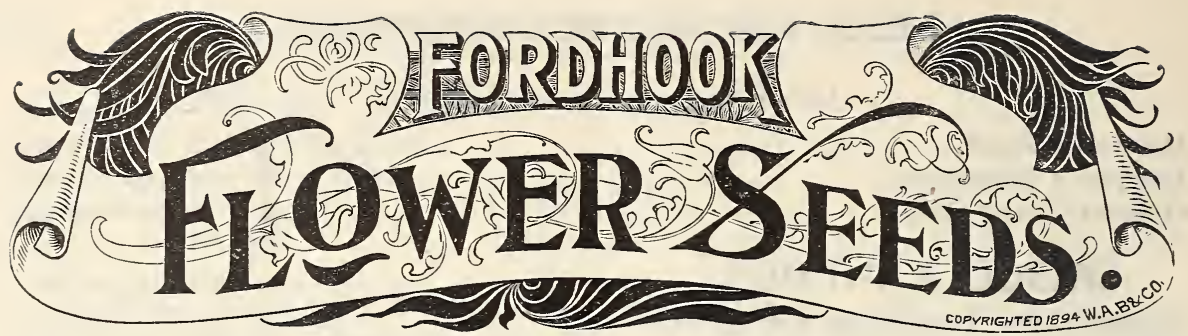

T $\mathrm{N}$ the following pages, beginning with SwEET PEAs, we offer, arranged alphabetically, the 1 leading flowers grown from seed, including many NEW AND SPECIAL FLOWERS of

unusual beauty. These seeds are all of the finest strains, and sure to give satisfaction.

We grow a larger area of Flower Seeds, and test all varieties more thoroughly on our own grounds, than do any other American seedsmen. An invitation to visit FoRDHOOK FARM on any week-day is always open to our customers. Iu the summer it is well worth traveling hundreds of miles to see the acres of Flowers and Trial Grounds.

ON all ORDERS for SEEDS IN RETAIL PACKETS WE ALLOW A DISCOUNT of THIRTY = THREE AND ONE=THIRD PER CENT. from the price quoted "per packet," as stated on second page cover.

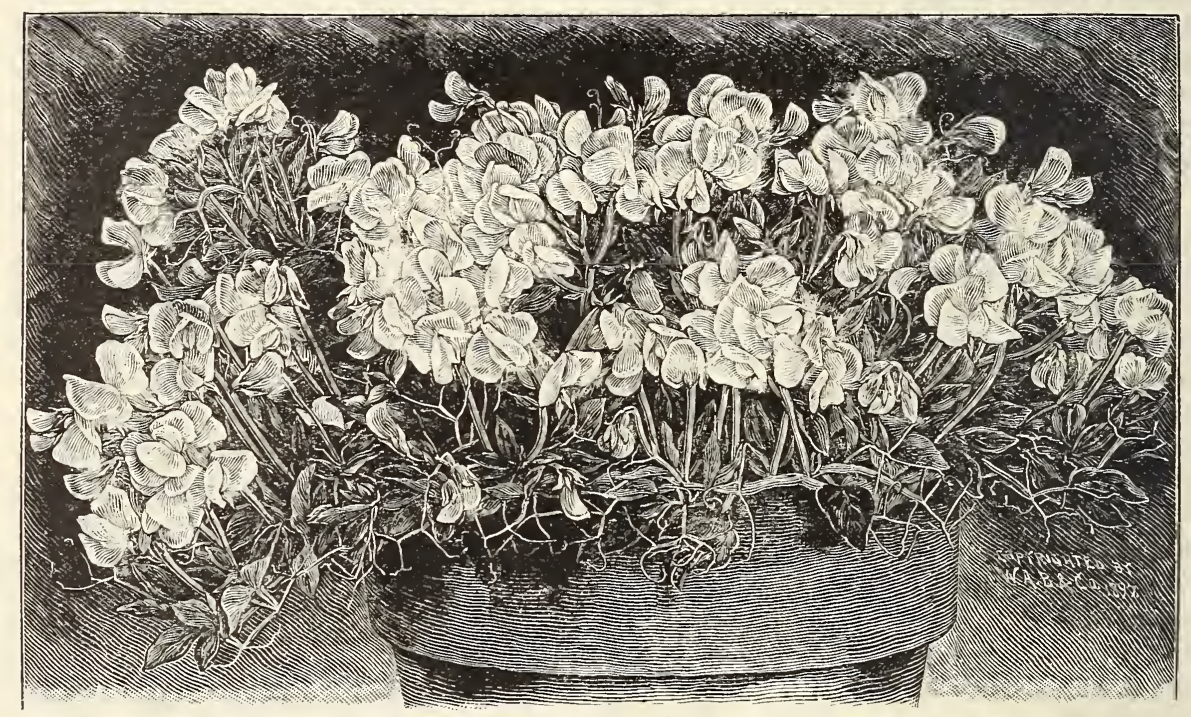

\section{Dwarf Sweet Pea,-Burpee’s PINK Cupid.}

The illustration above has been engraved accurately from a photograph of a single plant groun in ordinary field culture, lifted and set in a pot on a platform for the purpose of photographing on a level with the camera. Every

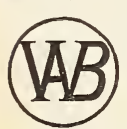

plant in our fields in "California, New York, and at FoRDHOoK FARM was absolutely true,-a perfect one and one-half inches across the standard-covering a silver dollar.

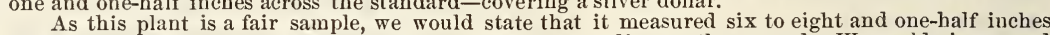
high by nineteen to twenty-four inches in diameter, spreading on the ground. We could give record of the number of flowers and buds, by actual count, ou a single plant of Burpee's PINK Cupid, but will merely refer to the extract on page 84 of BuRPEE's FARM ANNUAL FOR 1898, taken from THE FLorists' Exchange, in which the editor says, "We counted one hundred and twenty-one stalks in blossom on one plant and an average of three flowers to the stem."

Burpee's PINK Cupid is a hardy, black-seeded variety that grows vigorously everywhere. It is not a sport from the original White Cupid, but an actual departure from its parent, the tall Blanche Ferry. In habit and manner of growth it is strictly a Cupid, spreading from the root, from a foot to eighteen inches around, growing from six to eight inches high, and shooting up stems about six inches long, which bear, in full bloom at once, from three to four handsome large flowers, all borne close to the end of the stem.

In regular-size packets (each containing twenty-four seeds):

Per pkt. 25 cts.; 5 pkts. for $\$ 1.00$; per dozen pkts. $\$ 2.00$, postpaid.

In half-size packets (each containing twelve seeds):

Per pkt. 15 cts.; 10 pkts. for $\$ 1.00$, postpaid.

Directions for culture in English, German, and French printed upon each packet. 


\section{Complete List of SWEET PEAS.}

No other seedsmen in the world have devoted so much attention to SwEET PEAS. Our growing crops are rogued carefully and each variety is bred to the very highest standard.

By hundreds of thorough trials at ForDHook FARM, made every year, we know SWEET PEAS and the relative merits of all the different novelties as introduced annually. Keeping Purity and High Quality, rather than low prices, our first aim, we are recognized as

\section{Headquarters for Sweet Peas in America.}

Our Unequaled Collection now embraces one hundred and twenty=six varieties, exclusive of Eckford's Advance Set and the so-called "Double" sweet Peas.

Each is pure and true to name, - vastly superior to the "Cheap Seed" so largely grown without the proper care in the constant selection that is absolutely necessary to maintain first-class stocks.

Except where otherwise priced, all varieties are 5 cents per packet.

Adonis. Rose and carmine ; small flowers, . Per oz. $1 / 4$ tb. Per tb.

Alba Magnifica. Pure white flowers, . . . . . . . . . . . . . . $5 \quad 51030$

Alice Eckford. Rich cream-tinted standard; white wings, . . . . . $\quad 7 \quad 7 \quad 20 \quad 60$

America. The brightest blood-red striped, . . . . . . . . . . . . 641540

* American Seedlings. See description, page 32, . . . . . . . . . . $15 \quad 45150$

* Apple Blossom. Bright rose and pink; beautiful, . . . . . . . . 5512

* Aurora. Flaked orange-salmon; extra large, expanded standard, . . $\quad \begin{array}{llll}10 & 30 & 100\end{array}$

* Blanche Burpee. Eckford's largest pure white; unequaled, . . . . $\quad 7 \quad 7 \quad 20 \quad 75$

Blanche Ferry. The popular pink and white, . . . . . . . . . . 661535

Blanche Ferry,-Extra Early. Fully ten days earlier,. . . . . . $\quad 6 \quad 6 \quad 1540$

* Blushing Beauty. Very fine, delicate pink; hooded form, . . . . . $\quad 5 \quad 512 \quad 35$

Boreatton. Very dark maroon; self-colored, . . . . . . . . . $5 \quad 5 \quad 12$

Bride of Niagara. A fine semi-double form of pink and white, . . $\quad 7 \quad 20$

* Brilliant. New bright scarlet; does not burn, . . . . . . . . . . 1035

Bronze King. Standards of a terra-cotta tint; wings ivory-white, . $\quad 5 \quad 15$

Bronze Prince. Standard maroon; wings purple ; poor form, . . . 5510

Burpee's Earliest of All. Pink and white. Per pkt. 15 cts., .. .

* Burpee's New Countess. The best lavender, . . . . . . . . . . . 10

Burpee's PINK Cupid. See preceding page. Per pkt. 25 cts.,

Butterfly. White, laced with lavender; notched standard, . . . . .

Captain Clark. White and lavender ; streaked carmine, . . . . . .

* Captain of the Blues. Purplish mauve and pale blue, . . . . . .

* Captivation. Beautiful light magenta or claret color,

Carmen Sylva. Purplish-carmine and lavender, shaded rose,

* Celestial. Delicate azure-blue ; a German novelty,

Columbia. White ground, suffused pink and purple ; small

Coronet. Small flowers; white, striped orange-pink, . . . . . . .

* Coquette. Primrose-yellow shaded with pale lavender, . . . . . . . 10

* Countess of Aberdeen. Self-colored soft pink, turning lighter, . .

* Countess of Powis. "A glowing orange, suffused with light purple."

Per pkt. 10 cts., .....................

* Countess of Radnor. Pale mauve or lavender, . . . . . . . . . 5

* Countess of Shrewsbury. Rose standard; white wings, . . . . . 10

* Creole. Pinkish-lavender and light lavender, . . . . . . . . . 10

* Crown Jewel. Primrose ground, veined with violet-rose, . . . . .

Crown Princess of Prussia. Flesh-colored and salmon-buff, . . . 5

Cupid. The first dwarf; growing only five inches high; pure white, . 10

Daybreak. Watered crimson-scarlet on white ground, . . . . . .

Delight. White, slightly crested with crimson; very small flowers, .

* Dolly Varden. Shaded bright purple-magenta. Per pkt. 15 cts., . .

* Dorothy Tennant. Deep rosy-maure; beantiful, . . . . . . . . . 
* Duchess of York. White, delicately suffused with light pink,

Duke of Clarence. A brilliant shade of rosy-claret, . . . . . . . $6 \begin{array}{llll}6 & 15 & 40\end{array}$

Duke of York. Rosy-pink and white, . . . . . . . . . . . . . 64621540

Eliza Eckford. Standard rose ; wings delicately striped with rose, . $\begin{array}{llll}5 & 12 & 35\end{array}$

* Emily Eckford. Standard light reddish-mauve; wings a true blue, $\begin{array}{llll}7 & 20 & 55\end{array}$

Emily Henderson. White; blooms early and profusely, . . . . . $6 \begin{array}{llll}6 & 15 & 35\end{array}$

Empress of India. Rosy standard ; white wings ; of small size, . . $\quad 5 \quad \begin{array}{lll}5 & 12 & 35\end{array}$

Etna. Brownish-crimson and violet; small and unattractive, . . . . $\quad 5 \quad 5 \quad 12 \quad 35$

Fairy Queen. White, shaded rose and violet; small size, . . . . . $\quad 5 \quad 5 \quad 10 \quad 30$

Firefly. A deep, brilliant scarlet; truly a fiery shade, . . . . . . $\begin{array}{lllll}7 & 20 & \mathbf{7 0}\end{array}$

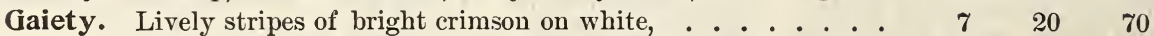

Golden Gate. Pinkish-mauve and lavender; upright wings, . . . . $\begin{array}{cccc}10 & 30 & 00\end{array}$

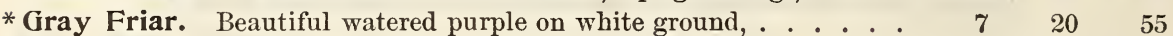

* Her Majesty. Bold flowers of a most beautiful rose color, . . . . . $\quad 7 \quad 7 \quad 2060$

Ignea. Intense scarlet-crimson; liable to burn, . . . . . . . . . 6645

Imperial Blue. Blue, shaded mauve, . . . . . . . . . . . . . $55 \quad 5 \quad 10 \quad 30$

Indigo King. Maroon, nearly indigo ; staudard notched at sides, . . $\begin{array}{llll}5 & 12 & 35\end{array}$

Invincible Carmine or Cardinal. Shining crimson-scarlet, . . . . $\quad \begin{array}{llll}5 & 12 & 35\end{array}$

Invincible Red Striped. White, striped on scarlet, . . . . . . . $\quad 5 \quad 5 \quad 12 \quad 35$

Invincible Scarlet. The old scarlet, .............. . $5{ }^{2} 10 \quad 30$

Isa Eckford. White, suffused rosy-pink, . . . . . . . . . . . $5512 \quad 35$

* Juanita, or Striped Celestial. White ground, striped lavender, . . $\quad 7 \quad 20 \quad 55$

* Katherine Tracy. Soft but brilliant pink, . . . . . . . . . . . . 501235

Lady Beaconsfield. Standard salmon pink ; wings primrose-yellow, $\quad \begin{array}{llll}6 & 15 & 45\end{array}$

* Lady Penzance. Standard orange-pink ; wings deep, pure pink, . . $6 \begin{array}{lll}6 & 15 & 45\end{array}$

Lemon Queen. Delicate blush, tinted lemon, . . . . . . . . . . 551235

Light Blue and Purple. One of the oldest, . . . . . . . . . . $\quad 5 \quad 51030$

* Little Dorrit. Pink standard ; white wings, . . . . . . . . . . $7 \quad 7 \quad 20 \quad 55$

* Lottie Eckford. White ground, suffused with lavender-blue, . . . $6 \begin{array}{llll}6 & 15 & 35\end{array}$

* Lottie Hutchins. Cream color, flaked pink. Per pkt. 15 cts.

* Lovely. Soft shell-pink. Truly most "lovely," . . . . . . . . . $10 \quad 35125$

Madame Carnot. Mauve standard ; blue wings ; small, . . . . . $6 \begin{array}{llll}6 & 15 & 45\end{array}$

* Maid of Honor. White, edged violet. See page 116, . . . . . . . $10 \quad 30100$

* Mars. Eckford's new bright scarlet; large and well-formed, . . . . $\quad \begin{array}{lll}10 & 35 & 125\end{array}$

Mauve Queen. Standard mauve; wings light blue, . . . . . . . $\quad 5 \quad 5 \quad \begin{array}{lll}5 & 12 & 35\end{array}$

* Meteor. Standard bright orange-salmon ; wings pink, veined, . . . $7 \begin{array}{llll}7 & 20 & 70\end{array}$

Mikado. Cerise ground, veined with white stripes, . . . . . . . . $7 \begin{array}{llll}7 & 20 & 55\end{array}$

Miss Hunt. Standard pale carmine salmon ; wings soft pink, . . . $\quad \begin{array}{llll}5 & 12 & 35\end{array}$

* Modesty. White, suffused light pink. Per pkt. 15 cts.

* Monarch. Deep bronzy-maroon and dark blue, . . . . . . . . . . $77 \begin{array}{lll}7 & 15 & 40\end{array}$

* Mrs. Eckford. Beautifully shaded primrose-yellow, . . . . . . . $6 \begin{array}{llll}6 & 15 & 45\end{array}$

Mrs. Giladstone. A lovely soft pink, . . . . . . . . . . . . $55 \quad 512 \quad 35$

* Mrs. Jos. Chamberlain. Striped, bright rose on white, . . . . . $747^{2} \quad 60$

Mrs. Sankey. Flowers white ; seeds black, . . . . . . . . . 551235

Novelty. Standard bright orange-rose ; wings light mauve, . . . . $7 \begin{array}{llll}7 & 20 & 55\end{array}$

Oddity. Peculiar pale carmine and bright rose, . . . . . . . $77 \quad 7 \quad 20 \quad 60$

Orange Prince. Standard orange-salmon; wings bright piık, . . . $6 \begin{array}{llll}6 & 15 & 40\end{array}$

* Oriental. A greatly improved Lady Penzance. Per pkt. 15 cts.

Ovid. Rose-pink, margined with deeper rose, . . . . . . . . . 551235

Painted Lady. The old pink and white, . . . . . . . . . . . 551030

Peach Blossom. Standard salmon-pink; wings soft pink, . . . . . $6 \begin{array}{llll}6 & 15 & 45\end{array}$

* Prima Donna. A most lovely shade of soft pink, . . . . . . . . . $\quad \begin{array}{lll}10 & 35 & 125\end{array}$

Primrose. Pale primrose yellow, . . . . . . . . . . $55 \quad 5 \quad 12 \quad 35$

* Prince Edward of York. Scarlet and rose. Per pkt. 10 cts.

Princess Beatrice. A popular rosy-pink, 
Princess Louise. Standard rosy-pink; wings lilac-blue, . . . . \$0 05 \$0 $12 \$ 035$

Princess May. Light lavender ; flowers small, . . . . . . . . . . 6645

Princess Victoria. Standard bright scarlet; wings rosy-mauve, . . $\quad 6 \quad 6 \quad 15 \quad 45$

* Princess of Wales. Striped mauve on white ground, . . . . . . . $5 \begin{array}{llll}5 & 12 & 35\end{array}$

Purple Prince. Standard maroon, shaded bronze; wings purple, . . $\quad 5 \quad 5 \quad 12 \quad 35$

Queen of England. Pure white; notched at top of standard, . . . $\quad \begin{array}{llll}5 & 12 & 35\end{array}$

Queen of the Isles. White stripes on bright crimson-scarlet, . . . $\quad \begin{array}{llll}5 & 12 & 35\end{array}$

* Queen Victoria. A beautiful soft yellow. Per pkt. 10 cts.

* Ramona. White, daintily splashed with pale pink, . . . . . . . . $7 \quad 7^{2} 2060$

Red Riding=Hood. Rosy-pink ; standard closely overlaps the wings, $\quad \begin{array}{llll}7 & 20 & 55\end{array}$

Rising Sun. Orange and rose, shaded carmine; small, "old style," $\quad 6 \quad 15 \quad 45$

* Royal Robe. Standard rich but delicate pink ; wings soft blush-pink, $\begin{array}{llll}6 & 15 & 50\end{array}$

* Royal Rose. Deep rosy-pink ; immense size. Per pkt. 10 cts., . . $\quad \begin{array}{lll}10 & 35 & 125\end{array}$

* Salopian. Deep crimson and orange-scarlet. Per pkt. 10 cts.

Scarlet Striped. One of the oldest varieties, . . . . . . . . . . . $50 \quad 5 \quad 10 \quad 30$

* Senator. Bright brown and chocolate, shaded and striped on white, . $\quad \begin{array}{llll}6 & 15 & 40\end{array}$

* Sensation. Cream-color standard ; white wings. Per pkt. 15 cts.

* Shahzada. Rich maroon and dark purple. Per pkt. 10 cts.

* Splendid Lilac. Light lilac ; now an "old style".flower, . . . . . $55 \quad 5 \quad 12 \quad 35$

* Splendor. Superb bright rose, shaded crimson, . . . . . . . . . . 64041540

* Stanley. Rich dark maroon. "This is by far the finest dark variety," $\quad 6 \quad 15 \quad 45$

* Stella Morse. The best primrose-yellow. Per pkt. 15 cts.

The Queen. Mauve and pink; small size, . . . . . . . . . . $54 \quad 12 \quad 35$

* Triumph. Enormous bright orange-pink. Per pkt. $10 \mathrm{cts}$.

* Venus. Lovely salmon-buff, shaded rosy-pink, . . . . . . . . . $66^{6} 1545$

Vesuvius. Violet, with dull crimson spots, . . . . . . . . . . . $6415 \quad 35$

Violet Queen. Standard mauve; wings light violet, . . . . . . 551235

* Waverly. Standard rosy-claret; wings light blue, . . . . . . . . $5 \quad 12 \quad 35$

* Wawona. New striped Heliotrope. Per pkt. 15 cts.

White. The old pure white ; notched at top of standard, . . . . . $55 \quad 5 \quad 10 \quad 30$

All Sweet Peas, 5 cts. per packet, except where otherwise priced.

*The varieties marked with an asterisk (*) produce flowers of good substance and largest size-being of the true grandiflora type. All these are entirely free from notches either at top or side of the standard. Some of the other Sweet Peas are very fine,-of large size and beautiful color, but for one reason or another are not, according to our critical standard, entitled to be starred. For instance, DAYBrEak is beautiful and of good size, but like America and Emily Henderson, has a slight notch at top of the standard.

\section{SWEET PEAS in Mixtures.}

"Cheap" Per oz. $1 / 4 \mathrm{tb}$. Per $\mathrm{fb}$.

"Cheap" Mixed (10 ibs. @ 15 cts. per tb), ......... . \$0 $03 \$ 010 \$ 018$

All Colors Mixed. The best for the money, . . . . . . . . . $5{ }^{2} 10 \quad 25$

New Sweet Peas Mixed. A very good mixture, . . . . . . . . . $50 \begin{array}{lll}5 & 10 & 30\end{array}$

Eckford's New Sweet Peas, Finest Mixed, . . . . . . . . . . $\quad 5 \quad 5 \quad 1030$

Eckford's Gilt Edge, or Surpassing Sweet Peas Mixed, . . . . $\quad 7 \quad 7 \quad 20 \quad 70$

Eckford's Up=To=Date. See next page. (Four 1-oz. packages for 65 cts.)
Burpee's Best Mixed. See next page, . . . . . . . . . . . . 20

Burpee's American Seedlings. See next page, . . . . . . . $15 \quad 45 \quad 150$ NEW DOUBLE SWEET PEAS. We do not consider these so beautiful as the expanded but not more the most carefully selected stock seed, saved only from the best plants bearing double flowers, we offer the following varieties :

$\begin{array}{llll}\text { Apple Blossom, } & \text { White, } & \text { Lottie Eckford, } & \text { Senator, } \\ \text { Butterfly, } & \text { Waverly, } & \text { Captain of the Blues, } & \text { Splendor. } \\ \text { Duke of Clarence, } & \text { Boreatton, } & \text { Bride of Niagara, } & \end{array}$

Each of the above DOUBLE SWEET PEAS at $5 \mathrm{cts}$. per pkt.; $7 \mathrm{cts}$. per $0 z$.; $20 \mathrm{cts}$. per $1 / 4 \mathrm{lb}$.; $60 \mathrm{cts}$. per Ib.

Eleven Mixed DOUBLe SWEET PEAS : Pkt. 5 cts.; oz. 7 cts.; $1 / 4$ lb. 20 cts.; per lb. 60 cts. 


\section{SWEET PEAS FOR 1898.}

The Most Complete Collection in the World.

W. AtLee Burpee left on Monday last for California, where he will spend a month inspecting seed crops, principally sweet peas. Mr. Burpee says that although we have been passing through such depressed business conditions, his firm's sales of sweet pea seed have been eight thousand pounds more than last year, and with fair crops this season they will have over 50,000 pounds of sweet peas in their warehouse next fall. Mr. Burpee expects to return from California late in June, and after going through his own trials of sweet peas will sail for Europe early in July, and will visit Henry Eckford, in Shropshire, about the middle of July, when this well-known sweet pea specialist will have his crops in full bloom. These trips of Mr. Burpee will amount to over $13,000^{\circ}$ miles travel in the interest of sweet peas. - From THE FLoRISTs' ExсHANGE, New York, May 22, 1897.

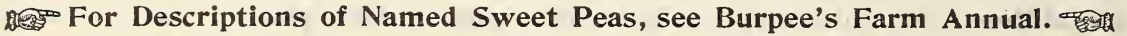

\section{Three Grand New Mixtures of SWEET PEAS,}

\section{Which Cannot be Had of Equal Quality Elsewhere.}

\section{Sweet Peas,-Burpee's AMERICAN SEEDLINGS.}

By crossing and recrossing the finest new Sweet Peas of the improved large-flowering type there occurred the most remarkable "break," which we offered in mixture for the first time last

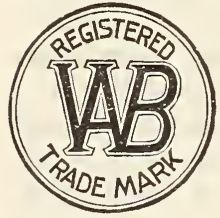

derful substance. year as BuRPEE's New AMERICAN SEEDLINGs. They embrace superb new varieties not yet named,-all of the largest size, finest form, and of the most beautiful colorings.

Among the shades and colors, which are distributed quite evenly, is one of an almost true orange, another of lemon blush, while others are of pure cream, lemon, lemon tiuted with blush, orange-red, salmon-buff, also salmonbuff with pink edge, blue-edged, light lavender, and all shades of pink from very light (nearly white) to the richest deep-rose color.

All the flowers are of fine expanded form, very largest size, and of wonflowers are borne in profusion, three and four on a stem.

Per pkt. 10 cts.; oz. 15 cts.; 2 ozs. 25 cts.; $\frac{1}{4}$ lb. 45 cts.; per lb. $\$ 1.50$.

\section{Eckford's New "UP-TO-DATE" Mixed Sweet Peas.}

When we had the pleasure of visiting his garden at Wem, Shropshire, England, last July, Mr. HENRY ECKForD kindly agreed to supply us this season for our retail trade, the best seed of his own growing. This is identically the same quality which he described as follows in his retail catalogue for 1897 :

\section{ECKFORD'S GIANT SWEET PEAS IN MIXTURE}

Contains a great variety of most charming colors, only obtainable direct from Henry Eckford, and is VERY STRONGLY RECOMMENDED for forming long hedges or screens.

PER PACKET 10 CTS.; PER OUNCE 20 CTS.; three ounce packages for $50 \mathrm{cts}$.

\section{"BURPEE'S BEST" Mixed-Gíant New Sweet Peas.}

This mixture of Sweet Peas, as improved for 1898, is undoubtedly the finest ever offered. It contains only grand new named varieties of the large-flowering type. The seed of each has been grown separately from selected stock, and only the largest-flowered, most beautiful new

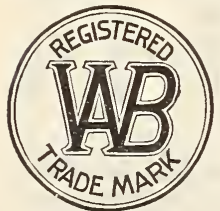
Sweet Peas have been selected and mixed by ourselves. As an example of the high standard at which we have aimed, we would state that all the White Sweet Peas grown from this seed will be the famous BLANCHE BuRPEE and all the bright scarlets of the new BuRPEE's "BRILLIANT" and ECKForD's MARs, while all the light lavenders, exclusively of BURPEE's NEw Countess.

This mixture contains also a suitable proportion of BURPEE's SENSATION, S'tella Morse, Lottie Hutchins, Dolly Varden, Modesty, and OrIENTAL, as well as Eckford's new large-flowered Salopian, Prince Edward of York, Queen Victoria, Countess of Powis, and Triumph-all NOVELTIES for 1898, as described on the pink paper pages. It includes also the finest introductions of 1897 (of the large-flowered type)-Aurora, Creole, Maid of Honor, Coquette, Lovely, Prima Donna, and Royal Rose. We have maintained a similar high standard throughout, and can assure all lovers of Sweet Peas that never before has it been possible to obtain "only the best" and all the best of the new large-flowering Sweet Peas as in this unequaled mixture, "BURPEE'S BEST."

Per pkt. 10 cts.; oz. 20 cts.; 2 ozs. 35 cts.; $\frac{1}{4}$ lb. 60 cts.; per lb. $\$ 2.00$. 


\section{OTHER FLOWER SEEDS.}

ABUTILON.

$\begin{array}{cc}\text { PER } & \text { PER } \\ \text { PKT, OZ. } & \text { OZ }\end{array}$

Royal Prize, Mixed, . (Trade pkt., \$1.00) $\$ 010 \quad \$ 700$ Mexicanum, ............. 5 Albiflorum,....... 5

Tom Thumb, Mixed, . . . . .

ALYSSUM.

Benthami (Sweet Alyssum), . . . . . . 5 Compactum (Tom Thumb), . . 5 Little Gem, . . . 10

Saxatile Compactum, ........ 5

\section{ASTERS.}

German Quilled, Mixed, ....... Betteridge's Prize, Mixed, . . . . . . 5

Cocardeau, or Crown, Mixed, ..... 10

Comet, Mixed (New), . . . . . . . 10 " Giant White, . . ( $1 / 4 \mathrm{oz}, 75$ cts.) " " Mixed,

Diamond, Mixed, . . . ( (1/4 oz., 60 cts.) Dwarf, Chrysanthemum-flowered, Mixed,

" Bouquet, Mixed, . . . . . . .

“ Pæony-flowered Perfection, Mixed,

$$
\text { " " " " Separate Colors, }
$$

“ Queen, White, .. ( $1 / 4$ oz., 75 cts.)

" " Crimson, . (1/4 oz., 75 cts.)

“ Finest Mixed (1/4 oz., 60 cts.)

Mary Semple Branching, . ( $1 / 4$ oz., 35 cts.) New White Branching, . ( $1 / 1 / 4$ oz., 35 cts.) Semple's Branching, Mixed,

Queen of the Market,

Queen of Spring, Mixed, ........

Triumph (New), . . . . (1/4 oz., 60 cts.)

Truffaut's Pæony-flowered Perfection,

Mixed, . . . . . . (1/4 oz., 35 ets.)

Truffaut's Pæony-flowered Perfection, Separate Colors, . . . ( (1/40z., 50 cts.), Each, Victoria; Mixed, . . . . (1/4 oz., 50 cts.) Fine Mixed, all Colors, . . . . . . . . . Fordhook Farorites, Mixed (1/4 oz., 35 cts.)

\section{BALSAM}

Burpee's Superb Camellia-flowered, Mixed, Daisy Miller, .... Perfection Pink, .... White,

Pure White, ..... Sunshine,

Defiance, Splendid, Mixed, . . . 10

Camellia-Howered, Mixed, . . . . . . .

BEET (Ornamental Foliage).

Chilian Scarlet Ribbed, ....... 5

$$
\text { "Yellow }
$$

Dracæna Leaf, . . . . . . . . . . .

\section{BELLIS (Double Daisy.)}

Extra Double White, . . . (1/4 oz., 75 cts.) 5

Longfellow, . . . . . ( (1/8 oz., $50 \mathrm{cts})$.

New Double Snowball, . . ( $1 / 8$ oz., 50 cts.) 10

German Double, Mixed, . (1/8 oz., 30 cts.) 5

Giant Flowered White (Trade pkt., 50 cts.) 15

\section{CALCEOLARIA.}

Hybrida, Mixed, . . . (Trade pkt., 50 cts.)

\section{CALENDULA.}

Double, Mixed (Pot Marigold), . . . . .

Meteor,

Oriole, Bright Yellow,

Prince of Orange, . . . . . . . .

The Royal Marigold, Trianon, .....

5

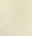

5

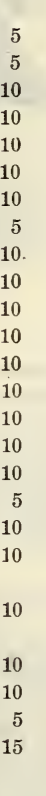

10
10
10
10
10
10
10
5

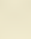

5

5

25

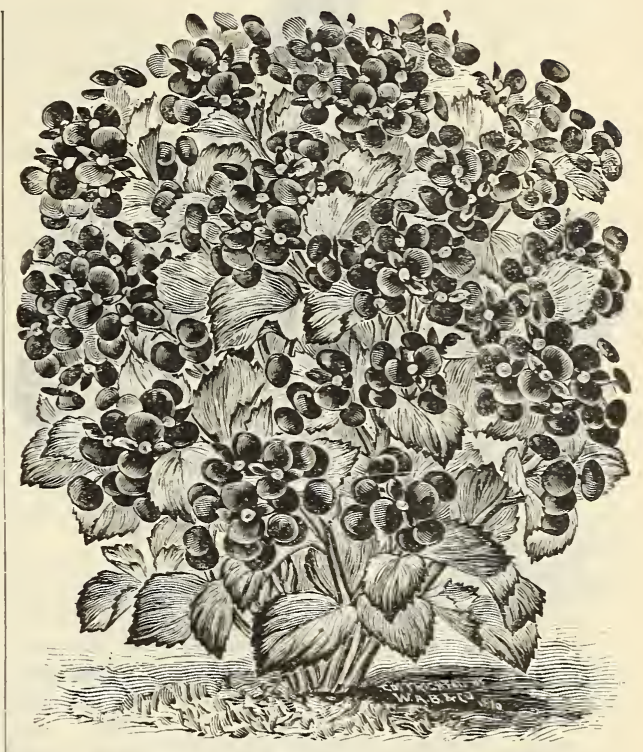

BURPEE'S NEW BEGONIA,-VULCAN.

\section{BEGONIA.}

PER PER

Erfordia, ..... (Trade pkt., $\$ 1.00) \leqslant 010$

175 Fordhook Giguntic Tuberous-rooted $\mathrm{Hy}$ -

200 brids, Single Mixed, (Trade pkt., 75 ets.) 25

Tuberous-rooted,Double (Trade pkt., \$1.00) 25

135 Large-leared, Rex,. . (Trade pkt., \$1.00) 15

Schmidti, ...... (Trade pkt., 75 cts.) 10

175 Vernon, ...... (Trade pkt., 50 cts.) 10

175 Vulcan, ...... (Trade pkt., \$1.00) 15

60

125

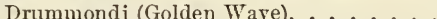

$\begin{array}{rr}7 & 75 \\ 1 & 10 \\ 1 & 10\end{array}$

110

100

75

125

225

35

10

15

Giants of California Marguerite,...

Perpetual, or Tree, Mixed,

\section{CARNATION.}

Choice Double, Mixed, . . (1/4 oz., 35 cts.) $10 \quad 100$

German, Extra Fine, Double, Mixed,

$$
\text { ( } 1 / 4 \text { oz., } 75 \text { cts.) k5 } 250
$$

Marguerite (1/8 oz., 25 cts. ; $1 / 4$ oz., 30 cts.) $10 \quad 100$

250

250

(Trade pkt., $50 \mathrm{cts}$ ) $\quad 25 \quad 250$

Picotee, Fine Double, Mixed (1/80z., 50 cts.) $15 \quad 300$

Fancy, Extra Fine, Mixed,

(Trade pkt., 50 cts.)

25

CANDYTUFT (Iberis).

Extra Dark Crimson, . . . . . . . . $5 \quad 510$

New Carmine. ............. 5.50

New Empress, . . . . . . . . . . $10 \quad 25$

Rocket, .........(Per lb., 75 cts.) 50

White,............... 5010

Giant Hyacinth-flowered (Trade pkt., \$1.00) 10

CANNA (Indian Shot).

10 Crozy's Dwarf, Mixed, . . . (Per $\mathrm{D}, \$ 2.00) \quad 10 \quad 20$

10 Mixed, . . . . . (Per $\mathrm{fb}, \$ 1.25) \quad 5 \quad 10$ 


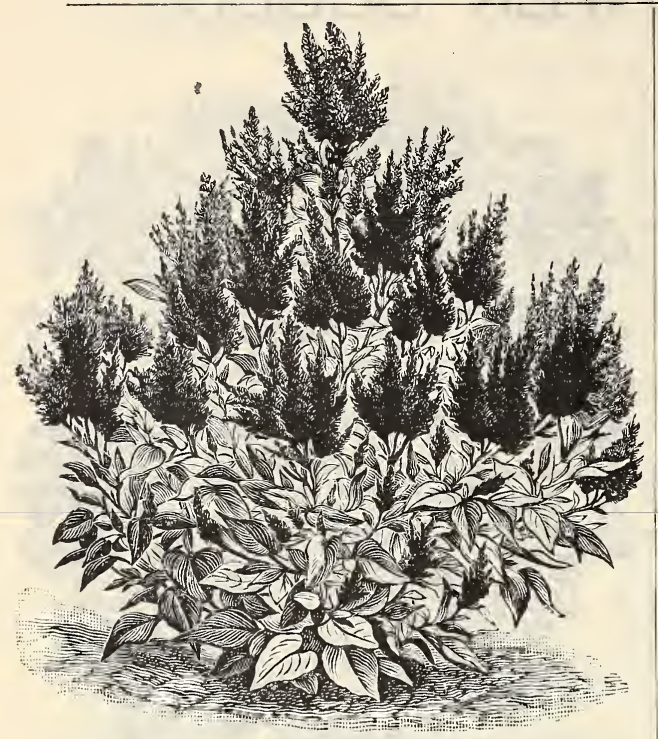

NeW Plumed CelosiA,-Triumph of the Exposition.

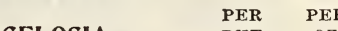

Cristata (Cockscomb), Dwarf, Mixed, ... \$0 $05 \quad \$ 0 \quad 50$

"Q Queen of Dwarfs, (1/4. oz., 30 cts.) 10

Triumph of the Exposition, (1/4 oz., 50 cts.) 10

\section{CENTAUREA.}

Candidissima, . . . (1000 seeds, 50 cts.) 15 Cyanus, Mixed (Blue Bottle), . . . . . 5 " fl. pl., Mixed, . . . . . . . 10

Victoria,. . . . . (Trade pkt., 40 cts.) 10

Marguerite, $(\mathrm{New}),$. . (Trade pkt., $50 \mathrm{cts}$.) 10

\section{CHRYSANTHEMUM.}

Coronarium, Mixed, ......... Frutescens (Paris White Daisy), . . . . . Indicum, . . . . . . (1/4 oz., 50 cts.) Inodorum Plenissimum, ........ Perennial Varieties, Mixed, $\left(\frac{1}{16}\right.$ oz., $\left.\$ 1.00\right)$ Tricolor, Eclipse, Golden Feather,

Annual Varieties, Single, Mixed,

\section{CINERARIA.}

There are no strains of Cinerarias offered better than ours. We recommend especially our large-flowering strain as being the best seed obtainable; it is grown for us in England by Mr. James Dovglas, PER PER Hybrida, Large-flowering; Finest, Mixed,

(Trade pkt., 75 cts.) $\$ 025$ Hybrida, Fine, Mixed (Trade pkt., 50 cts.) 15 Hybrida, Double, Extra Choice, Mixed, (Trade pkt., 75 ets.)

Maritima, (Dusty Miller), .......

\section{COLEUS.}

Our Sunset Strain produces plants fully equal in the coloring of the leaves to the best named varieties.

$\begin{array}{cr}\text { Fancy Fringed and Laciniated, } & \text { PER } \\ \text { (Trade pkt., } 75 \text { cts.) } & \$ 015\end{array}$ Sunset Strain of Large-leaved Varieties,

(Trade pkt., 65 ets.) 15

Mixed,

... ( $1 \frac{1}{16}$ 0z., 75 cts. $)$

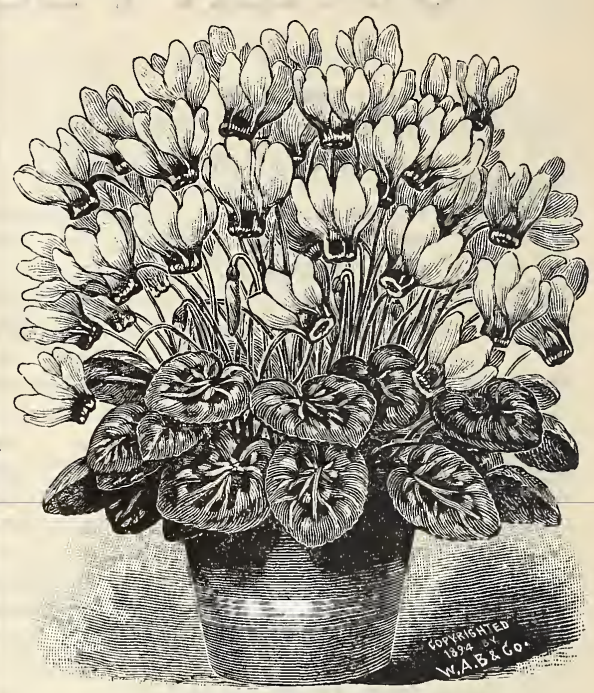

OYCLAMEN PERSICUM

COSMOS. PER PER

Bipinnatus, Mixed, . . . . . . $\$ 005 \$ \$ 25$

Hybridus, White, .......... 5

Pink . . . . 5

Giant Pure White, . . . $10 \quad 50$

Giant Pure Pink, . . . . . $10 \quad 50$

Giant, Mixed, $10 \quad 40$

Mammoth Fancy, Mixed, . . $10 \quad 150$

10

30

Platycentra,..... (Trade pkt., 50 cts.) $\quad 15$

\section{CYCLAMEN.}

Persicum, Mixed, . . . (500 seeds, 75 cts.) $10 \quad 150$ Giganteum, . (500 seeds, \$1.00) 15
15

100 160

75

15

15

15

\section{Si}

\section{CYPRESS VINE (Ipomœa Quamoclit).}

Scarlet, White, or Mixed, . . . . Each, $5 \quad 15$

\section{DAHLIA.}

Choice Mixed Pompone, ....... $5 \quad 5150$

Extra Choice Large-flowering, Double, . . $\quad 10 \quad 200$

Extra Choice Selected Pompone, . . . . $10 \quad 200$

Large-flowering, Double, Mixed, .... $5 \quad 100$

New Tom Thumb, Mixed, . . . . . . 10100

Striped Single,............ $10 \quad 75$

uperb Single, Mixed, Extra Fine, .... 10100

ingle, Mixed, ........... $10 \quad 40$

DIANTHUS.

Chinensis, Double, Mixed, ...... $5 \quad 5 \quad 20$

“ fl. pl., Re-selected, ..... $10 \quad 90$

Diadematus, fl. pl., ......... $5 \quad 75$

Heddewiggii, Finest Single, Mixed, . . . 5540 fl. pl., Mixed, ...... $5 \quad 55$

$\begin{array}{lll}\text { Mourning Cloak, . . . . . . } & 5 & 50\end{array}$

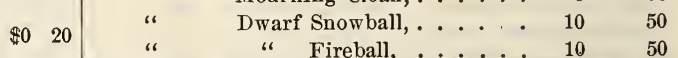

Imperialis, fl. pl., . . . . . . . . $5 \quad 5 \quad 25$

Laciniatus, Single, Mixed, ....... $5 \quad 5 \quad 35$

Nanus, New Hybrids, . . . . $10 \quad 175$

PER “ fl. pl., Mixed, ....... 5 . 55

oz. Large-flowered Dwarf Double Hybrid, . 10

Our Own Mixture of Many Varieties, . . . $5 \quad 5 \quad 45$

Fordhook Favorites, Mixed (1/4 oz., 20 cts.) $\quad 10 \quad 60$

Plumarius (Pheasant's Eye Pink), . . . $10 \quad 15$

Scoticus, fl. pl...... (Trade pkt., \$1.00) 10 
$\begin{array}{llr} & \text { PER } & \text { PER } \\ \text { DELPHINIUM. } & \text { PKT. } & \text { OZ. }\end{array}$

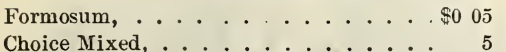

Hetrophylla, ........ 10

Marginata, .............. 5

\section{ESCHSCHOLTZIA.}

The Golden West, . . . . . . . . 10

Mandarin, :.......... 5

Mixed,

\section{FUCHSIA.}

Mixed, ......... (500 seeds, $\$ 1.50) \quad 15$

Procumbens (Trailing Fuchsia),

(500 seeds, \$1.50) 15

GAILLARDIA (Blanket Flower).

Fine Mixed, ........... 5

Picta Lorenziana, . . . . . . . . . 5

\section{GERANIUM.}

Apple Scented, . . . . (100 seeds, 25 cts. $) 25$ Fancy Pelargoniums, . (100 seeds, $75 \mathrm{cts})$. Finest Double, . . . . (100 seeds, \$1.00) 25 Zonale, Choice Mixed, . . . (1/4 oz., 25 cts.) 10

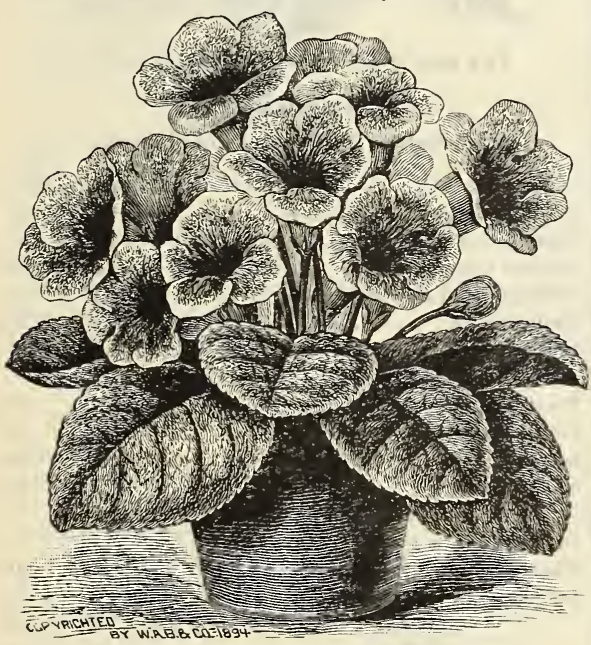

GLOXINIA HYBRIDA,-from Photograph.

\section{GLOXINIA.}

The seed offered is from our own saving at FORDHOOK FARM, and is a careful selection from erect, large-flowering varieties.

$\begin{array}{ll}\text { Lrect, Large-flowering, Best Mixed, } & \text { PER } \\ \text { PKT. }\end{array}$ (Trade pkt., $\$ 1.00) \$ 025$

New Giant-flowered Mixed, ....... 2 ๖

\section{GOURDS, Ornamental.}

Fine Mixed, ........... 5

Japanese Nest Egg (Pure), . . . . . . 10

\section{GYPSOPHILA}

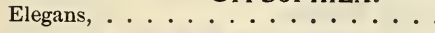

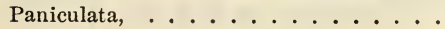

HELIANTHUS (Sunflower).

Globosus Fistulosus, .........

Miniature (Cucumerifolius), . . . . .

New Double Multiflora, .. (1/4 $\mathrm{fb}, 25 \mathrm{cts}$.)

The Dahlia,

100

30 15

$\$ 040$ Choice Mixed, . . . . . . . . . $\$ 010$

25 Dark Bouquet (New), (Trade pkt., 50 cts.) 10

Lady in White, ... (Trade pkt., $50 \mathrm{cts}$.) 10

15

For

5
Emperor, Mixed, 5
New Compact Blue, ... (1/4 oz., 80 cts.) 10

Mixed,

LATHYRUS (Perennial Peas).

Purple, ...........................

Splendens, ................... 15

White, ............ 10

LINARIA.

Cymbalaria (Kenilworth Ivy) (1/40z., $50 \mathrm{cts}$.) $\quad 10 \quad 150$

LOBELIA.

Erinus Compacta, ......... 5

" " Alba, ....... 5

" " Oculata, ....... 10

" Crystal Palace Compacta, . . . . . 5

" Star of Ischl, . . . . . . . . 10

"White Gem, .......... 10

" Mixed............. . . 5

\section{LYCHNIS.}

Chalcedonica, ........... 5

Haageana Hybrida,

\section{MARIGOLD.}

The Eldorado, or Dahlia-flowered, . . . . $5 \quad 5 \quad 25$

Lemon Queen, . . . . . . . . . . . 1030

French Double, Compact Gold Striped, . . 55

Dwarf Pulchra,..... $10 \quad 25$

Dwarf Pulchra,. . . $10 \quad 25$

Orange Ball, ..... . . $5 \quad 50$

Dwarf Mixed, ..... 5.

30

MIGNONETTE (Reseda Odorata).

Erfurt (New), ............... 1040

\$0 30 Giant Pyramidal (Extra Fine), . . . . 5

20 Improved Golden Queen, . . . . . . . 5

New Giant-flowered, Red, . . . . . . $10 \quad 40$

Odorata Grandiflora Ameliorata, .... 5

15 Parson's White Tree, . . . . . . . . 5

15 Pure Machet (Extra Fine Strain); . . . 50

Quaker City, ............ $10 \quad 75$

10 Sweet (the Common Mignonette), . . . . 5010

15 Golden Machet, . . . . . . . . . $10 \quad 50$

10 Allen's Defiance, . . . . . . . . . . $10 \quad 75$

10 Fordhook Finest Mixed, . . . . . . . . $10 \quad 50$ 
MER Mixed, ...........\$0 05 New Tom Thumb, Mixed, ...... 5 Variegated, ............ 5

\section{MATRICARIA.}

Eximia, Al. pl. (Feverfew), . . . . .

\section{MAURANDYA.}

Barclayana, . . . . . (1/4 0Z., 60 cts. $) ~ 10$

Fine Mixed, ........... 5

\section{MIMOSA.}

Pudica (Sensitive Plant), . . . . . . . .

\section{MIMULUS.}

Moschatus (Musk Plant), . . . . . . . . 5 Compactus (Trade pkt., 75 cts.) Tigrinus (Monkey Flower), . . . . . . . Grandiflorus (Trade pkt., 50 cts.)

\section{MOMORDICA.}

Balsamina (Balsam Apple), ...... Charantia (Balsam Pear), .......

\section{MOON FLOWER.}

Cross-bred, or Hybrid, . . . . . . . . 10

"Original" Variety, . . . . . . . . 10

New Pink, ................ 10

White-seeded, ........... 10

\section{MORNING GLORIES.}

New Imperial Japanese, Mixed Colors, . . 10 Tall Mixed (Convolvulvus Major), .... 5 Dwarf Mixed (Convolvulus Minor), . . . . 5

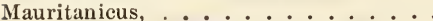

\section{MUSA ENSETE}

(Abyssinian Banana Tree). (100 seeds, \$1.25)

MYOSTIS $($ Forget $=\mathbf{m e}=\mathbf{n o t})$. Alpestris, Blue, .......... Alba, (White),...... 5

Eliza Fonrobert, ......... 10

NASTURTIUM, TOM THUMB.

Aurora, ............ 10

Brilliant Yellow, ......... 10

Bronze Colored, .......... 5

Brown-Red, ........... 10

Chameleon, ............. 5

Cloth of Gold, .......... . . 5

Compact Lustrous, . . . . . . . 10

Coruleum Roseun, ......... 5

Crystal Palace Gem, ......... 5

Empress of India, ......... 5

Gen. Jacqueminot, . . . . . . 10

Golden King, ........... 5

King of Tom Thumbs, . . . . . . 5

King Theodore, ..... 5

Lady Bird, . . . . . . . . . . . 5

Pearl, ............. 5

Prince Henry, ................. 10

Rose .................... 5

Ruby King, ............ 5

Scheuerianum Coccineum, ...... 5

Spotted King, ............ 5

Tom Thumb Beauty, ... . . . . 5

Mixed, . . . . . ( (1/4 $\mathrm{tb}, 30$ cts.; to, 75 cts.)

New, Mixed, . . . (1/4 to, 50 cts.; $\mathrm{tb}, \$ 1.75)$

Lilliput, Mixed, . . . . . .

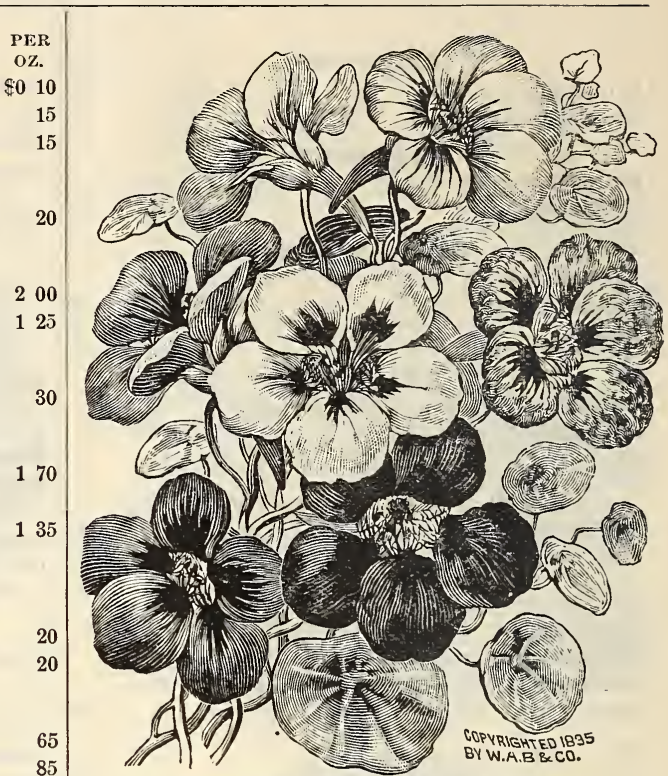

THE NEW HYBRIDS OF MADAME GUNTER.

NASTURTIUM, TALL

(Tropæolum Majus and Lobbianum). $\begin{array}{ll}\text { PER } & \text { PER } \\ \text { PKT. } & \text { OZ. }\end{array}$

Golden-leaved Scarlet, ........ 5

Heinemanni,............ 5

Luteum, ............ 5

Moonlight,............ 15

Pearl, .............. 5

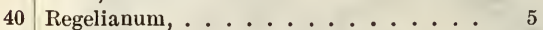

Scheuerianum,

" Coccineum, ...... 5

15 Sunlight, . . . . . . . . 15

Mixed Colors, . (1/4t $\mathrm{tb}, 25 \mathrm{cts}$; per th, $75 \mathrm{cts}$ ) 5

Lobbianum, Gold Garnet, ....... 5

Lucifer, ....... . 5

Spitfire, ....... 5

Cardinal, ........ 5

Crown Prince of Prussia, . . 5

Crystal Palace, ..... 5

Queen Victoria, ...... 5

Triumph d'Hyeres, ..... 5

du Prado,.... 5

Giant of Battles, ..... 5

King of the Blacks, 5

Finest Mixed,

$(1 / 4 \mathrm{tb}, 50 \mathrm{cts}$; per $\mathrm{tb}, \$ 1.75) \quad 5 \quad 15$

Hemisphæricum (Very Fine), ..... 5020

New Hybrids of Madame Gunter,

$(1 / 4 \mathrm{tb}, 60 \mathrm{cts}$; p per $\mathrm{tb}, \$ 2.00) \quad 10 \quad 20$

Fordhook Favorite Mixture,

$(1 / 4 \mathrm{tb}, 60$ cts.; per $\mathrm{fb}, \$ 2.00) \quad 10 \quad 20$

NICOTIANA.

Affinis (Ornamental Flowering Tobacco), . $10 \quad 25$

PERILLA.

$45 \mid$ Nankinensis, ........... 5 


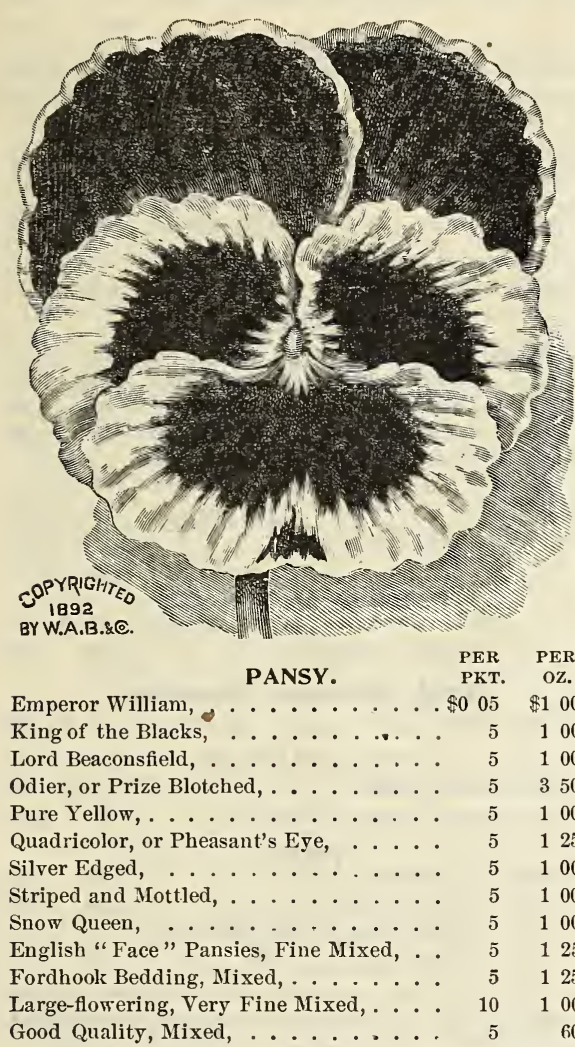

Good Quality, Mixed, . . . . . . 5 rate colors or the mixtures at 25 cts. each.

\section{PANSY, IMPROVED STRAINS.}

Bugnot, ........ (1/8 oz., \$1.00)

Burpee's Defiance, Mixed,

(Trade pkt., 70 cts.; $1 / 8$ oz., $\$ 1.00) \quad 15$

Burpee's Defiance, Separate Colors,

(Trade pkt. 70 cts.; $1 / 8$ oz., $\$ 1.25$ ) 15

Cardinal, ........... (1/8 oz., \$1.00) 10

Fire King, . ........ (1/8 oz., \$1.00) 10

Emperor Frederick, . . . . (1/8 oz., \$1.00) 10

Cassier's Giant Odier, . . (1/8 oz., 60 cts.) 10

Cassier's Hortense Rose, . . . . . . . . . 15

Coquette de Poissy, . (500 seeds, 45 cts $) \quad 10$

Giant Trimardeau, . . . . (1/4 oz., $60 \mathrm{cts}$.

" " Improved (1/8 oz., 50 ets.)

Imperial German, Mixed,

$$
\text { ( } 1 / 8 \text { oz., } 65 \text { cts.; } 1 / 4 \text { oz. } 1.10)
$$$$
\text { Separate Colors, }
$$

( $1 / 8 \mathrm{oz}, 75 \mathrm{cts}$.

Meteor, . . . . . . (1/8 oz., $70 \mathrm{cts}$.

Peacock, . . . . . . ( $1 / 8 \mathrm{oz}, 7_{0}$ cts. $)$

President Carnot, ........... 15

President McKinley, . . . . . . . 25

Rosy Morn, . . . . . ( (1/8 oz., $\$ 1.00) 10$

Victoria Red, . . . . . ( $1 / 8 \mathrm{oz}, 80$ cts. $) \quad 10$

Royal Prize, Mixed, of finest sorts,

( $1 / 8 \mathrm{oz}, 40 \mathrm{cts}$ ) $\quad 10$

\section{PLATYCODON.}

Grandiflora, Fine Mixed, .......

New Large-flowered, Dwarf, Blue, . . .
PETUNIA.

PER PER

Burpee's Defiance, Largest Flowering,

Finest Mixed. . . . . (Trade pkt., \$1.00) \$0 25

Dwarf Inimitable, . . . . . (1/8 oz., 35 cts.) 10

Fordhook Fancy Fringed, Double,

(Trade pkt., \$1.35) 25

Giant Emperor, . . . (Trade pkt., 50 cts.) 10

" Ruffled White, . (Trade pkt., $\$ 1.00) \quad 10$

“ Fringed White, . (Trade pkt., $\$ 1.00) \quad 10$

Giants of California, Mixed,

(Trade pkt., $\$ 1.00) \quad 15$

Large-flowering, Mixed, . . ( $\left.\frac{1}{16} \mathrm{oz} ., \$ 1.00\right) \quad 10$

Dwarf Brilliant Rose, . (Trade pkt., \$1.25) 10

Striped and Blotched, . . (1/4 oz., 25 cts.) 10

Hybrida, Mixed, . . . . . . . . 5 5

$\$ 075$

50

PHLOX DRUMMONDII.

Starred and Fringed, Mixed, . . . . . $10 \quad 75$

Fine Mixed, . . . . . . . . . . . . 554

Grandiflora Alba, . . . . . . . . $5{ }_{5} \quad 75$

Large Blood-Red, ..... $5 \quad 75$

100

$\begin{array}{rrrr}\text { Splendens, . . . . . . . . . } & 5 & 75 \\ \text { Fordhook Strain, . . . . . . } & 10 & 60\end{array}$

$\begin{array}{lllll}\text { Fordhook Strain, . . . . . . } & 10 & 60 \\ \text { Fine Mixed, . . . . . . . } & 10 & 50\end{array}$

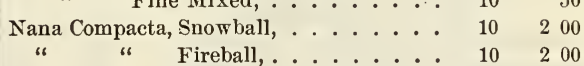

$\begin{array}{ll}2 & 00 \\ 1 & 50\end{array}$

Burpee's Fairy Blush, POPPY. ...... $10 \quad 80$

Carnation, Double, Mixed, . . . . . . $5 \quad 510$

Fordhook Fairy, Mixed, . . . . . . $10 \quad 100$

Golden Gate, . . . . . . . . . . 1040

Nankeen Yellow (New), ........ 10100

Snowdrift (True), . . . . . . . . 54

Tulip-flowered, .................. 10

The Shirley, . . . . . . . . . 5 . 50

Double Pæony-flowered, Mixed, . . . . 5510

\section{PORTULACA.}

Double Rose-flowered, Mixed,

$$
\text { ( } 1 / 8 \mathrm{oz}, 30 \mathrm{cts} .) \quad 10 \quad 200
$$

Finest Single, Mixed,....... 5 . 25

PRIMULA SINENSIS (Chinese Primrose).

The strain of Primulas we offer is the best. Florists can depend on the varieties being true to name, and the seed of the strongest germinating power. PER PER Auricula, ........ (1/4 oz., $\$ 1.25) \$ 0.15$

Fimbriata Filicifolia, Mixed (Fern-leaved

400 Primula), ...... (Tradepkt., $\$ 1.00) \quad 20$

Fimbriata, Fringed, Mixed,

(Trade pkt., 50 cts.)

200 “ Splendid, Mixed, Large-flower-

$350 \quad$ ing, . . (Trade pkt., 75 cts.) Alba Magnifica,

(Trade pkt., \$1.00)

Blue, ... (Trade pkt., $\$ 1.25$ )

Bright Red (Trade pkt., $\$ 1.00$ ) 20

Crimson Velvet,

(Trade pkt., $\$ 1.00)$

Kermesina Splendens,

(Trade pkt., $\$ 1.00) \quad 20$

Lilac Marbled,

(Trade pkt., $\$ 1.00) \quad 20$

Rosy Morn (Trade pkt., \$1.00) 20

Rubra Violacea,

(Trade pkt., \$1.00) 20

Snow Queen (Trade pkt., \$1.25) 20

Striped,. . (Trade pkt., \$1.00) 20

150 Obconica,...... (Trade pkt., 50 cents) 10 


\section{PYRETHRUM. PER}

Parthenifolium Aureum (GoldenFeather), \$0 10 Parthenium, fl. pl. (Feverfew), . . . . 10 Roseum (Insect Powder Plant), . . . . . . 10

\section{RICINUS (Castor Oil Bean).}

Cambodgensis, .............. 10

Spectabilis, . . . . . . . . . 5

Zanzibarensis, Mixed, . . . (1/4 $\mathrm{tb}, 50 \mathrm{cts}) \quad$.

Mĩixed, ....... (Per th, $\tilde{\mathrm{t}} 0$ cts.) 5

\section{SALVIA.}

Splendens (Scarlet Sage), . (1/4 oz., 35 cts.) 10

SCABIOSA (Mourning Bride).

Dwarf, Double Mixed, ......... 5

Large-flowered, Double, Mixed, . . . . . 10

Tall German, Mixed, . . . . . . . 5

\section{SMILAX.}

Myrsiphyllum Asparagoides,

SWEET WILLIAM (Dianthus Barbatus). Double, Mixed, . . . . . . . . . 5

Single, Mixed,. . . . . . . . . 5

\section{STOCK.}

Brompton, or Winter, Mixed, . . . . . . 10 Dwarf German 'Ten Weeks, Fine Mixed, . 5 Dwarf White Pyramid, . . . (1/8 oz., \$1.25) 15

Emperor, or Perpetual, Mixed, (1/8 oz., 60 ets.) 10

Giant Perfection, Mixed, . (1/8 oz., 30 cts.) 10 Globe Pyramidal, Mixed,. . . . . . . 1 Large-flowering Dwarf, Blood-Red, . . . . 10 Purple Violet, . . 10 Pure White, ... 10 Choice Mixed, . . 10 Red Victoria (New), . . . (1/8.0z., \$1.50) 15 White Perpetual, or Cut-and-Come-Again, 15

\begin{tabular}{|c|c|c|c|}
\hline $\begin{array}{l}\text { PER } \\
\text { OZ. }\end{array}$ & SALPIGLOSSIS. & $\begin{array}{l}\text { PER } \\
\text { PKT. }\end{array}$ & $\begin{array}{l}\text { PER } \\
\text { OZ. }\end{array}$ \\
\hline$\$ 040$ & Grandiflora, Finest Mixed, . . . . & 010 & $\$ 045$ \\
\hline 60 & Mixed, . . . . . . . & 5 & 30 \\
\hline 50 & TORENIA. & & \\
\hline 15 & $\begin{array}{l}\text { Fournieri, . . . . . (Trade pkt., } 50 \text { cts.) } \\
\text { " Grandiflora (Trade pkt., } 50 \text { cts.) }\end{array}$ & $\begin{array}{r}5 \\
10\end{array}$ & $\begin{array}{ll}3 & 50 \\
4 & 00\end{array}$ \\
\hline 15 & White Wings, . . . . (Trade pkt., 50 cts.) & 10 & 450 \\
\hline $\begin{array}{l}15 \\
10\end{array}$ & $\begin{aligned} & \text { Mixed, . . . } \text { THUNBERGIA. } \\
& \ldots \ldots \ldots \\
& \text { VERBENA. }\end{aligned}$ & 5 & 25 \\
\hline 125 & Hybrida, Auricula-flowered, . . . . . & 10 & 125 \\
\hline & Italian-striped, . (1/4 oz., 50 cts.) & 10 & 150 \\
\hline & Pure White, . . (1/4 oz., 40 cts. $)$ & 10 & 125 \\
\hline 15 & Scarlet Defiance, $(1 / 40 z ., 50 \mathrm{cts})$. & 10 & 150 \\
\hline $\begin{array}{l}40 \\
20\end{array}$ & $\begin{array}{l}\text { New Mammoth Fordhook Fa- } \\
\text { mous, Mixed Colors, }\end{array}$ & & \\
\hline 40 & $\begin{array}{l}\text { (1/4 oz., } 50 \mathrm{cts} .) \\
\text { Extra Fine, Mixed, }\end{array}$ & 10 & 175 \\
\hline & $\begin{array}{l}(1 / 4 \text { oz., } 35 \text { cts. }) \\
\text { Fine Quality, Mixed, }\end{array}$ & 10 & 125 \\
\hline 40 & (1/4 oz., $30 \mathrm{cts.})$ & 5 & 80 \\
\hline 15 & Common, Mixed, . . . . . . . & 5 & 60 \\
\hline & VINCA (Madagascar PeriwinkI & & \\
\hline 350 & Mixed Colors, . . . . . . . . & 5 & 65 \\
\hline 80 & WALLFLOWER. & & \\
\hline 425 & $\begin{array}{l}\text { Choice Single, Mixed, . . . . . . . } \\
\text { Fine German Double, Mixed, . . . . }\end{array}$ & $\begin{array}{r}5 \\
10\end{array}$ & $\begin{array}{r}15 \\
200\end{array}$ \\
\hline 225 & ZINNIA. & & \\
\hline 375 & Elegans, Superb Double, . . . . . . & 10 & 40 \\
\hline 250 & " Giant Mammoth, Mixed, . . . . & 10 & 50 \\
\hline 250 & Double Lilliput, (New Extra Fine & & \\
\hline 250 & S(rain), . . . . . . . & 10 & 70 \\
\hline $\begin{array}{l}150 \\
300\end{array}$ & \multicolumn{3}{|c|}{$\begin{array}{l}\text { Should you desire any other varieties offered in THE } \\
\text { FARM ANNUAL and not listed here, please write stating } \\
\text { quantity required, and we will quote prices by letter. }\end{array}$} \\
\hline
\end{tabular}

\section{SUMIMER-FLOWERING BULBS.}

The bulbs offered here are of the finest quality, being grown especially for us; they are all true to name, and are now properly stored in our warehouses awaiting orders.

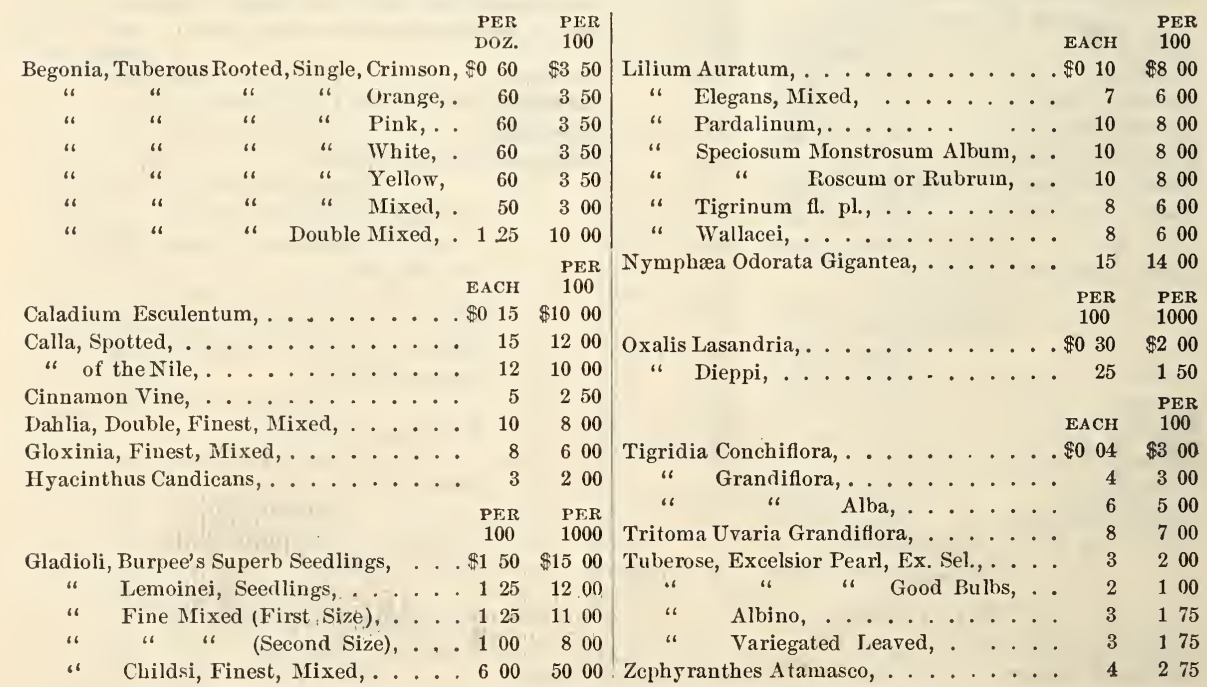




\section{Seven $S_{\text {weet }} P_{\text {eas for }} 25$ Cts.}

Never before has it been possible to offer such A Grand Collection of Seven Superb New Sweet Peas for twenty=five cents. All are regular-sized packets, containing from forty to seventy seeds each, except Queen Victoria and Shahzada, of which there are twenty seeds in each packet. Last year, without counting postage and trouble in sending to England, it would have cost more than two dollars to have gathered together the seed contained in these Seven Packets which are sold now for $25 \mathrm{cts}$.

BURPEE'S BRILLIANT. The color is of a rich, bright crimson-scarlet. The wings nearly equal the standard in intense richness of color.

BURPEE'S NEW COUNTESS. The flowers are of the largest size and pure light lavender throughout,-both on standard and wings.

COQUETTE. The wings are a clear primrose-yellow, while the large, expanded standard is shaded pale lavender on a primrose ground.

PRIMA DONNA. A most lovely shade of soft pink, of large size and fine form,-a great gem; frequently four flowers on a stem.

QUEEN VICTORIA. Color, soft yellow subtly overlaid with faint purple, imparting a luster most desirable but difficult to describe.

SHAHZADA. A decided advance in the direction of dark-colored sweet peas. Rich dark maroon with a shade of purple.

DOS- NotE.-Our seed of Eckford's Queen Victoria and Shahzada is grown from original sealed packets bought direct from Mr. Eckford last season at the retail price of $2 s$. 6d. per packet of twenty seeds.

NEW AMERICAN SEEDLINGS. This new strain, first offered in 1897, contains some beautiful new colors, and has been much admired.

\section{Cts.}

buys all the above,-Seven Superb packet, true to name as described briefly, and mailed, postpaid, to any address in the United States.

In the envelope containing each collection we enclose a new printed leaflet, giving both HENRY

ECKFORD's and the REv. W. 'T. HuTCHINS' instruc-

tions on How to Grow the Finest Sweet Peas.

Wholesale. We supply the above Collections at three for $\mathbf{5 0}$ price $15 \mathrm{cts}$. each, $-\$ 1.80$ per dozen or $\$ 15.00$ per 100 Collections.

\section{Eight Elegant Sweet Peas, 30 Cts.}

This Collection, neatly done up in a large envelope, with directions for culture, contains one full-size packet each of

AURORA. Extra large flowers, borne three on a stem; both standard and wings are flaked and striped with bright orange-salmon.

CAPTIVATION. 'This is really a new color in Sweet Peas; a glowing ruby-purple or bright claret. Large, shell-shaped stallard.

LOVELY. This is, indeed, lovely! It is a great acquisition. Grand flowers of very large size. Color, a most pleasing shade of shell-pink.

MAID OF HONOR. This can be deseribed as an Improved Butterfly. Beautiful flowers shaded and edged light blue on a white ground.

MARS. Eckford's New Scarlet. "Bright fiery erimson, deepening with age. A finely expanded, bold flower, of the most beautiful form.

ROYAL ROSE. The standards deep rosy-pink; the $\dot{w}$ ings are a most charming, light rosy-pink,-almost self-colored, of immense size.

STELLA MORSE. Decidedly the best of all the Sweet Peas, approaching primrose-yellow in color. One of the very finest of the nine magnificent New Sweet Peas now first introduced by us.

BURPEE'S BEST MIXED. Truly an unequaled mixture containing all the best novelties up to date. See page 32 .

With each Collection we enclose a copy of our new circular on How to Grow THE Finest SweET PEAS.

All of these are of the largest size, and improved "up-to-date" form, while STELla Morse can be had only direct from us, and alone costs 15 cts. per packet. Never before have we been able to include, in a cheap collection, a novelty the first year of its introduction.

For 30 Cts three dimes, or fifteen two-cent For 30 Cts., stamps, we will send the above Collection of Erght Elegant New Sweet Peas, postpaid, to any address in the United States or Mexico.

Wholesale. To florists and agents to sell again we supply the Tollections at $20 \mathrm{cts}$. each, 5 for $\$ 1.00$ or $\$ 2.40$ per dozen, postpaid. A9 This is in accordance with terms on second page cover, -a discount of one=third from retail prices on all seeds in packets. By express the price is $\$ 2.16$ per dozen or $\$ 18.00$ per 100 Collections.

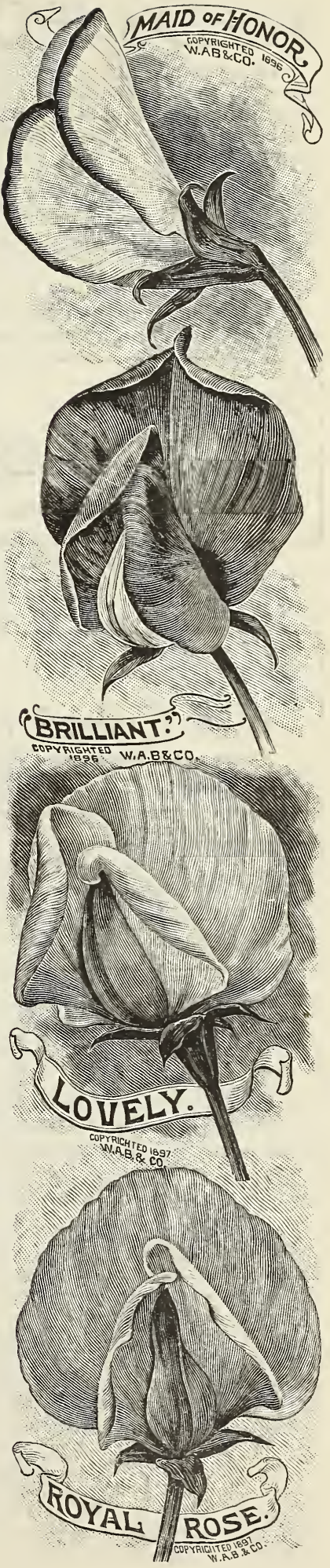


In the United States, among a population of seventy millions, there are, of course, many who seek for "Bargains" in seeds as well as other merchandise. In order to show the difference in QUALITY between BURPEE'S and the "Cheap Seeds" so largely advertised, we offer these POPULAR COLLECTIONS, at twenty-five cents each, which give as much for the money as can be obtained anywhere, while the quality is the BEST.

Is is only by growing these varieties in large areas, and by sacrificing all profit for the sake of introducing BURPEE'S SEEDS to thousands of new customers, that we can afford to make these unequaled offers. The packets are each of full size, and the quality the same as if purchased at regular retail prices. We cannot allow any changes to be made, as these Collections of "SEEDS for the MILLION" are packed in advance,thereby giving work to many enployees for some months before the busy season begins.

To show not only that BURPEE'S SEEDS are the Best that Grow, but also that the vegetables of our own introduction are unequaled, we prepared this special Collection for 1898 .

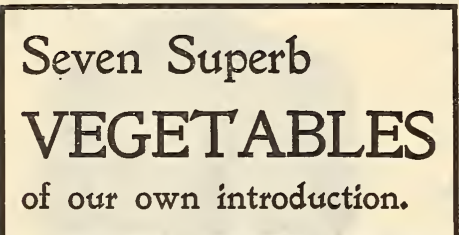

For $25 \mathrm{Cts}$, we will mail to any address in the each of the long-kited States one regular-size packet on page 15,-the delicious NEW GOLDEN EAGLE MELON, illustrated on page 12,-the quick-growing NEw RuBy PEARL RADISH, illustrated on page 20 , - the true dark STINSON BEET,- the famous BURPEE'S AlLHEAD EARLY CABBAGE, offered on page 6 ,- - the hardheading ICEBERG LETTUCE, illustrated on page 10,-and the famous Matchless TOMATO.

ACS All seven packets will be mailed for twenty=five cents, with illustration and directions for culture printed upon each packet.

Six of these Collections, or any other twenty-five-cent Collection, will be mailed for one dollar net, in accordance with our offer on second page cover, by which the purchaser is entitled to select fifty cents' worth extra for each one dollar's worth of seeds in our retail packets.

\section{Burpee's GEM Collection of FLOWERS.}

For $25 \mathrm{Cts}_{\text {s }}$ we mail one full-size packet each of Ten Beautiful Annual Flowers, embracing the Little Gem Sweet Alyssum,-Fordhook Favorite Asters, - New Double Centaurea,-Reselected Dianthus chinensis,-Fordhook Finest Mignonettes, -Nicotiana affinis,-Starred and Fringed Plilox Drummondii,-Poppies (Fordhook Fairies),-Mammoth Fancy Cosmos, -and the Mammoth Fordhook Famous Verbenas.

Never before has Burpee's GEM Collection contained such a fine assortment, - see advertisement on page 96 of BURPEE's FARM ANNUAL FOR 1898. At retail prices these ten packets would cost one dollar, but the collection is sold for twenty=five cents.

\section{Seven Superb Sweet Peas.}

\section{Collection of Nasturtiums.}

For $25 \mathrm{Cts}$. we will mail one packet each of Burpee's Brilliant,CI. Coquette,-Burpee's New Countess, - Prima Donna,the colored plate in BURPEE'S FARM ANNUAL FOR 1898; also a large packet of the most beautiful New American Seedlings. It would have cost more than two dollars to have purchased these new varieties last year, while even at our Special low prices for 1898 , purchased separately, these seven packets would now cost fifty cents at retail.

\section{Five Pansies for $25 \mathrm{Cts}$.}

For $25 \mathrm{Cts}$, as advertised on page 92 of BURPEE's FARM For 25 CtS., ANNUAL, this Collection gives more than trio ounces of the seed. It contains one package each of the gorgeous New Tom Thumb Mixture, the new climbing Hybrids of Madame Gunter; onehalf ounce of Mixed Tom Thumb, one ounce Tall Nasturtiums, Mixed, and one-half ounce of the superb Fordhook Favorite Climbing Nastur= tiums, - all of which, if purchased separately, would cost fifty-five cents. With each Collection we enclose a circular giving directions for culturc.

As advertised on page 93 of BuRPEE's FARM ANNUAL FOR 1898, we will mail one regular packet each of Emperor Frederick,-Meteor,-Peacock, - Spectabilis, - and Burpee's Giant Defiance, Mixed. If purchased outside of this Collection, these five packets would cost fifty-five cents. Those who know the value of choice Pansy seed, will fully appreciate the liberality of this offer, when we state that it gives more than four hundred seeds for twenty-five cents. In the envelope containing each collection we enclose our printed directions, "How to Grow the Largest and Finest Pansies." FOR ONE DOLLAR we will mail ALL THE ABOVE or ANY Five AND, as a premium, give FREE one full-size packet (price 25 cts.) of either The Grand New Dwarf Sweet Pea,_-Burpee's PINK Cupid,-or the magnificent New Giant= Flowered Pansy,-PRESIDENT McKINLEY, our exclusive novelty. For two dollars you can have any ten Collections that you may select and both premiums of the Pansy and Cupid.

\section{A GETTS who wish to make a business of selling these collections will be supplied AGENTS who wish to make a business of selling these collection, but this wholesale price, of eourse, does not inelude BURPEE'S PINK CUPID or any other premium. Ales By express or freight, we supply all these Collections wholesale at is cts. each or $\$ 1.80$ per dozen.}


ORDER SHEET for SEEDS, BULBS, and PLANTS.

\section{W. Atlee Burpee \& Co., Philadelphia, Pa.}

State here whether wanted by MAIL, EXPRESS, OR FREIGHT.

Date, 1898.

Name,

Post Office,

County,

State,

Express Office,

AMOUNT ENCLOSED.

SPECIAL NOTICE. The prices given in our WHOLESALE PRICE LIST for MARKET GARDENERS do not include cost of tranportation. The purchaser pays freight or express charges upon receipt. IF SEEDS ARE ORDERED TO BE SENT BY MAIL, the cost of postage (2 OUNCES FOR ONE CENT, 8 CENTS PER POUND) must be sent with order. Peas and Beans cost 15 CENTS PER QUART and Sweet Corn 10 CENTS PER QUART, postage.

It is easy to order Seeds by MAIL. All you have to do, is to make out a list of the seeds wanted, attach the prices to each, deducting one=third from the total of seeds in retail packets, and remit by money order, draft, or registered letter. We assume all risk, - that is, we guarantee that the seed will arrive promptly and in good condition.

NAMES OF SEEDS ORDERED.

PRICE. 


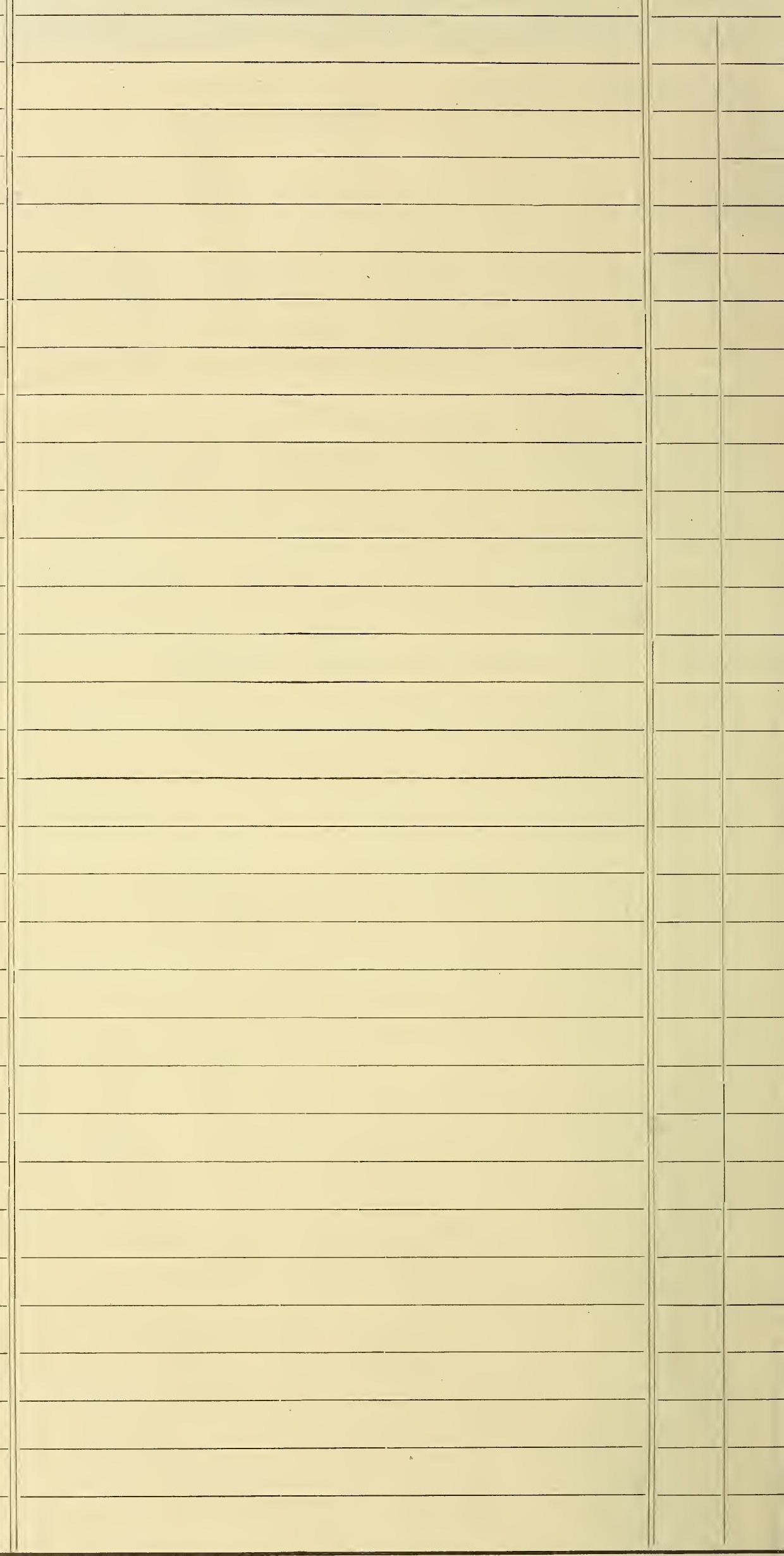

\section{BURPEE'S SEEDS GROW and are famous for the Uniform Excellence of their Products}

PLEASE WRITE each item of your order on a separate line, and carry out the prices. Also please keep a copy of your order, with which to "check off" the seeds when received, to be sure that you receive just what you ordered. We seldom make mistakes, but when we do, want to be notified immediately, so that they can be corrected.

Kindly write any questions, requiring answer, separately from the order 


\section{NOVELTIES IN VEGETABLES.}

In the twenty-two years that we have been engaged in the business, we have introduced more NOVELTIES of permanent value than any other seed growers in America. It is, unfortunately, true that the majority of so-called "Novelties" are short-lived. While old varieties are sometimes re-named, for the purpose of deceiving, the main reason is that the introducers, not having facilities for comparison, do not know that there are already in cultivation varieties of similar type, and perhaps of superior quality. We make it a rule to recommend Novelties only of our own knowledge, and discard annually more than we introduce. Thus, planters generally have learned that absolute confidence can be placed in our descriptions.

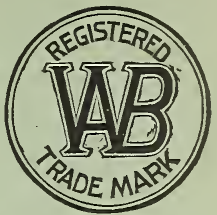

For 1898 we offer twenty=one Grand NOVELTIES in Vegetables

For full descriptions and illustrations you should read our new book of 144 pages, BURPEE's FARM ANNUAL For 1898,-known as "The Leading American Seed Catalogue."

\section{Burpee's FORDHOOK FANCY Tomato.}

While unlike any other variety known, this is more

than a novelty, - a genuine good market tomato.

The fruit is of large size, very solid, with but NOTE.-This is the best of many new few seeds, of a rich ruby-red color and delicious flavor. The handsome, smooth fruits are borne in clus- $\quad$ pert, Mr. E. G. GREEN, formerly of THE ters of three and four, at every other joint, and as the joints are should be given him. for having originated close together, the plant presents a very crowded appearance. Small plants, pruned to $a$ single stem only, two and a half feet high, have produced four to fire pounds of fruit.

From the appearance of the first leaves the plant resembles that of a potato-in fact, it might be called

The Potato=Leaf BUSH Tomato.

It is so compact and erect in growth that no stakes are required. Even the side branches grow upright, and hence more plants can be set to a given area than of any other variety,-making it easily the most productive good tomato in cultivation.

THE FORDHOOK

FANCY will become immensely popular, both in the home garden and for shipping to market. The large solid fruits are always smooth and handsome, while the skin is not easily broken. In fine quality, compact, bushy growth, and immense productiveness it far surpasses the Dwarf Champion and Dwarf Aristocrat and will prove valuable also for forcing.

The stock of seed is very limited and we must decline positively to supply more than fire packets to any one purchaser, for his own planting. Per small pkt. (of fifty seeds) $25 \mathrm{cts}$. That all may try this most remarkable New Tomato, we offer still smaller packets at 10 cts.,-each containing twenty seeds.

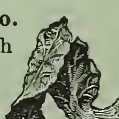
so distinct and valuable a variety.

On Nov. 17, 1897, Mr. Green wrote us: "It is certainly unique in foliage. This fall, when weeding strawberries, I found what $I$ was sure was a potato, and not until I dug it
up and smelled of the leares did I know it 1. 1 up and smelled of th" 

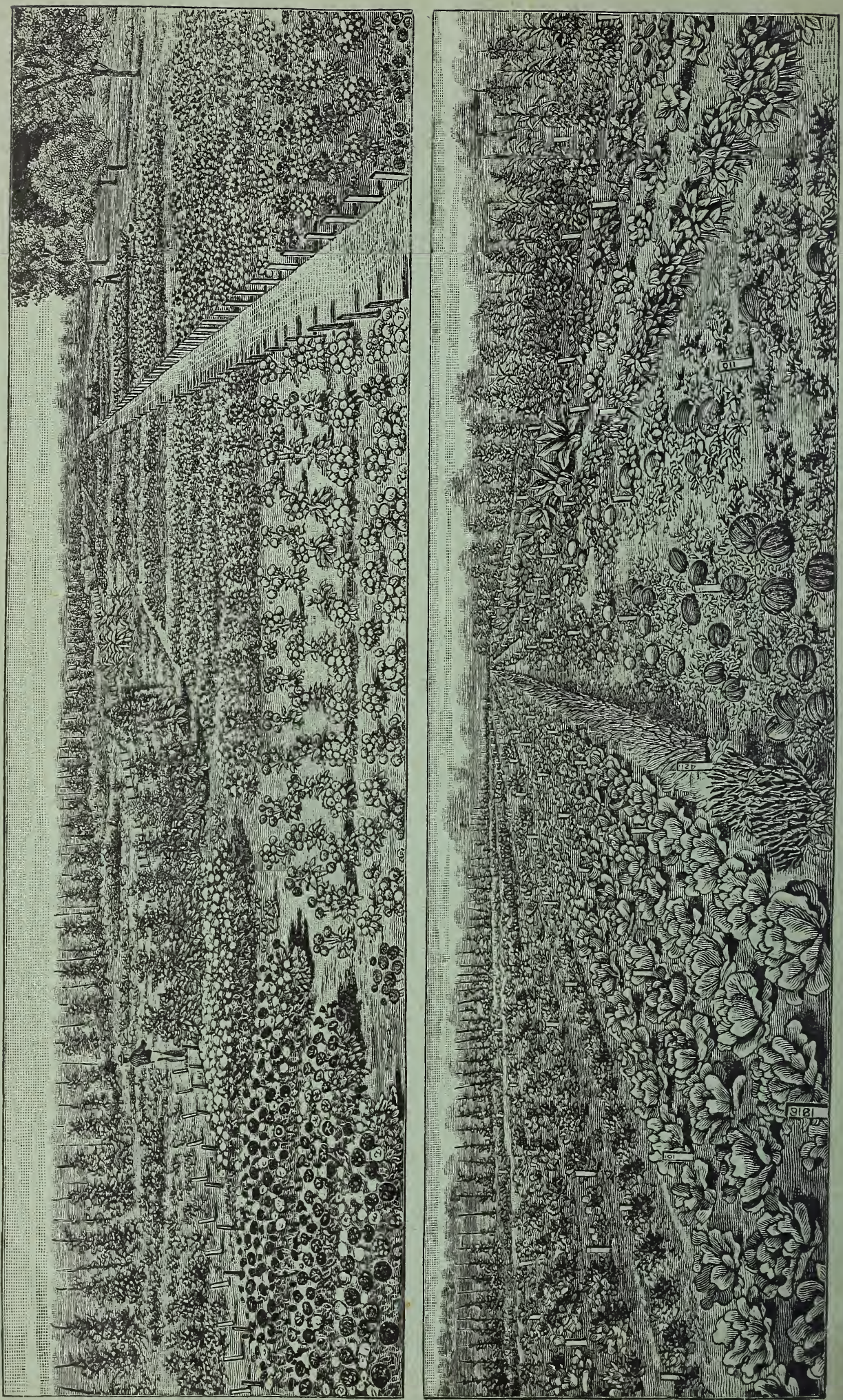
2. 14. 4r. 2. 6. 2N (1) 6.7. HeH.

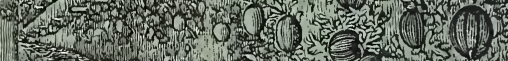

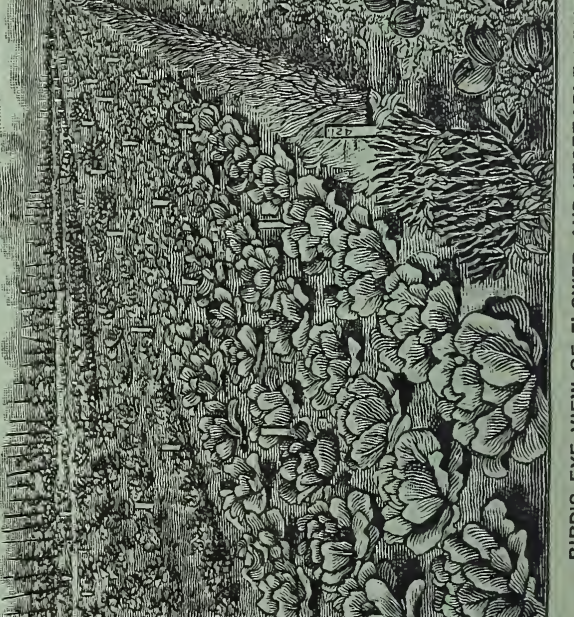

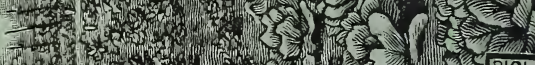

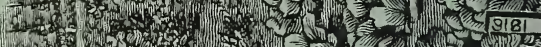
17) 3.

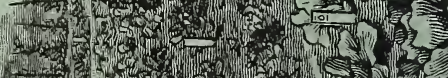

